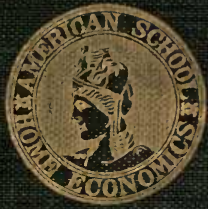





\section{STATE NORMAL SCHOOL LOS ANGELES, CALIFORNIA}

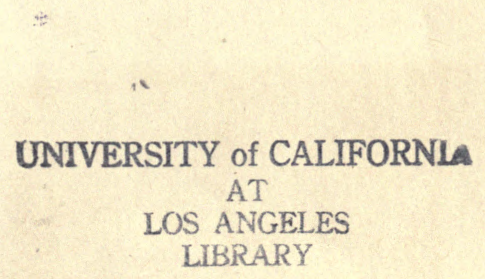





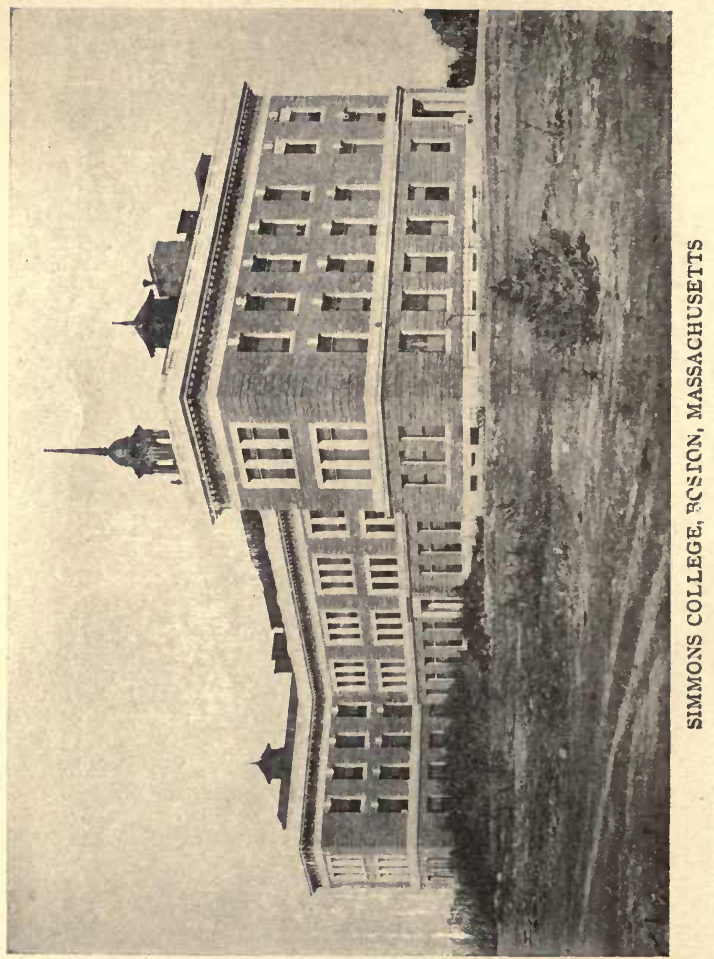




\section{THE - LIBRARY}

$\mathrm{OF}$

\section{HOME ECONOMICS}

A COMPLETE HOME-STUDY COURSE

ON THE NEW PROFESSION OF HONE-MAKING AND ART OF RIGHT LIVING; THE PRACTICAL APPLICATION OF THE MOST RECENT ADVANCES

IN THE ARTS AND SCIENCES TO HOME AND HEALTH

\section{PREPARED BY TEACHERS OF RECOGNIZED AUTHORITY}

FOR HOME MAKERS, MOTHRRS, TEACHERS, PHYSICIANS, NURSES, DIETITIANS, PROFESSIONAL HOUSE MANAGERS, AND ALL INTERESTED

IN HOME, HEALTH, ECONOMY AND CHILDREN

\section{TWELVE VOLUMES}

NEARLY THREE THOUSAND PAGES, ONE THOUSAND ILLUSTRATIONS

TESTED BY USE IN CORRESPONDENCE INSTRUCTION REVISED AND SUPPLEMENTED

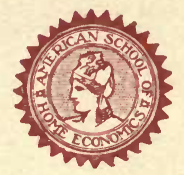

C.HICAGO

A MERICAN SCHOOL OF HOME ECONOMICS 1911

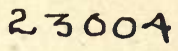




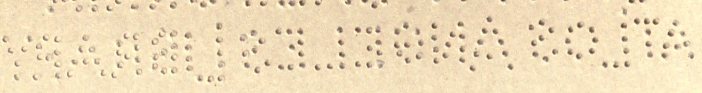

Copyrigh'r, 1907

B Y

Home ECoNomics Associatron

Entered at Stationers' Hall, London

All Rights Reserved 
DEDICATED TO

MRS. HELEN C. KIMBERLY

WHOSE INTEREST IN THE EDUCATION OF THE HOME-MAKER AND WHOSE ENCOURAGEMENT AND ASSISTANCE

HAVE HELPED TO MAKE POSSIBLE

THE LIBRARY OF HOME ECONOMICS 



\section{AUTHORS}

ISABEL BEVIER, Ph. M.

Professor of Household Science, University of Illinois. Author U.S. Government Bulletins, "Development of the Home Economics Movement in America," etc.

\section{ALICE PELOUBET NORTON, M. A.}

Assistant Professor of Home Economics, School of Education, Univer itv of Chicago; Ditectur of the Chautauqua School of Domestic Science.

\section{S. MARIA ELLIOTT}

Instructor in Home Econoınics. Simmons College; Formerly Instruc tor School.ol Housekeeping, Boston.

\section{A.NNA BARROWS}

Director Chautauqua School of Cookery; Lecturer Teachers' College. Columbia University, and Simmons College; formerly Editor "Ameri cun Kitcben Magazine;" Author "Home Science Cook Book."

\section{ALFRED CLEVELAND COTTON, A. M., M. D.}

Prolessor Diseases of Children, Rush Medical College, University of Chicago: Visiting Physician Presbjterian Hospital, Chicago; Author ot "Diseases of Cliildren."

BERTHA M. TERRILL, A. B.

Professor in Home Economics in Hartforu scnool of Pedagogy ; Author u[ U.S. Government Bulletins.

\section{KATE HEINTZ WATSON}

Formerly Instructor in Domestic Economy, Lewis Institute : Lecturer Uni.ersity ot Ch.cago.

\section{MARION FOSTER WASHBURNE}

Editor "The Mothers' Magazine;" Lecturer Chicago Froebel Association; Author "Everyday Essays," "Family Secrets," etc.

\section{MARGARET E. DODD}

Graduate Massachusetts Institute ol Technology ; Teacher of Science, Woodward Institute.

\section{AMY ELIZABETH POPE}

With the Panama Canal Commission ; Formerly Instructor in Practical and Theoretical Nursing, Training School lor Nurses, Presbyterian Hospital, New York City.

\section{MAURICE LE BOSQUET, S. B.}

Director American School of Home Economics: Member American Fublic Healtb Association and American Chemical Society. 


\section{CONTRIBUTORS AND EDITORS}

\section{ELLEN II. RICHARDS}

A uthor "Cost of Food," " Cost of Living," "Cost of Shelter," " Food Materials and Iheir Adulteration," etc., etc.; Chairman Lake Placid Conference on Home Economics.

\section{MARY HINMAN ABEL}

A uthor of U.S. Government Pulletins, "Practical Sanitary and Economic Cooking," "Sale Food," etc.

THOMAS D. WOOD, M. D.

Professor of Physical Education, Columbia University.

H. M. LUFKIN, M. D.

Professor of Physical Diagnosis and Clinical Medicine University of Minnesota.

OTTO FOLIN, Ph. D.

Spscial Investigator, McLean Hospital, Waverly, Mass.

T. MITCHELL PRUDDEN, M. D., LL. D.

Author "Dust and lts Dangers " "The Story of the Bacteria," "Drink. ing Water aud Ice suppl es," etc.

FRANK CHOUTEAU BROWN

Architect, Boston. Mass.; Author ct "The Five Orders of Architec ture," "Letters and Lettering."

MRS. MELVIL DEWEY

Secretary Lake Placid Conlerence on Home Economics.

HELEN LOUISE JOHNSON

Frofessor of Home Economics, James Millikan University, Decatur.

FRANK W. ALLIN, M. D.

Insıructor Rush Medical College, University of Chicago.

\section{MANAGING EDITOR}

MAURICE LE BOSQUET, S. B.

Director American School of Home Economics. 


\section{BOARD OF TRUSTEES}

OF THE AMERICAN SCHOOL OF HOME ECONOMICS

MRS. ARTHUR COURTENAY NEVILLE

President of the Board.

\section{MISS MARIA PARLOA}

Founder of the first Cooking School in Boston; $\mathrm{Au}$ ' hor of "Home Economics," "Young Housekeeper," U.S. Government Bulletins, etc.

\section{MRS. MARY HINMAN ABEL}

Co-worker in the "New England Kitchen," and the "Rumford Food Laboratory;" Author of U. S. Government Bulietıns. " I'ractical Sanitary and Economic Cooking," etc.

\section{MISS ALICE RAVENHILL}

Special Commissioner sent by the British Government to report on the Schools of Home Economics in the United States, Fellow of the Royal Sanitary Institute, London.

\section{MRS. ELLEN M. HENROTIN}

Honorary President General Federation of Woman's Clubs.

\section{MRS. FREDERIC W. SCHOFF}

President National Congress of Mothers.

\section{MRS. LINDA HULL LARNED}

Past President National Household Economics Association; Author ol "Hostess of To-day."

\section{MRS. WALTER McNAB MILLER}

Chairman of the Pure Food Committee of the General Federation of Woman's Clubs.

\section{MRS. J. A. KIMBERLY}

Vice President of National Household Economics Association.

\section{MRS. JOHN HOODLESS}

- Government Sunerintendent of Domestic Science for the province of

- Ontarin: Founder ()ntario Nurmal School of Domestic Science, now the M..cDonald Institute. 



\section{FOREWORD}

HE Library of Home Economics is the resuit of some years' experience in teaching by correspondence what may be termed the "New Profession of Home Making," and what Mrs. Ellen H. Richards has called the fourth " $R$ " in education-Right Living.

I It is realized that the business of housekeeping has not kept pace with the tremendous advancement in other lines of human endeavor, that the wonderful discoveries in science and developments in the arts only slowly and partially have been applied to the problems of personal health and home life.

I With the object of giving home-makers and mothers, everywhere, some of the benefits of the teaching now offered in a number of colleges under the terms, domestic science and home economics, the correspondence courses of the American School of Home Economics were planned. Special lesson papers or text books were necessary, for ordinary text books are not adapted to correspondence instruction. From some years of experience in correspondence teaching in other lines, it was known that the lesson books, to be successful, must be simple, concise, non-technical, and above all sufficiently interesting and of immediate practical value to hold the attention of the student throughout the course.

9 The aim has been, not to teach science nor to teach 
theory, as such, but rather the best scientific practice with sufficient theory to shew the reason "why" for such practice; in a word, to give as much real help and practical information as possible.

9 After much planning and consultation, well known teachers were invited to prepare the lesson books from the standpoint of the average woman, and later these same teachers have given or supervised the correspondence instruction. The whole course is so planned that each series of lessons fits into and supplements the others, making one logical whole, without duplication.

g From the expressed appreciation of nearly two thousand students, the results sought would seem to have been attained. The scientific accuracy and scholarly tone of the books is attested by their use as text books in many prominent schools and colleges. Although prepared primarily for the woman in the home, as the books naturally embody the teaching experience of their authors they have been found especially valuable to teachers aro to those preparing themselves for various positions.

g The Library contains the complete series of iessons, including test questions, which the active members of the School answer in writing and send in, as a written recitation, for the correction and comment of the teachers. This correspondence work has given the text a most rigorous and effective test for clearness of statement and adaptability. In republishing the lessons for the Library such revisions have been made as seemed necessary to clear up all obscure points and to rectify original deficiencies.

9 In addition, much supplementary material of interest 
has been added by the authors, based on the:r experience in correspondence instruction. A number of special articles of importance are also included.

प At the back of each volume will be found a program or outline for supplemental study, making virtually an extension of each series of lessons. These are arranged primarily for classes taking up courses with the School by the group plan, but they should prove of equal value to the individual student and be very suggestive to teachers. The reference books mentioned and the small amount of apparatus required when experiments are suggested are loaned to members of the School when not available locally.

In place of prefaces to the volumes, reproductions are given of the introductory letters of the instructors which are sent to students when each new subject is begun.

IThe Library is published to give the members of the School their course of study in permanent form, with indexes for ready reference, and in binding worthy of the contents. It will also serve as a reading course for associate members of the School and will be available as a general reference work, making the public acquainted with the character and merit of the correspondence courses of the American School of Home Economics.

$\Psi_{\text {It }}$ is in hope that it may serve as an inspiration and an authoritative guide for inexperienced home-makers; that it may open up a new world of interest to the expe-ienced home-maker and give added meaning and importance to familiar tasks; that it may, in some measure, increase health and happiness, that the Library of Home Economics is offered. 



\section{VOLUMES}

I The House: Its Plan, Decoration and Cark

II Household Bacteriology

III Household Hygiene

IV Chemistry of the Household

Y Principles of Cookery

VI Food and Dietetics

VII Household Management

vili Personal Hygiene

iX Hone Care of the Sick

$\mathrm{X}$ Textiles and Clothing

XI Study óf Child Life

- XII Care of Children 


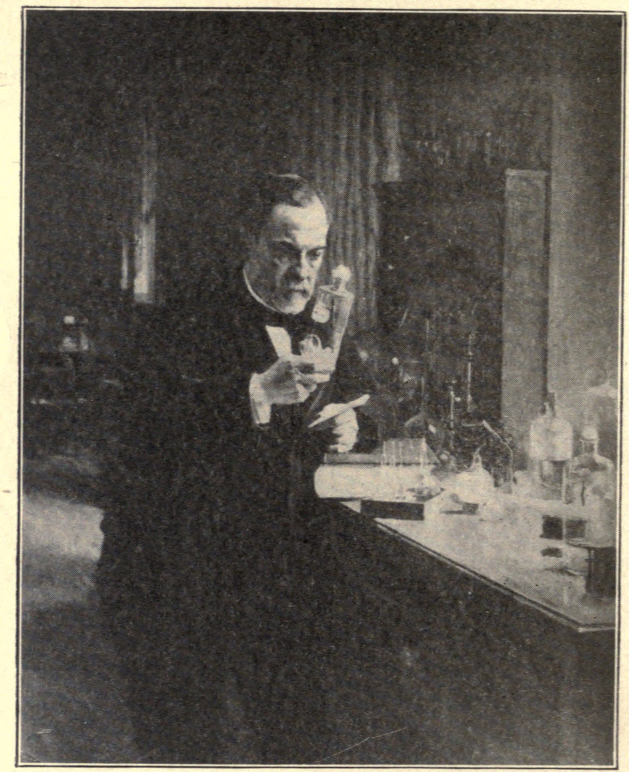

LOUIS PASTEUR. FATHER OF BACTERIOLOGY 


\section{Household Bacteriology}

BY

S. MARIA ELLIOTT

INSTRUCTOR IN HOUSEHOLD ECONOMICS

SIMMONS COLLEGE, BOSTON

23004

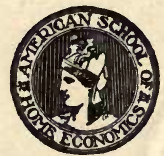

CHICAGO

AMERICAN SCHOOL OF HOME ECONOMICS

230004 
COPYRIGHT, 1904, BY

AMERICAN SCHOOL OF HOUSEHOLD ECONOMICS

COPYRIGHT, I906, 1910, BY

HOME ECONOMICS ASSOCIATION

Entered at Stationers Hall, London

All Rights Reserved 


\section{QR 56 \\ E46h}

\section{CONTENTS}

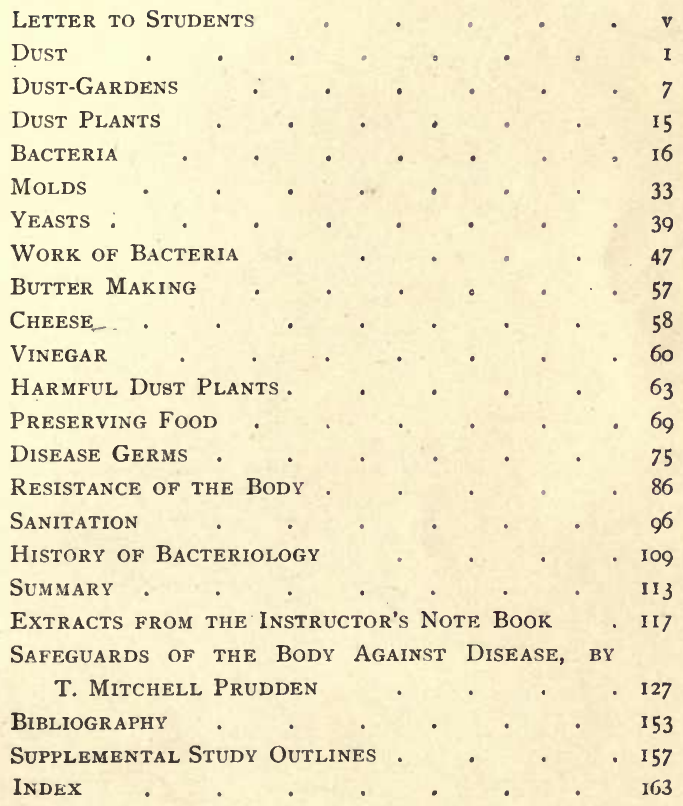



AMERICAN SCHOOL OF HOME ECONOMICS

CHICAOO

January, 1, 1907.

My dear Madam:

In beginning our work in Househola Bacteriology together I should like to make a fer suggestions as to aims and methods of study.

The aims to be reached in the study of any science are at least two--a knowledge of its underlying principles and as thorough an application of those principles as is possible.

For the principles you will consult the lesson booklets. Frcm them, too, you will got suggested applications, but the subject will not become $a$. part of yourself until you recognize new applications many times a day. It is said that no person KNOWS a foreign languge until he can think in that language. In \& similar way you will want to think these facts into your life and work.

Suggestions for study have already been given to you. I hope that you may be able to try all of the experiments suggested; at least make a "dust garden" as described. If you can get no suitable dish, a regular Petri dish may be obtained through the School fur 30 cents and a tube of prepared "nutrient gelatine" for 20 cents. The dish may. be returned. Also, I hope that you will read some of the books recomended in the bibliography.

The facts of bacteriology underlie so t'irmly all our daily living that there is no need to go far afield for illustrations. But a thorough knowledge of the science can be gained only through laboratory methods and with a microscope. Therefore, I hope you may be able sometime to supple- 
ment this study by microscopic work. Perhaps through the aid or some doctor or other scientist you may be able now to get a peep into this world of the unseen.

If these les'sons point out dangers of which you were before unconscious, they also suggest ways of escape from those dangers. You will gain some knowledge of the causez of waste and disease If this leads you to efforts for the prevention and removal of such causes, the result will be those healthful conditions which make the most effectual safeguard against the attacks of the few micro-organizms that are our foes.

I hope the relations between hygiene and some of the daily tasks of housekeeping will gain a deeper signiticance in your mind: and this elementary study may result not only in pleasure and profit to you, but also, through you, in better conditions of healthful living for others.

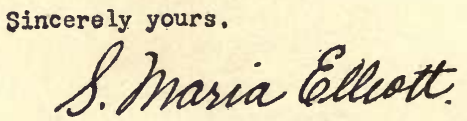

Instructor 



\section{TRmentlier!}

THAT ten billions of dollars are expended annually in the United States for food, clothing, and shelter - with greater knowledge and efficiency, better satisfaction could be obtained and one billion dollars saved for higher things.

THAT half a million lives are cut short and five million people 1 are made ill by "preventable" diseases every year - with universal knowledge of hygiene and sanitation nearly all deaths and illness from such causes could be prevented.

THAT six hundred thousand infants under two years end their

1 little span of life yearly, while millions of children fail to reach their best physical development because their mothers and fathers understand not how to care for them in the light of science-with more knowledge at least half the number of babies could be saved and the physical standard raised immeasurably.

THAT thousands of homes are wrecked, tens of thousands of lives are ruined, and hundreds of thousands are made unhappy because the home-keepers of our country have no training in the greatest of all professions, the "profession of homemaking and motherhood"-only through such education can present domestic difficulties be solved and the modern home contribute all that it should to happiness and well being.

THAT all must live in some sort of a home-that everyone finds his chief happiness there - that character is developed there - that no great advance, spiritual or material, is possible which does not begin with the home - that the home-makers of America have the making of the nation.

THAT on the breadth and strength of the base depends the height of a pinnacle - on the home foundation we rear the pinnacle of all that is good in state or individual.

- American School of Home Economics 


\section{HOUSEHOLD BACTERIOLOGY}

\section{4}

MOST persons now know that mankind is greatly 1 troubled by the work of certain minute agents -variously termed germs, bacteria, micro-organisms. Few, however, realize the good that these forms do, or understand them and their place in the world. It is the purpose of the following pages to show the relations, both good and evil, that bacteria and other micro-organisms bear to the household.

\section{DUST}

Most housewives look upon dust as an undesirable thing that they are constantly seeking to be rid of. If Prevalence of Dust dust is seen on the piano or on the table each thinks she will be considered a slack housekeeper. Perhaps some are not troubled by the presence of dust that does not show. Such fight the enemy vigorously where visible, but relax effort where or when he is invisible. The temptation comes to hide the tell-tale dust by shutting out light.

Few persons there are who have not at some time 
exclaimed, "Where does all the dust come from?" If a house be thoroughly cleaned from cellar floor to attic ridge, tightly closed for months or years, when reopened dust will be found in great quantities. -

This is true even in the country, where perhaps a single house, removed from the highway, stands surrounded by grass and trees.

The "housekeeping" of ships includes dusting. The officers' quarters of the government ships are dusted regularly, although land may not be seen for months at a time.

Dust-proof

Room or House

Scientists have tried to get a dust-proof room or house in which to carry on their experiments. This has required attention to location and site, that there should be no jar from traffic or vibration from winds; a careful preparation of the surrounding soil ; numerous walls separated from each other and made largely of glass, carefully joined and hermetically sealed. The air admitted must be freed from its dust; all clothes ordinarily worn by the experimenter must be exchanged for garments especially prepared and cared for, before he enters this to-be-dustless room. Even then all surfaces need to be slightly moist, that any stray speck of dust which has escaped all these gurards may be caught and held.

Such conditions as these can never be secured in ordinary life, so that dust will probably be present with us always. Indeed, it is probable that were all dust exterminated, life also would become extinct, for life in its most efficient forms needs light, and Tyndall 
proved by delicate experiments that when all dust was removed from the track of a beam of light, there was darkness. So before the command, "Let there be light," the dust condition of light must have been present. Balloonists find that as they ascend higher the color of the sky deepens. At a distance of some miles the sky is nearly black, there is so little dust to scatter the rays of light. If the stellar spaces are dustless, they must be black, and therefore colorless. The moisture of the air collects about the dust-particles, giving us clouds, and with them all the glories of sunrise and sunset. Fogs, too, are considered to be masses of "water-dust," and ships far out at sea have had their sails colored by this dust while sailing through banks of fog.

Astronomers find meteoric dust in the atmosphere. When this falls on the snow and ice fields of the Arctic Meteorio Dust regions it is readily recognized. The eruption of Krakatoa proved that volcanic dust is disseminated worldwide.

An old writer has said: "The sun discovers atomes though they be invisible by candle light, and makes them dance naked in his beams."

Thus dust, just common every-day dust, is a very important and complex substance, which promises much of interest in its study. Therefore, again we ask where does it come from and of what is it made?

When a March wind blows over a sandy road or a November gale sweeps through city streets, it is evident that a large part of the dust found in the house 
Ingredients of Dust

comes through open doors and windows. Few windows and doors are so tightly fitted that fine dust will not sift in round their casings.

Until electricity is made the common source of heat and light, there will be much dust from coal and wood, both before and after they are burned. These sources are too evident to need more than a mention. It is from the wear and tear of the house itself, its finish and furnishings, from our own bodies and the clothing that covers them, that the larger amount of dust comes. From these we have bits of wood, stone, cotton, hair, dead cells from all animal bodies-a mass of mineral, animal, and vegetable matter of very complex composition.

Since time began, everything in this old world has thus been wearing away more or less slowly, adding bit by bit to similar accumulations, until what we know as soil has been built up-pure mineral soil made from the debris of the rocks; organic soil or loam from the addition to this mineral soil of vegetable and animal debris. The same processes are continually going on all about us.

The dictionaries recognize this process when they tell us that dust is "Earth or other matter in fine dry particles so attenuated that they can be raised and carried by the wind."

Movements of Dust

Winds then are the responsible agents for much of the dust in our houses, but wind is simply air in motion. We cannot walk across the floor, make a bed, rock comfortably in a chair, or dance a jig without 
making some wind currents. If dust is present in this current, it will be stirred up to settle back, where it was before, or to be blown to some other place. The more dust or the stronger the wind, the surer it is that the dust will be carried along with the current.

But why should the housewife spend so much energy and time in trying to keep her house free from dust? Why Reen Free From: All the dust elements we have seen so far are not likely to do her much harm. The ashes or other mineral dust may scratch the polished table or the brass ornaments and silverware, but not sg long as it lies quiet. It is the moving grain of sand, not the still one, that scratches. The other ingredients, bits of dead animal or vegetable matter, may be disagreeable to think of, but they are of the same stuff as ourselves, our clothes, our furniture. If this dead matter were all there is to dust, no one would ever have heard of the science of bacteriology.

Many of the daily occurrences in the home give rise to questions which may be readily answered if we Familiar
Experiencet will but turn our kitchens into laboratories and try some simple experiments.

Perhaps you forgot to change the water in a vase of flowers and it stayed there a week. How did it smell when you poured it out? How did the stems that had been in the dirty water feel?

Possibly when you left home for a week's visit last summer, you knew the ice was all gone from the refrigerator, but you forgot to empty the pan underneath. 
What did you find on your return? A slimy film oves the surface of the water, did you not?

Such experiences may be familiar to all. A few years ago these changes were thought to be due to the oxygen of the air, which in some way, under certain conditions, made some things sour, some bitter, and others putrid.

Eeavened

Bread

In the days of our grandmothers much of the bread was made with leaven like that used in Bible times-a mixture of flour and water exposed to the air and whatever the air contained. This, was called "barm." Such bread is still common in some parts of our country, and known as "salt-rising bread," and the barm when made with milk is called "milk emptins."

In the old days a portion of the leavened mass was kept to start the next batch of bread. Occasionally this was forgotten or it spoiled, then the housewife borrowed from her neighbor, as when the fire on the hearth was out, a coal was borrowed. Sometimes now the yeast raised sponge becomes slightly sour before it is ready for baking. Why?

Apple or other sauces containing sugar ferment or sour and the housewife scalds them. This may make them as palatable as when freshly stewed. Yet they often turn sour again and, after a while, scalding or even boiling does not remove the sharp or stinging effect upon the tongue.

The moist bread in the jar is found specked with mold; some August morning the sprinkled clothes 
in the laundry basket are mildewed; the "best room," seldom used and darkened by drawn shades and tightly closed blinds, becomes musty.

What do all these things mean, or have they any relation to each other?

We will now see if we can answer these questions.

Experiment I. Mix a little yeast with some sweetened water and let it stand in a warm place where the temperature is from $70^{\circ}$ to $75^{\circ} \mathrm{Fahr}$. Put a few tablespoonfuls of beef broth or molasses water into a cup or bottle and leave it uncovered in the kitchen where it will be warm. Watch carefully what happens. Before long bubbles show on the surface of the sweetened water; perhaps you may see bubbles rising in the broth. If left long enough the sweet liquid will be sour and the good broth smell bad. You say the one has fermented, the other is putrid. What has made the change? You did not add anything to the mixture; you only kept it warm and uncovered.

\section{DUST GARDENS.}

Experiment II. From any dealer in laboratory supplies or through the doctor or druggist get a Petri dish or plate. This is simply two round glass dishes, onequarter to one-half inch in depth, one just large enough to fit over the other as a cover. See Fig. I. This experiment can be made without the Petri dish, although not so conveniently, as follows :

Take a clear glass sauce dish or a finger bowl. Fig. 2. Cover with a piece of smooth, thin glass clear

Experiments with Dust 
enough to see through readily and large enough to entirely and tightly cover the dish. After washing well, place both together in a pan in a cool oven and gradually raise the temperature until it is hot enough to bake bread or to yellow a piece of white paper in half a minute. Let them bake for an hour or more. Then open the oven and place the pan where the dish may cool slowly. When cold take out, without removing the covering plate, and put round both dish and plate a strong rubber band, or tie them together with a string.

This we will call our garden-plot. But a garden is of little use without something growing in it, and for this soil is required.

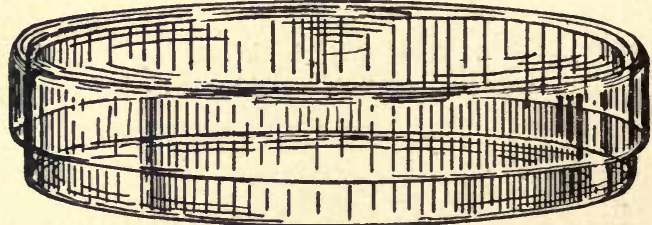

FIG. 1. PETRI DISH FOR PLATE CULTURES.

Soil for the Dust-Garden:
For the soil take the following recipe: Chop finely one-quarter pound of lean, juicy beef. Mix this with one cup of warm water. Heat in double boiler, stirring often until water in water pan has boiled fifteen min'tes. Remove inner dish, place directly over the fire and allow broth to boil ten or fifteen minutes. Clear by straining through two or more thicknesses of 
flannel wet in cold water. Squeeze the meat carefully to get out all its juices but not much fat. The meat is acid, therefore, add from one-eighth to one-quarter teaspoonful of bi-carbonate of soda. Replace the water lost through evaporation.

Moisten three heaping tablespoonfuls of finely divided gelatine in a very little cold water and add to

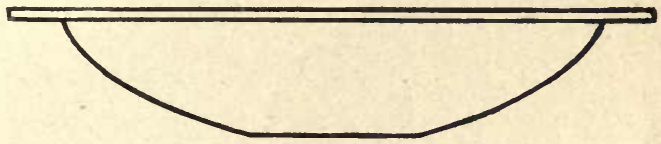

FIG. 2. SHALLOW BOWL COVERED WITH SHEET OF GLASS. the boiling hot broth. When the gelatine is dissolved, strain through hot flannel.

Put three or four tablespoonfuls of the broth into each of several small bottles. Plug the mouth of each with a close wad of cotton wool or tie over each a thick mat. of the same. For three successive days place the bottles on a piece of folded cloth in a pan of cold water and boil them fifteen minutes.

- Gelatine melts at quite a low temperature, so if the dust garden is prepared in summer it may not remain solid. If kept in a very warm place in the room it may melt at any time. A better substance to use for the jelly is agar, which remains solid at blood heat, $98.5^{\circ}$ Fahr. This may be found in some cities at the druggists', or at the dealers in chemical or bacteriological supplies. It solidifies suddenly, if its temperture drops below a certain point, and as it is rather 
difficult to prepare, the gelatine is more favorable for the amateur's use.*

In our garden we want only certain kinds of plants, and we want to know just where they come from, we,
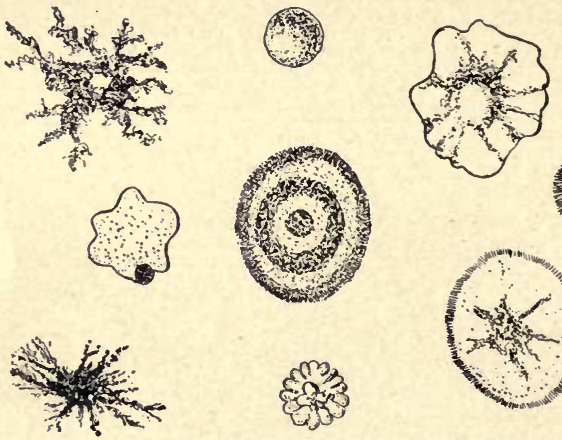

FIG. 3. COLONIES OF DUST-PLANTS, GROWN ON GELATINE. (After Conn. $f$ )

therefore, bake the dish and boil the jelly until sure that nothing in either is alive.

When ready to plant the garden, put the bottle of jellied beef juice into a dish of cold water. Heat this until the jelly is melted and then cool slightly.

*For the careful, accurate preparation of such soil, consult "Laboratory Work in Bacteriology," Frederick G. Novy, or any other manual of laboratory practice in Bacteriology.

A Petri dish may be obtained from the School for $30 \mathrm{c}$ and a bottle of agar ready for use for $24 \mathrm{c}$ (in stamps) sent postpaid.

†The "Story of Germ Life," H. W. Conn; D. Appleton \& Co., Publishers. 
Remove the elastic from the dish. When the tube or bottle of jelly is cool enough to be held in the hand, remove the cotton, wool plug, or stopper, carefully raise the cover of the dish on one side, just enough to insert the mouth of the bottle. Pour the melted jelly into the dish, cover, and gently iurn with a circular motion until the jelly is spread evenly over the bottom of the dish. Replace the elastic and let the jelly harden.

The garden is now ready for planting. To do this, all that is necessary is to remove the cover and leave the dish open for from twenty to thirty minutes. If opened in a very dusty place, expose only ten minutes. Do not go near or meddle in any way. At the end of the time replace the cover and the elastic band. Let the dish remain in a warm room not above $70^{\circ} \mathrm{F}$, and watch carefully for whatever happens.

In the course of thirty-six to forty-eight hours or longer, minute light-colored specks will show on the Growth of the Garden surface of the jelly. These will be seen to grow larger, to become of different colors-pink, yellow, orange, green, blue, possibly a deep red.

Some spots will be shiny, smooth, and round; others branched like mosses or seaweeds; others with white rims and dark centers, showing a pile like velvet, and, when seen through the sides of the dish, they may suggest minute pins with ball heads. Fig. 3 . All of these forms may not show themselves, but in most cases there will be seen the shiny, smooth spots, 
and the hairy or velvety ones. Look at the garden through a magnifying glass, if possible; watch every change; write down an accurate and full account as to time, appearance, conditions of temperature, light, etc. Then change the conditions. Put the dustgarden into the refrigerator, shut it into a box, etc. See how the colonies are affected by each new condition or by any two combined.

If a compound miscroscope can be used, touch the point of a needle to one of the spots and place the speck of matter taken up on a clean glass slide. Put on a drop of cool boiled water, and over this a cover glass; examine carefully for shape and motion; draw what is seen. In this way examine the different colonies to see if the forms in all are of the same shape.

Let the dust garden grow for a week or more, then gently raise the cover, smelling of the contents, and as this is done, if the growth is sufficiently far advanced, there will be sensible proof that dust-plants may cause putrefaction. The next time you are tempted to leave a piece of meat exposed, remember the dust-garden, and cover the meat with a cloth to keep out dust.

Figures 4 and 5 are photographs of such dust-gardens after more than two weeks' growth. The principal colonies of molds are marked $a$, and those marked $b$ are colonies of bacteria. In Fig. 5 the row of colonies marked $b^{\prime}$ shows well how thickly they 


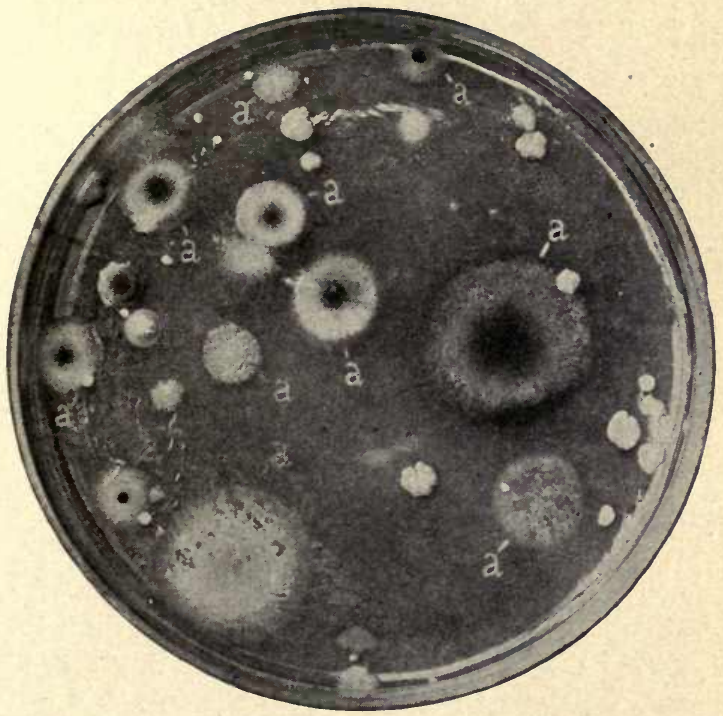

FIG. 4. PHOTOGRAPH OF A DUST GARDEN AFTER TWO WEEKS GROWTH.

Colonles of Mould Marked $a$; Colonies of Bacteria not Marked. 

sometimes crowd together. Probably these were all attached to some tiny fibre of wood or cloth.

The soil or "nutrient gelatine" in our experiments had beef juice in it; you will ask if any other soil would do. The gardener knows that his pinks will grow better in one place and his ferns in another because each requires or likes, we may say, a particular kind of food which that soil contains.

In the laboratoiy numerous soils or nutrient media are used-milk, potato, beer, blood-serum, etc.

A moment's thought will show that all the food substances which we like best are subject to changes which in general we designate as "spoiling." Some grow bitter, some sour, some odorous, some rancid. In a few cases this result is due to processes brought about by mere chemical changes-that is, without the intervention of any living agent or ferment; but in most cases where food spoils, it is due to the growth on or in the substance itself of the little plants, which have been carried to it through ordinary dust.

The milk in the pantry is found to be sour. When it was secreted by the milk gland in the cow's body it Souring was sweet and pure. It passed down into the milk duct in its passage outward, and here perhaps it met a few of the dust-plants which had passed into the mouth of the duct from the outside. Hundreds, no doubt, fell into the pail from the dusty air of the stall the cow's hairy coat, the milkman's clothes, or hands, or hair, even from the pail itself, for all are more 
or less dusty. Among these hundreds of forms are some that like the sugar of the milk as food. While feeding upon this, they change a part of it into acidlactic acid. When this acid reaches a certain amount, it coagulates the casein of the milk.

Production

The cleaner the milk, the fewer of these lactic acir producing plants will be present and the longer the milk will keep sweet. Cold retards their growth. Milk should then be cooled as quickly as possible after being drawn from the cow, and should be kept in a cold place at all times.

Milk is a most favorable culture ground for bacteria because it has some of all classes of food elements, being what is known as a perfect food. Its opaqueness hides much of the solid dirt which not only seeds it with bacteria but adds certain soluble matters. Too often the dirty character of the milk is known only by sight of the actual dirt at the bottom of the empty glass.

The possibilities in the way of clean milk, which means safe milk, were forcibly illustrated by exhibits from some American "model dairies" at the Paris Exposition in 1904. Milk and cream in a perfectly fresh condition were shown after a journey of ten days; the only treatment being extreme cleanliness in milking, stable, receptacle, etc., and cold. A glass of ordinary, unclean milk contains millions of bacteria, which although harmless to a vigorous adult are the cause, direct or indirect, of the death of thousands of young children annually. 


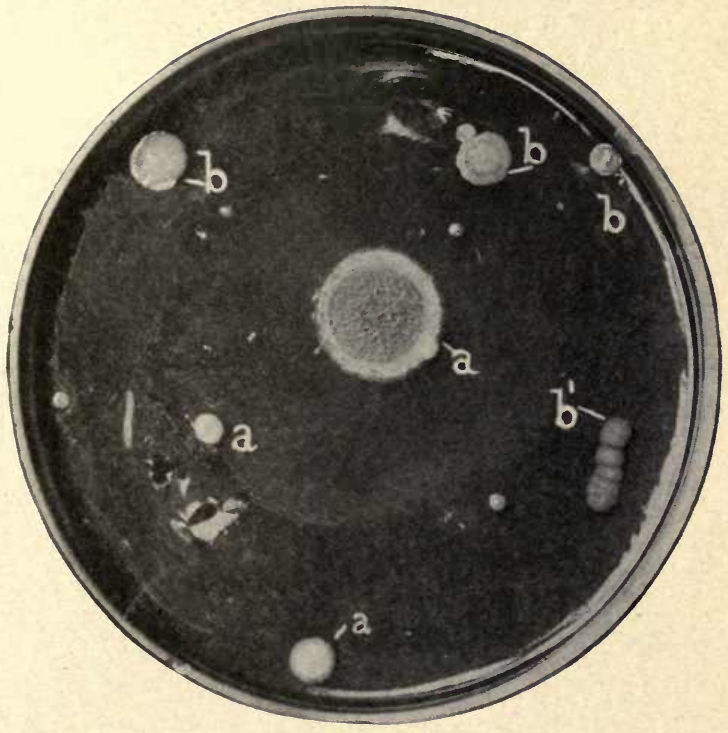

FIG. 5. A DUST GARDEN.

$\begin{array}{ll}\text { (a) Colonies of Mould. } & \text { (b) Colonies of Bacteria. }\end{array}$ (b') Colonies of Bacteria on a Thread. 



\section{DUST PLANTS}

We have seen from the dust-garden that dust does contain living plants which, when they find food in a moist, warm place, will grow and multiply.

They were not seen when they settled out of the dust on the jelly, and not until they had reproduced

Colony of Dust Plants
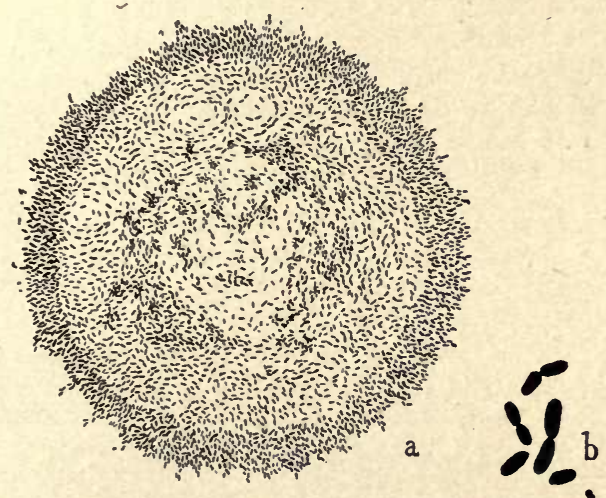

Fig. 6. (a) One Colony of Bacilli or Rod-Shaped Bacterla as Seen in

"Dust Garden." Highly Magnlfied.

(b) Elght Bacteria from the Colony, Magnified Much More. (After Prudden.)

themselves many times, so that a "colony" was formed, were we able to see that anything had been planted in the dust garden. But each colony or spot shows where a single plant dropped on the gelatine; the spot becomes visible only after it contains thousands of individuals, which are kept close together by the gelatine. 
Names of Dust Plants

All of these dust-plants have to be studied under the microscope and are therefore called micro-organisms. Microbe-a name given by Louis Pasteurwhich from its derivation would include all, has come gradually to be applied to one class, the bacteria. Still a third word, germ, which really means the beginning, or that first living cell which produces a more complex form, is becoming restricted to the micro-organisms that cause disease, as the germ of tuberculosis, the germ of typhoid fever, etc. All

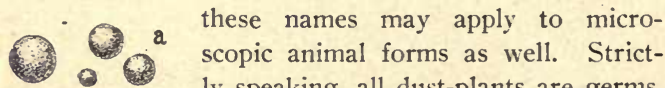
ly speaking, all dust-plants are germs, all are microbes, all are micro-organ. isms.

The "garden" will show twc kinds of plants and sometimes a third, although this is not so common in house dust. We will now see what these three kinds of plants are, two of which we may expect

F1g. 7. Ty p 1 c a 1 Forms of Bacterla. (a) Coecl, or Ball Forma. (b) Bacllil, or $R \circ d-g h$ a $p$ e d Forma. (c) Splrllia, or S p 1 r a 1 Forma. to find in all houses at any time. The third, wild yeast, would very likely be caught if we planted our dust garden under the apple trees in summer tine.

\section{BACTERIA}

Let us find out first what the plants are like which make the smooth, glossy, shiny colonies, whether round or radiate. These are the bacteria, and each colony 
has come from the reproduction of one parent-a bacterium. Fig. 6 .

Under the microscope these bacteria show three principal shapes. Fig. 7. One like a short, round stick or rod, is called a bacillus and bacilli for the plural. Fig. 7b. Another is ball-shaped, called coccus or cocci for the plural (the third $c$ sounding like $s$ ). Fig. 7a. A third form which resembles one turn or more of a screw is called a spirillum or spirilla for the plural. Fig. $7 \mathrm{c}$.

These typical forms may shade into each other. The bacilli may be long or short, with pointed, blunt, or square cut ends. They may be so short and plump as to closely resemble a coccus. Fig. 8. The spiral forms may curve very little or have decided and numerous twists. Fig. 9.

Bacteriologists do not always agree

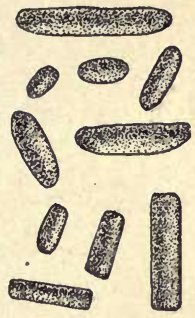

Fig. 8. Bactlll or Rod-shaped Bacteria. as to which class a newly found individual should belong, and to the housewife it makes no difference.

The bacteria are so simple in structure and so difficult to study that there is little to describe. Each Structure os Bacteria consists of a single cell, so far as is known. This seems to have a denser portion on the outside, which forms a cell wall and may be cellulose as in the higher plants.

This simple cell of protoplasm or "foundation stuff" 
is endowed with all the characteristics of living matter anywhere.

All living things whether plant or animal take food in some way. All, too, having taken food, change it over into their own substance and give out

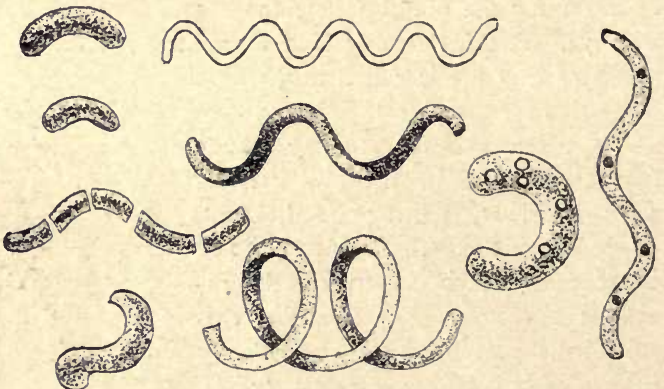

FIG. 9. DIFFERENT FORMS OF SPIRILLA.

some of the results of these changes as waste products in the form of gases, liquids, or solids.

Bacteria are no exception to this universal rule. Their products are either gases or liquids and these, dissolved in blood or other liquids, bring about various changes, the results of which may be either desirable or undesirable, according to the nature of the bacterium, the amount of the excretion, or other conditions under which the changes are wrought.

The processes of bacterial growth in the human body and in food substances are similar. 


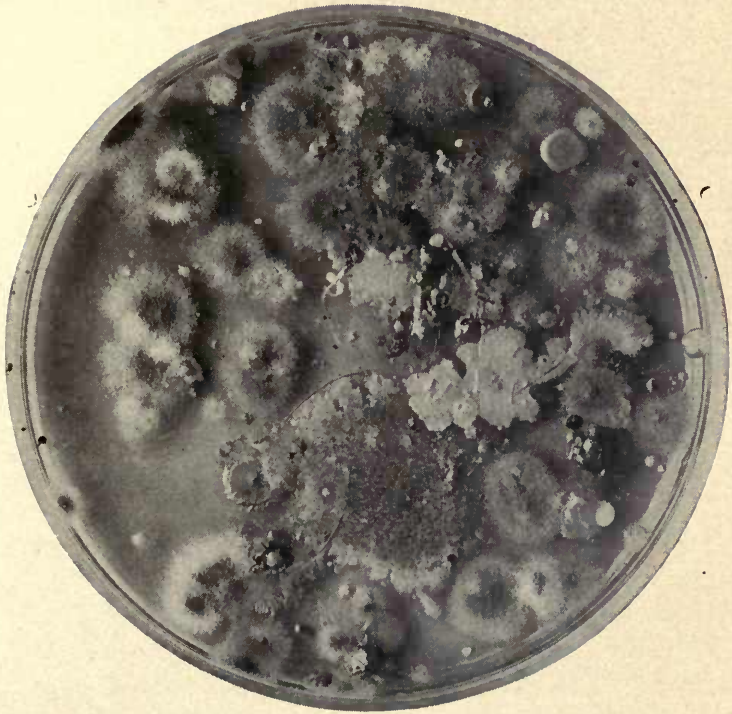

"DUST GARDEN" SHOWING ABUNDANT GROWTH OF MOLDS

Made by a Member of the A. \$. H. E. 

The excretions of the bacteria in milk, fish, etc, may produce changes which, very apparently, render them unfit for food, or the changes may not be apparent. If food containing these excretions be eaten, or if the bacteria grow in the body itself, the excretions may bring about abnormal conditions more or less severe, but all may be called disease.

Like the maggots in cheese or the clothes moth larva, the bacteria live surrounded by their food supply and they have only to take, digest, and absorb it as need-

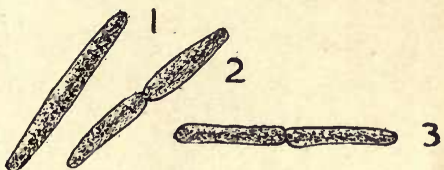

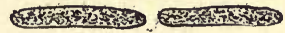
4

F1G. 10. A BaCILLUS DIVIDING INTO TWO GENERATIONS.

ed. Like these animal forms, they feed upon complex organized food which has been previously prepared by other plants or animals. In this they differ from most plants which must manufacture their food out of the mineral and other inorganic substances in air, water, or soil. However, some species can do this although they have not the green coloring matter or chlorophyll cells which in the higher plants are the food factories.

Because of this power of living on inorganic substances, which no known animal possesses, the scientists have decided that these micro-organisms must be called plants rather than animals.

Bacteria have no leaves, roots, stems, or any or- 
gans like higher plants. They are simply transparent bits of jelly-like protoplasm.

Food of
Baoteria man likes, although they do not require the variety in diet which to civilized man seems necessary.

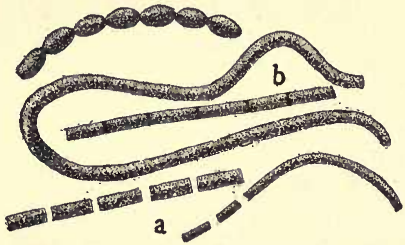

F1g. 11. Different Forms of Bacili.

(a) Simple, detacȟed forms.

(b) Chains of united bacili. Some flourish best in meat juices, others in milk, some in starchy foods, others in sugary solutions, while still others enjoy best the fats.

They also show, like man, a surprising faculty of adaptation. If unable to get their favorite food, many will grow on whatever is at hand. Any organic substance which is not absolutely dry may become food for some species of dust-plants. Dust-plants will not leave the moist surfaces upon which they fall, but where such surfaces become dry, then the plants are ready to be blown into the air by winds or carried along on anything which touches them.

Ordinarily dust particles are probably never so dry that the bacteria or other micro-organisms clinging to them are killed.

Reproduotion of Baoteris

All bacteria reproduce by division of the parent into halves, which process is called fission. Fig. Io. Sometimes these daughter cells remain attached even after they themselves have divided into two. A 
chain of cells results so that what looks under the microscope like one individual may be three or more generations. Fig. II.

The ball forms divide in the same way along a diameter. Some, however, divide in more than one di-

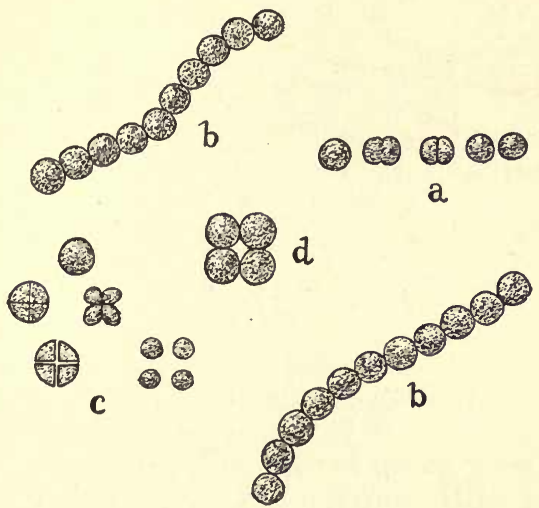

FIG. 12. REPRODUCTION OF COCCI BY FISSION.

(a) Division into two.

(b) Chains of cocel.

(c) Division into four.

(d) A sheet of four cocel.

rection, so that the colony of daughter cells may touch at one side only, like closely strung beads, or on two sides, making a sheet or film of cells, or they may become piled upon each other like a cube of marbles. Fig. I2. 
The spiral forms also may remain in one colony or break up into single cells after division.

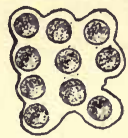

FIG. 13. ZOOGLOEA OR THE FILM-FORMING BACTERIA.

Sometimes they unite their bodies by a gelatinous film to form a slime over the surface of whatever they are growing upon, as seen on the walls of the waste pipe of the refrigerator or on the surface of the water in the pan. This is known as a zoogloea form. Fig. I3.

The rapidity with which they reproduce depends largely upon the food supply, the warmth and moisture-that is, whether the - conditions of life and growth are favorable.

In this prolific reproduction lies their great power for harm or benefit to the world.

In some species, under favorable conditions, a new generation is born oftener than every half hour. If this rate were continued for a day, one bacterium might become ancestor of over sixteen million descendants. Some interested observer has calculated that in two days the billions thus born would fill a pint measure and weigh a pound, while in another twenty-four hours their weight would equal eight thousand tons.

These numbers, however, are of no practical im- 
portance, for long before such a population was reached the food supply would be gone or the parent forms would be killed by their own excretions. Here, as in the animal world, if the wastes of living accumulate, death results. Yet wherever conditions of moisture, warmth, and food remain favorable they will multiply with almost infinite rapidity.

Botanically the bacteria belong to the fungi, and because they reproduce by fission or breaking into two, they are called Schizomycetes or Fission Fungi.

A string of sausages, often seen hanging in the windows of a market, is a fair representation, except in size, of a chain colony of bacteria.

Take a piece of white rubber tubing, ten to twelve inches long and from one-half to one inch in diameter. Tie it tightly at one end with waxed thread. Fill this about three-quarters full of water and tie the second end so that no water may escape. From thread to thread will represent very well a bacillus.

Divide this in the middle by a rubber band and two generations are represented or a chain colony of two individuals. The same method may be continued to show the future reproduction processes.

Their minute size would seem to indicate insignificance, but they make up in energy, in the work done, and in numbers, for all that is lacking in size. Not one is ever visible to the naked eye, while some can be seen only with great difficulty by the skilled observer and under the most powerful microscope.

They are so small that little idea of their size can

Bacteria

Are Classed as Fungi 
be obtained by actual measurement, only by comparison. Fig. I4 represents the largest bacterium known magnified six hundred diameters. One twenty-five thousandth of an inch is not an uncommon length for a bacterium.

Yet, small as they are, they are heavier than air,

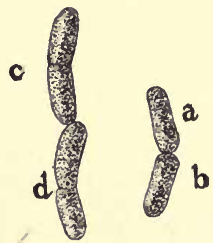

Fig. 14. Bacllius Megatherium.

(a and b) Individuals.

(c and d) Two Individuals, each dividing into halves. and therefore settle out of it when it is still.

It is estimated that in the space occupied by a grain of sugar there might be packed six hundred millions and each bacterium be comfortable. Compared with the bacteria which may lodge there, the wrinkles in the skin of our hands are like ditches six or eight feet deep. No wonder that it is difficult to dislodge them by any ordinary washing. The surgeon has to resort to a strong soap, vigorous brushing, and the use of numerous bacterial poisons in addition to the ordinary washing, before he is sure that these valleys aze not rich in the tiny plants that might bring suffering or death to his patient.

Most of the bacteria require oxygen to breathe, as we do, but some can live without air. Some will accommodate themselves to any condition. Preferring much or little oxygen, they will, however, grow under the opposite condition, if they must. 
Of course, the disease germs which grow in the interior of our bodies flourish best under conditions of darkness and lessened air supply. Out-of-door life, then, is a preventive measure. and next to this is a

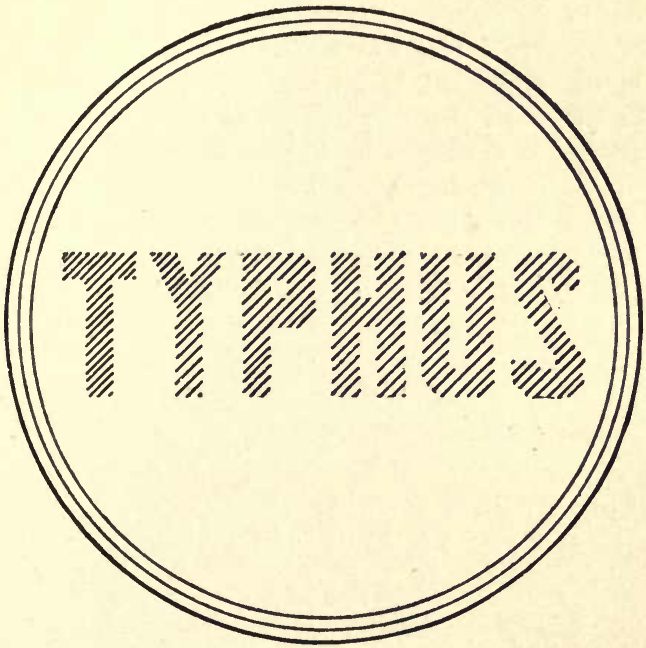

FIG. 15. SUNSHINE AS A DISINFECTANT. (After Lefar.)

Under the lettera of black paper there was growth; in the remalnder of the plate the sunlight killed the bacteria.

generous supply of sunlight and fresh air inside our houses.

Experiments have shown that the disease germs 
live much longer when grown in a cellar than when cultivated in the light rooms of a house.

Effect of

Sunlight

All disease germs, so far as known, are killed by direct sunlight. This was proved some years ago by planting a Petri dish with typhoid fever germs. Half of the dish was covered with black paper, while the uncovered half was exposed to direct sunlight. On the sunlighted half no growth appeared, while the other half showed many colonies. A similar experiment is illustrated by Fig. I 5 .

In this experiment the letters of the name "Typhus" were cut out of black paper and placed on the under side of the cover of a Petri dish which had been planted with bacteria. The dish was exposed to sunlight for an hour and a half and then left in a dark room for twenty-four hours. When the paper letters were removed, the space covered by them was found thickly studded with the minute colonies of bacteria. The rest of the plate showed no appearance of bacterial life.

Power of

Some bacteria, like most of the higher plants, remain stationary, hàving no power of motion, while others move by slow or jerky, worm-like contractions. Still others are moved about by whip-like extensions of their bodies, called flagella or cilia. Some have only one whip at one end of the body, others one or a cluster at each end, while others have them reaching out from all parts. Fig. I6.

Some bacteriologists place all the forms which have 
flagella in one species-Bacillus, and all without flagella in another species-Bacterium.

When for any reason there comes a period of hard Spores times in the life history of the bacteria, such as cold. dryness, or lack of food, some bacteria have the

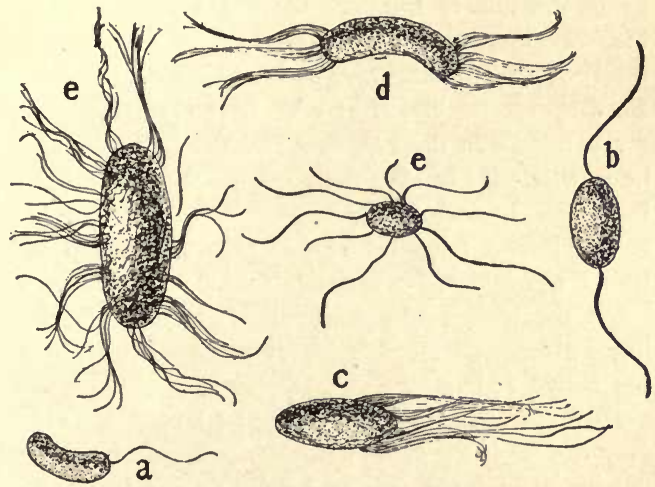

FIG. 16. BACTERIA WITH FLAGELLA.

(a) A flagellum at one end.

(b) A flagellum at each end.

(c, d. and e) Tnfta of flagella in different positions.

(After Conn.)

power of contracting their bodies into smaller space. possibly drawing it all into one end or from the middle into each end. Fig. I7. This is called the spore stage. These spores can weather great extremes of famine or cold or resist the action of strong chemicals. Some can be frozen, others boiled and still retain life. When good times return in the form of 
moisture, warmth, or more food, the resting, resistant spore starts into growth again and continues its life as before.

Resistance of spores

Dust Plants in the Refrigerator

The species that do not form spores are much more easily killed. Those that form spores readily, being difficult to kill, are more likely to cause disease or destruction of property. Fortunately for us, most of the disease or "pathogenic" germs do not. form spores readily, if at all. It is these spores that make necessary the repeated "scalding" by which the housewife tries to save the food which she finds spoiling.

The lowest temperature known will not kill some bacteria, while some varieties in the spore state will resist the temperature of boiling water. Indeed the heating sometimes seems to favor their changing into the active state.

Dust readily finds access to the ice box or the refrigerator, even if the ice is thoroughly cleaned before it is put in. The dust-plants will grow on any bits of food carelessly dropped and by their gaseous products may taint the meat, milk, and other foods. The escape pipe of a refrigerator needs to be often and carefully cleaned throughout its entire length, else it will be covered with a slimy mass of bacterial growth. Many of the bacteria found here are the germs of putrefaction.

This pipe may be cleaned with a swab of cloth or sponge tightly wrapped around a long stick, rattan or whalebone, with a small, long-handled brush, 
or if the pipe is too difficult of access for these methods, a boiling hot solution of washing soda may be poured down once a week, or when the ice box is empty.

The pan under the refrigerator should be scrubbed carefully with hot soapsuds or scalded with the wash-
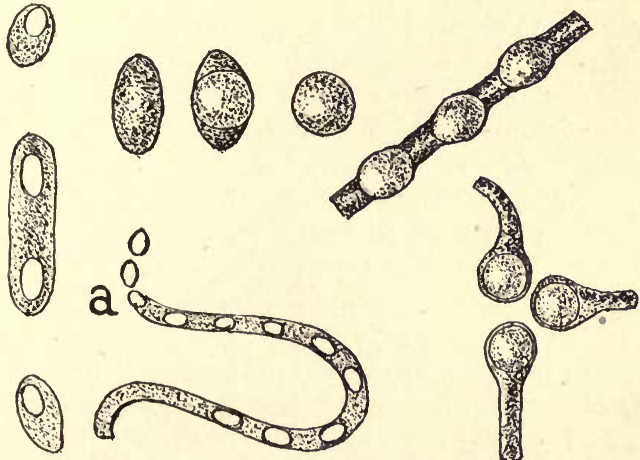

FIG. 17. VARIOUS SPORE BEARING BACTERIA.

(a) Spores Escaping from Ruptured End. (After Conn.)

ing soda, that no slime may appear. The escape pipe, too, should be opened to the air and in a place where the air will be pure.

The housewife who allows her refrigerator pipe to empty directly into a hole in the cellar floor, underneath which is a slimy mass of muddy filth, need not be surprised that milk and butter do not "keep well." 
Boiling Clothes

Natural Home of Bacteria

The greatest argument in favor of boiling clothes in the laundry is based on the bacteriological reason. Body clothes, bedding, towels and handkerchiefs may all become soiled with discharges of the mucous membranes of the body or from some wound or pus formation. In most of these discharges there is sure to be bacteria. Soap has a slight disinfecting power, but the boiling is far more efficacious. Scalding or the pouring of boiling water over the clothes is not sufficient for disinfection, for only the top surface is subjected to the high degree of heat necessary to kill the germs. Soap or other alkali, boiling, fresh air, and sunshine are a sanitary quartet whose work results in sterilization-that is, in death to the germs.

The natural home of the bacteria is the soil. Here they are most numerous because here they have their greatest field of work laid out for them, which is to change any dead vegetable and animal matter that may be present into inorganic substances which can do no harm to life.

When winds blow over the soil they raise the dry dust particles laden with bacteria into the air; rain washes millions of them from the air and soil into the brooks and rivers; therefore, all surface waters are seeded with bacteria.

From the soil they may be directly brought into the house on shoes, or clothes, or hands; indirectly through dusty air.

The cleaning of shoes on a mat, brush, or scraper 
outside the front door is a habit to which all children should be trained. Adults should think what it means to bring street filth into the dry, warm house. If all coats, dresses, etc., worn on the street could be brushed out of doors still another fruitful source of dangerous dust would be avoided. House air is found to contain thousands of bacteria, where out-ofdoor air may have only hundreds, because moist surfaces catch and hold them. Sunlight and large amounts of fresh air tend to kill them. The house has less fresh air, less sunshine, and it is filled more or less with dry, rough furnishings, which add to the dust and all tend to hinder its removal and to lessen the chances of disinfection.

In the laboratory bacteria are studied in many ways. Under the microscope is noted their shape and size; what kind, and the rapidity of motion, if any; how they tend to arrange themselves upon division; whether spores are formed or, not.

From plate and other cultures can be seen the shape and color of the colony; whether they grow best on the surface, in much air, or below the surface where air is excluded; whether the temperature of the room is more favorable than that of the incubator, which is much higher and represents more nearly the conditions inside of our bodies.

Some of the bacteria secrete an acid which liqueBecretions fies the gelatine on which they may be growing. This acidity can be detected by litmus paper. Some produce a gas when grown in a sugary solution, others

Laboratory Study 
cause putrefaction. Each of these differences means much to the trained observer, for from such results has been and must be gathered our knowledge of their probable behavior outside of the laboratory.

Importance
of

In the bacteriological laboratory has been found Bacteriology out facts which in the commercial life of the world mean millions of dollars; there. too, have been started experiments which have led to incalculable saving of human suffering and life, through sanitation, preventive medicine, and surgery.

Here we see how the little things of life have confounded the mighty and how "the science of the infinitely small," by which some one has defined bacteriology, "has become the infinitely important." 
MOLDS

Another micro-organism which is seldom absent from house dust, either as the plant cell itself or its spore, is mold. This in our dust garden formed the :olonies with dark centers and a velvety pile. Molds

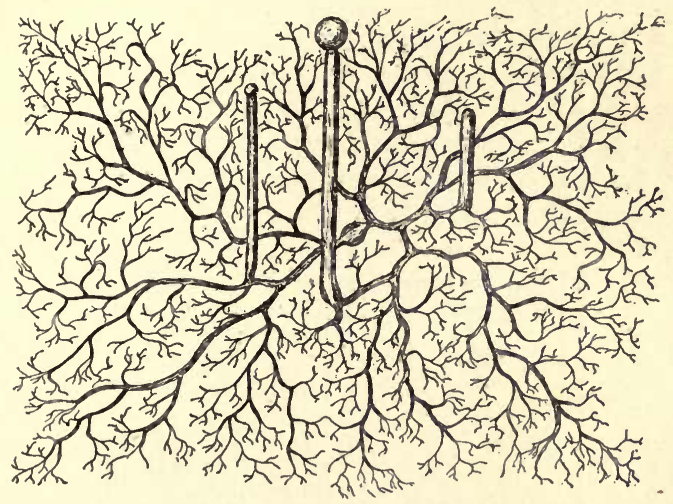

FIG. 18. A GROWTH OF MOLD.

Mycelium, Hyphae and Spore-cases. (After Jorgensen.)

consist of vegetative portions which grow out in long threads, and these by budding and branching unite to form a network over the substance they are using as food. Fig. 18.

From this network or mycelium grow out cells called Reproduction hylhac set apart for special work-that of bearing the reproductive portion-the heads or stalked clubs. Inside these heads or from their outer surface

Growth of Mold 


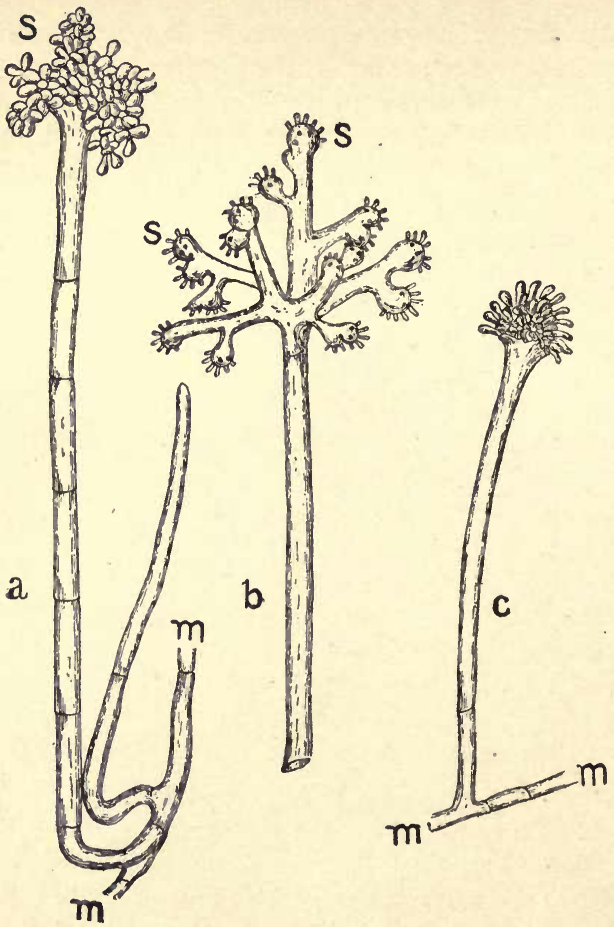

FIG. 19. MOLDS SHOWING A MYCELIUM BRANCH, (m.)

(a) With ripe spores (s).

(b) A spore-bearing staik with spores just forming.

(e) Spores bave fallen. (After Jorgensen.) 
grow the spores which are to reproduce the species. Figs. I9 and 20. Each head produces thousands of dust-like spores. Fig. 2I. This is the common method of reproduction in the molds, although some, like the bacteria below them in the scale of nature, break the parent cell into segments, while others send off buds like yeast. These buds form directly the second generation.

When the invisible spore falls upon a moist, warm surfące, it immediately begins to grow by sending out the mycelium branches, which will then proceed as before to develop more spore-bearing cells.

Sometimes these mycelium cells penetrate into the food substance, very much like the roots of the higher plants.

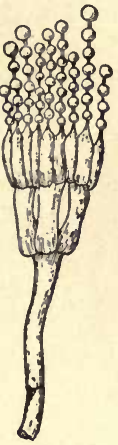

FIG. 20.

One of the effects of mold growth is seen in the softening of cellulose in fruits, vegetables, etc. This makes their decomposition by the bacteria more speedy and thorough. Out-of-doors this action is of great use in the economy of Nature, but inside our houses the presence and growth of molds should be guarded against in every way.

In general, molds will grow with less moisture than bacteria, and.some of them flourish in the light. They increase rapidly after rainstorms and are much less affected than the bacteria by winds. They need organized food, as we well know from the places where we find them growing-bread, meat, leather, sugary liquids, or even in vinegar. 
Work of Molds

In general, they form fewer desirable products than do the bacteria, although this may be considered a matter of taste. Those who like Limburger and Brie cheese; the Chinese "soy," which is made from a kind of bean on which mold has grown; the Japanese "sake" or rice wine, which has been fermented by molds-these persons certainly would claim that molds were as valuable in the production

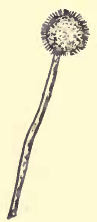

a

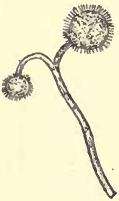

b

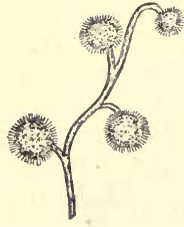

C

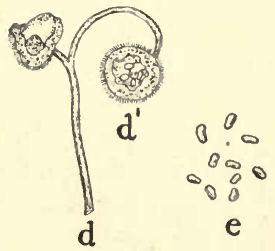

d

FIG. 21. DIFFERENT STAGES IN THE DEVELOPMENT OF MOLD. (a, b, c and d) Growth of the spore-cases.

(d') The spore-cases open.

(e) Spores. (After Jorgensen.)

of flavor as the bacteria are in butter and ordinary cheese.

Just what their action is upon digestion is not definitely understood. It is thought that many of them cause a lax condition in the bowels, possibly diarrhœa.

Disease

They are found to cause various diseased condifrom Molds tions of the skin-Ringworm, Thrush, and Moth. The moth patches, often called Lizer spots, because believed to be due to an inactive liver, are found to be caused by mold spores which have gained access to 
the body tissues through some break in the skin. Fairly strong acetic acid-40 per cent-is one of the best remedies for moth.

They sometimes penetrate quite deeply into the tissues, causing irritation, inflammation, of sores very difficult to heal because there can be no healing until the plant is killed.

Food fully penetrated by mold growth would better be destroyed. When the growth occurs only on the surface, as on jelly, olives, pickles, etc., the mat of cells protects the food beneath and most of it is unharmed. Such foods, however, are often softened by the products of mold and bacterial growth, when no sign of mold appears on the fruit itself. If eaten, various intestinal disorders are liable to occur.

Moist cloth furnishes favorable soil for mold when Mildew warm and not open to fresh air. The folded garments laid away gather moisture; dust containing mold spores is usually present on them, and in time, soon or late, the garments grow musty even if there be no visible mold. Mustiness is the proof of mold, and mold the proof of dampness and dust. We call the mold growing on the cloth mildew, but called by either name it is the same dust-plant. The plant must be killed to stop its growth. If it has grown only on the surface of the fibre, the stain may sometimes be removed without serious injury. If it is of long growth or has penetrated the fibre, a hole will result, because of the weakened or actually destroyed fibre. So far as the healthful house is concerned, there 
need be no separation in the mind between molds and bacteria, because the occurrence and conditions of growth of both are practically alike. So far as is known, there are no molds that cause such serious and fatal diseases as some of those caused by bacteria.

Because molds are lighter than the bacteria, it takes much longer for them to settle. The air, then, is likely to contain molds even where it has been quiet so long that the bacteria have all settled. This gives the housewife another reason for the economy of keeping the air of her kitchen, pantries, or any place where food is prepared or stored, as free from dust and as dry as possible.

In old houses it is sometimes impossible to keep food in certain closets or cupboards. The woodwork or plaster and therefore the air is so charged with mold spores that one damp day or the presence of warm, moist food alone will cause them to spring into growth. Such places should be often whitewashed and painted or disinfected.

The spores of molds are often very beautiful in color when seen in mass, and under the microscope they show exquisite forms and delicate ornament. These factors, as well as the substances upon which the mold grows, are used as means of distinguishing species.

The botany of molds is to many as interesting a study as that of the higher plants. Only a microscope can bring out the beauties of this class of dustplants, which from the standpoint of economy and health the housewife can view with disfavor second 
only to that she bears for some of the bacteria. So many more of the bacteria are friends rather than foes that it may be more just to place mold as her chief enemy.

\section{YEAST}

The third variety of plants found in dust is yeast. These are not usually so numerous as either the bacteria or the molds, although about apple trees in the country wild yeasts are common. Like a bacterium, the yeast plant is a single microscopic cell of protoplasm enclosed by the cell wall. It is round or oval in shape and often one two-thousandth of an inch in diameter. Fig. 22. It is therefore quite a giant compared with the smallest bacterium.

If a drop of tepid water in which bread yeast has been dissolved be carefully watched under the microscope, the changes shown in Figs. 23 and 24 may be seen. One cell will be seen to swell a little at one part. This bud or daughter cell will bulge out more and more from the parent and may even produce one or more generations from itself before it breaks away. This "budding" is the method of reproduction common to yeast plants of which there are many varieties.

Some species, however, reproduce by spores very Spores much like the molds. Such yeast cells will be seen to divide within the cell wall into two or four rounded bodies which in growing soon rupture the parent cell and escape. Fig. 25. Each of these liberated spores forms a new plant which may produce buds.

Size and of Yesst 
Requirements for Growth

Thus the generations are continued and the individuals multiplied.

Yeast requires food, oxygen, warmth, and moisture. Sugary substances are especially liked by the yeast which is used to make bread. This is a specially cultivated form of brewer's yeast. Yeast directly from
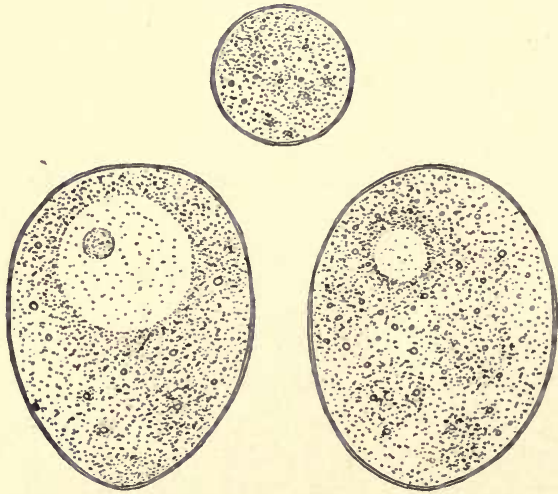

FIG. 22. TYPICAL FORMS AND APPEARANCE OF BREWERS' YEAST. (After Sedgwick and Wlison.)

the breweries is often used for breadmaking. It is while feeding upon these sugary solutions that the tiny plants bring about the chemical changes by which alcohol and the gas, carbon dioxide, are produced. The gas puffs up the dough and makes pos- 
sible the raised bread, or the "election cake" like that of our grandmother's time; it also produces the "froth" and "sparkle" of the "home-made spruce beer" as well as that of the large breweries.

Yeast plants grow best from $70^{\circ} \mathrm{F}$. to $90^{\circ} \mathrm{F}$. They

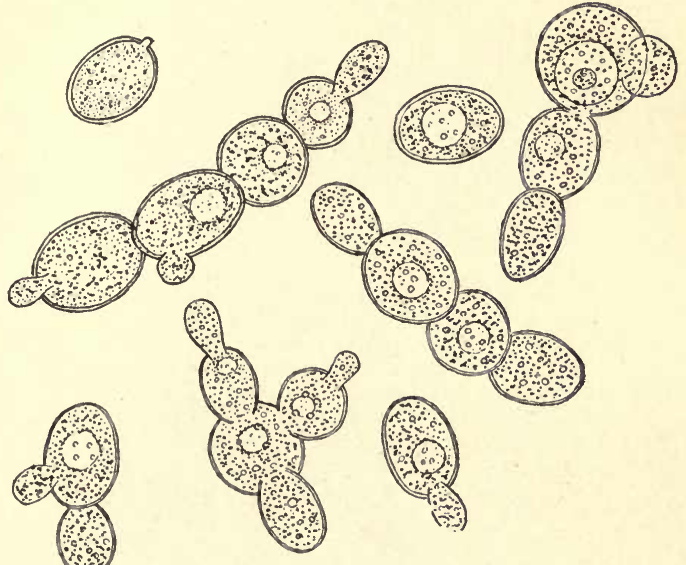

FIG. 23. A YEAST GARDEN.

do not work well under $70^{\circ} \mathrm{F}$. and are killed when in a moist state by the temperature of $130^{\circ}-150^{\circ} \mathrm{F}$. No wonder the bread will not rise when the cook pours boiling or even hot water on the cake of yeast! Dead plants cannot work any more than dead animals. No 
working by the yeast means no possible raising of the dough by the gas. Sometimes the dried yeast cake has been carelessly prepared in this respect and the yeast plants are nearly all dead.

Cold and Yeasts

The yeast plants can endure cold better than heat.
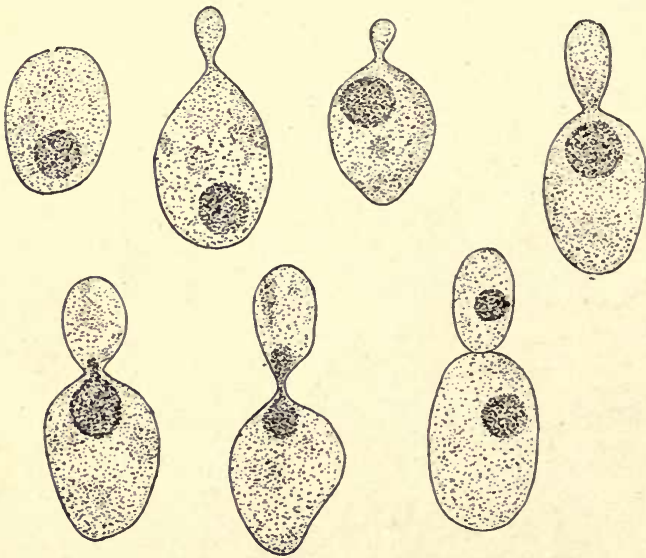

FIG. 24. YEAST PLANTS IN VARIOCS STAGES OF BUDDING OR REPRODUCTION. (After Sedgwlek and Wilson.)

It hinders their work but does not quickly kill them. To show the favorable or unfavorable temperature for the growth of yeast plants, take one-half cup each of boiling, lukewarm and ice-cold water. Add to each one tablespoonful of molasses and one- 
sixteenth of a cake of compressed yeast. Put each portion into a clear glass bottle or tumbler and place all three in a warm place, about $75^{\circ}$ or $80^{\circ} \mathrm{F}$., for an hour or two. Watch carefully for the first sign of bubbles which show that gas is forming. Note in which glass the larger amount of gas is found.
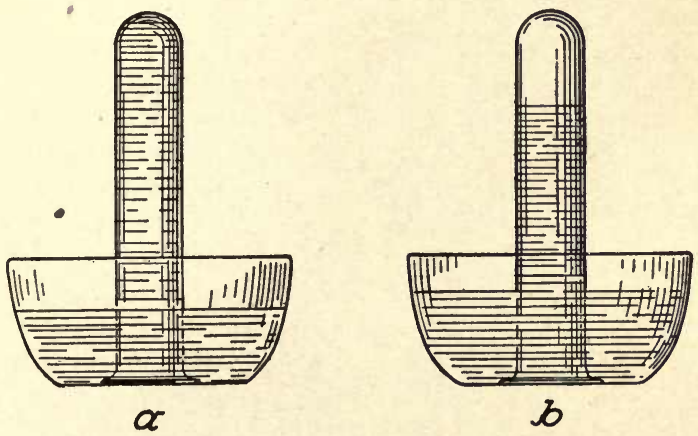

FIG. 26. YEAST GENERATING CARBON DIOXIDE.

(a) Tube flled with molasses and water.

(b) Carbon dioxide collecting in top of tube.

Fill a test tube or thin, clear glass vial with a mixture of molasses and tepid water. Add a little yeast and invert the vial in a dish which also contains molasses and water. Fasten the vial so that it will remain standing, closed, in the dish for a day or more. Fig. 26, $a$ and $b$. 
The Gas Produced

Compressed Yeast

The gas will be formed, replacing the water in the vial. If a burning match is held in the mouth of the tube as it is removed from the water, the flame will be extinguished. This indicates that the vial contains the gas carbon dioxide; or a teaspoonful of clear lime water may be poured into the vial and shaken about in it. The carbon dioxide present will turn the lime water milky from the insoluble carbonate of lime (calcium) formed.

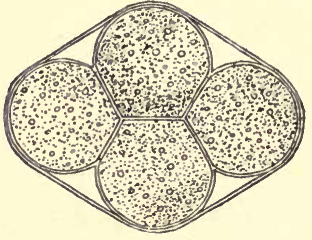

FIG. 25. A YEAST CELL CONTAINING FOUR SPORES.

Compressed yeast is simply a mass of yeast plants mixed with some form of starch and pressed into cakes. A two-cent cake is said to contain over half a billion yeast plants.

As these cakes are made .or a special purpose they should contain only one species of yeast. They do, however, contain bacteria and if the dough is allowed to rise too long or at too high a temperature they grow and produce an acid which makes the bread sour; so that sour bread results from the growth of bacteria and not from the yeast. When pure yeast is used and all conditions of cleanliness are carefully looked after no sour bread results. A dusty kitchen or unclean utensils may increase the danger from bacterial growth. If the bread be made with milk, this should be scalded to kill the bacteria always present. As we have seen, milk is rich in dust-plants, especially 
bacteria, and the dirtier the barn, the cows, the pails, or the clothes and hands of the milker, the more bacteria the milk contains.

The baking of bread should kill both the bacteria and yeasts, as well as molds, if any are there. But it will not do this unless continued for a long time, because the inside of the loaf will not be raised to a temperature sufficiently high. The moisture in the interior prevents a temperature much higher than $212^{\circ}$ and it may remain far below this.

In the laboratory bread has been made from the yeast plants found alive in the center of a slack-baked loaf. The bread should remain in the oven until well done, then when removed

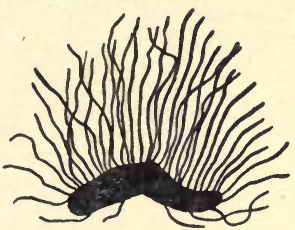

Fig. 27. Bacteria Found in the "Eyes" of Potatoes. it should be cooled as rapidly as possible, that all growth of yeast or bacteria may be stopped.

The custom of some housewives of wrapping the hot loaf in thick cloth that the steam may soften the crust is entirely wrong from a bacteriological standpoint.

During the baking the alcohol and carbon dioxide are both driven off.

Coarse breads, those containing mùch bran especially, need thorough baking, because on the outside of Coarse Meals the grains are often certain bacteria, the spores of which are very resistant to even high heat.

Baking Bread 
Some of these are found in large numbers in the soil which clings to underground vegetables, especially in the "eyes" of potatoes. No wonder a vegetable brush is necessary to clean away these clinging arms! Fig. 27. 


\section{TEST QUESTIONS}

The following questions constitute the "written recitation" which the regular members of the A. S. H. E. answer in writing and send in for the correction and comment of the instructor. They are intended to emphasize and fix in the memory the most important points in the lesson. 



\title{
HOUSEHOLD BACTERIOLOGY
}

\author{
PART I.
}

Read Carefully. Place your name and address on the first sheet of the test. Use a light grade of paper, write on ont side of the sheet only, and leave space between answers. Use your own words, so that your instructor may know that you understand the subject. Read the lesson book a number of times before attempting to answer the questions. Answer every question fully.

I. What are bacteria? Describe them.

2. What other microscopic forms are found in dust and what are favorable conditions for the growth of these dust-plants?

3. Where are bacteria most numerous and what is their chief work in the world?

4. In what ways are bacteria helpful to man and in what way do they injure him or his possessions?

5. Why should food eaten raw or unskinned be thoroughly cleaned?

6. What sanitary end is attained by cooking food?

7. Why are oranges and bananas safer fruits than grapes or peaches bought from a street vender?

8. How can scalding apple or other sauce prevent its spoiling, and why scald it more than once? 
9. What common diseases in man are attributed to molds?

Io. What is mildew, and under what conditions in the house would it be likely to appear?

II. Are molds ever helpful to man?

I2. From the health standpoint, what clothes are most likely to need boiling?

13. Why should milk receptacles be thoroughly scalded or sunned?

I4. When a can of blueberries ferments or "spoils," what does it mean?

15. Why are bacteria considered to be plants?

16. How do bacteria reproduce themselves and what food do they prefer?

17. What is the typical mode of reproduction in yeast? In mold?

18. What is the chief work of the yeast plant?

19. Give a report of your dust-garden experiment.

20. What do you consider the most important ways in which you have applied the knowledge gained from this lesson?

21. Are there parts of this lesson that are not clear? Have you some questions?

Note_-After completing the test sign your full name. 


\section{HOUSEHOLD BACTERIOLOGY}

PART II 


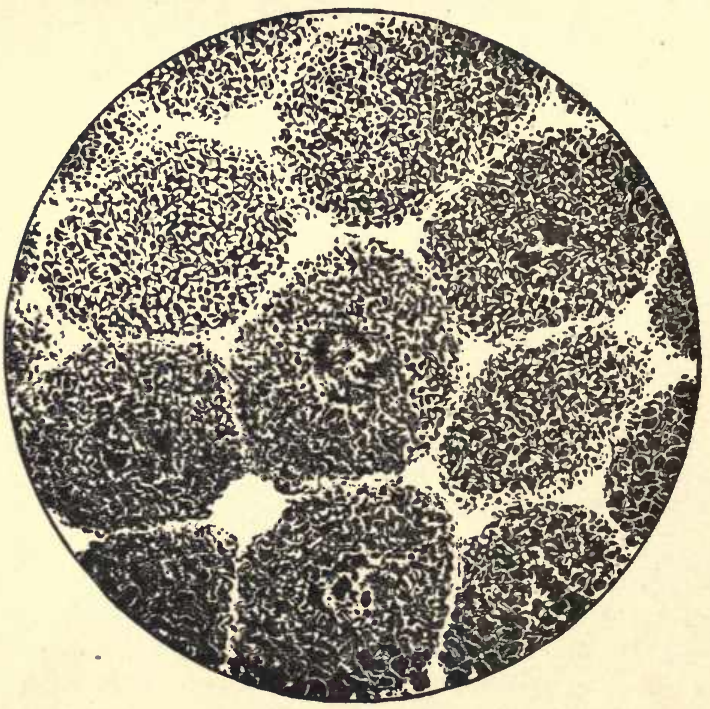

CELLS OF CLOVER TUBERCULE, SHOWING BACTERIA HIGHLY MAGNIFIED 


\section{HOUSEHOLD BACTERIOLOGY}

PART II.

\section{WORK OF BACTERIA}

When bacterial life first appeared upon the earth may never be known, but that it existed thousands of years before man made its acquaintance is surely true. Indeed, it was within the last quarter of the nineteenth century that the knowledge of bacteria became of value or was reduced to a science. The problems of bacteriology are now being solved very rapidly. What future generations may add, who can tell?

Although bacteriology is the youngest of all the sciences, it occupies a very important place among them because of its intimate connection with disease, with sanitation or the prevention of disease; with successful agriculture, and with the manufacture of many products.

In the eyes of the law every person is considered innocent until proved guilty. It may be well for us to look at the beneficent role which bacteria play in the world, that we may the more justly consider their harmful work. We can hardly believe that the most numerous forms of life were intended to work only harm to man. 
As soon as an organism begins to live it begins to die; that is, certain cells or parts of cells die and are perhaps cast off from the rest that the whole may

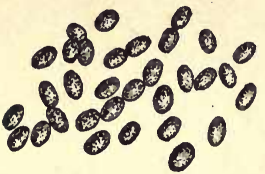

Fig. 28. Bacteria in Soll which Help in Making Plant Food. not be injured. Animals and plants die and become dangerous to the welfare of other animal life, especially to man. The wastes of life, of his own life even, are man's greatest menace.

Bacteria a: Scavenger:

Here come to his aid these microscopic scavengers, the bacteria. No doubt the molds assist in the process but the balance of the work is done by the bacteria present in such infinite numbers everywhere on the earth where organic matter exists.

Through their agency all dead animal and vegetable substances-that is, all organic matter-are changed into inorganic matter, into the chemical compounds or elements out of which they were originally constructed, and which are harmless or helpful to the life of the world.

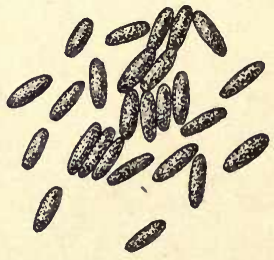

Fig. 29. Bacteria Found in Soll and on the Roots of Clover, Peas and other Leguminous Plants.

A tree falls in the woods; an elephant or a bird dies in the jungle; just then and there the millions of bacteria in the soil and the air are ready to seize upon the dead bodies, and in time all the animal and vege- 
tables tissues are changed into gases which dissipate into the air or reunite into compounds that form a part of the soil. These then become once more food for plant life, and this, in turn, for the sustenance of animals.

Bacteria are the agents of decay by which all organic materials are returned to the soil or the air. Thereby life is not only made possible, but also is sustained. What the conditions would be were these invisible agents to cease their beneficent work of scavenging can be scarcely imagined. Life as we know it on this earth could not exist were these dust-plants not present.

All animal life is de-

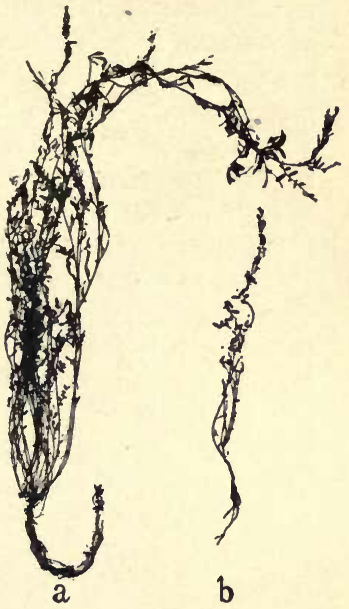

FIG. 30. A VARIETY OF PEA. (a) Grown in soll with the proper nitrifying bacterla.

(b) Grown under the same conditions without the bacteria. pendent directly or indirectly upon the vegetable kingdom for sustenance. Man takes both animal and vegetable food, but he is not able to manufacture this food out of the inorganic elements.

Plants use for their food gases, water, and various salts usually dissolved in the water. In sunlight the 
green leaves through their chlorophyl cells are able to take most of their carbon from the carbon dioxide of the air. Some oxygen is also taken from the air, but most of it is absorbed by the rootlets from the ground air, the water in the soil, or from organic compounds in solution in the water. Hydrogen is obtained from water and other compounds containing hydrogen and is taken in through the rootlets.

Nitrogen Not Taken Direct

No plants can take their nitrogen directly from the air. Although this gas with oxygen comprises the major part of the atmosphere in which all vegetation is bathed, it is not taken in through the leaves as the carbon dioxide is.

A government bulletin says: "Ever. since anything has been known in regard to plant nutrition and the necessary part that various gases and minerals play in the successful growing of crops, scientific men have realized the great importance of conserving the world's store of nitrogen and have made every effort either to husband or to increase all available sources of supply. In the early days, when it was first realized that nitrogen was so essential to plant life-in fact, was at the very foundation of agriculture-no particular alarm was felt. Botanists had demonstrated that plants obtained their carbon from the carbon dioxide of the air, and since this gas is present in so much less quantity than nitrogen it was believed that by no possible means could the most essential of plant foods be exhausted. However, when it was shown that plants 

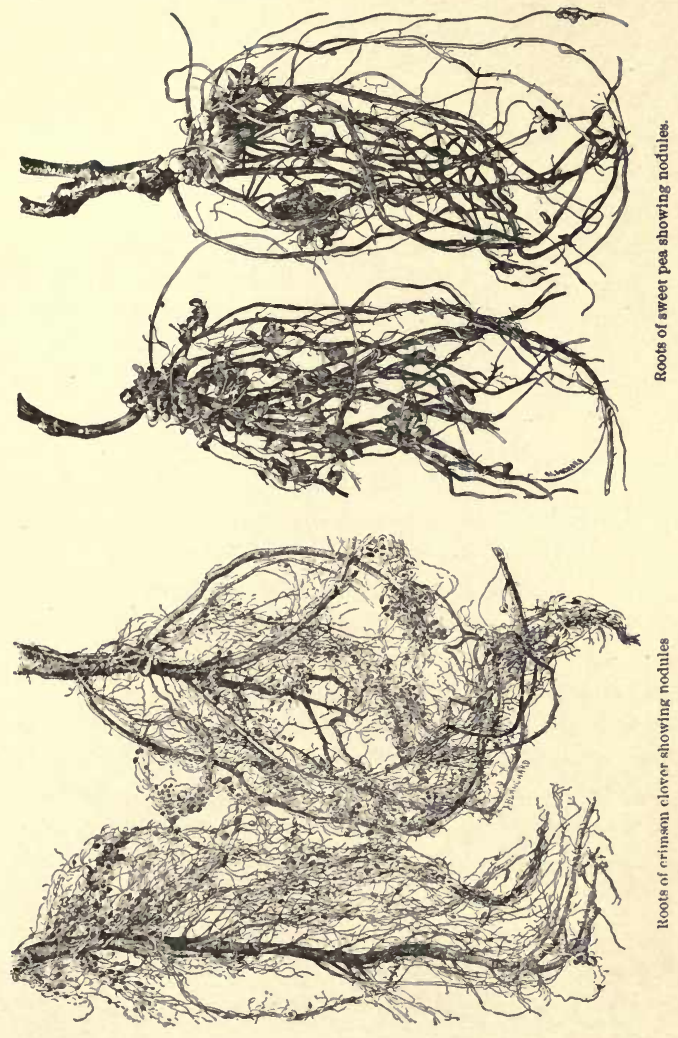

were unable to use free atmospheric nitrogen and must obtain it directly from the soil in a highly organized form, the importance of the problem increased greatly, and the gravest consequences were predicted by those familiar with the rapidity with which this valuable element was being wasted."-Farmers' Bulletin No.' 214, Beneficial Bacteria for Leguminous Crops.

Nitrogen in combination available for plant food is wasted in many ways. Food and other organic wastes, as sewage, are burned or run into the sea instead of being returned to the earth, which is the natural place of disposal.

There are natural sources of stored nitrogen in saltpeter beds and guano deposits, but these are rapidly disappearing. Even if they were sufficient in quantity they are not everywhere present and therefore must be expensive. Their aid would not be available for all.

The bacteria are more generally present and ready to work. Although unknown and therefore uncredited, they have been working during all the ages since vegetation appeared, not only by their general agency in producing fertility of the soil through the products of decomposition, but also in certain plants through their ability to take from the air its free nitrogen.

From the earliest days of agriculture it has been recognized that all plants belonging to the leguminosae have a decidedly beneficial effect upon the soil. Pliny wrote: "The bean ranks first among the legumes. 
It fertilizes the ground in which it has been sown as well as any manure." The lupine and vetch are also mentioned in ancient writings as enriching the soil and supplying the place of fertilizers.

Nitrogen

Traps

Enrich the Soil

Inoculating the Soil

On the roots of these leguminous plants, clovers, alfalfas, peas, beans, etc., are seen little nodules which have been found to be filled with bacteria. Fig. 29. If these "nitrogen traps" are absent or are removed the plants are less vigorous. Fig. 30 shows the comparative size of two plants of a variety of pea; (a) grown on soil containing the proper kind of bacteria; (b) grown in the same conditions and soil, but without the bacteria. The nitrogen is stored up in the knots, swellings, or nodules on the roots.

Not only do these nitrifying bacteria thus feed the plants which carry them, but also when the plants decay they enrich the soil in which the plants grow. Soils "run out," as the farmers say, that is, there is not plant food enough to sustain luxuriant vegetable life. Here is a place for the legumes to supply with their tiny balls of bacteria the nitrogen which has been withdrawn. In some way, not understood, the clover or similar plant in company with the bacteria stores up nitrogen from the air, which is finally returned to the soil when the decomposition bacteria have accomplished their work, thus making the soil richer in nitrogen.

When the proper kind of nitrifying bacteria are not present, the scientist comes to the aid of the farmer 
and supplies him with artificially grown bacteria with which he may inoculate the soil or seed. If the soil is favorable otherwise, the crop is greatly increased and in time the soil made more profitable for other crops.

The wise farmer does not plant potatoes or corn in the same piece of ground two years in succession, Rotation of Crops unless he adds large quantities of fertilizer or plant food. He rotates his crops because different species of plants take from the soil different kinds or amounts of food.

Even if these two fields of work-scavenging and aid in agriculture-were all in which we make use of bacteria, their claim of helpfulness would be overwhelmingly proved; but other results of decomposition processes are valuable in the arts and in the commerce of the world.

By the action of bacteria upon the whitish juice of certain plants fermentation processes are set up which Fermentation result in the blue indigo so important in dyeing industries. Our grandmothers would have been surprised indeed had they understood that their solid bluing was once a white liquid.

Bacteria, too, make possible the retting of the flax, whereby the fibres are separated from the stalk to be finally woven into the beautiful "pictures in white" we call table damask.

They bear their part in the preparation of sponges and in many processes of tanning and tobacco curing. 
In these "maceration industries" advantage is taken of Nature's methods of decomposition and what she did for countless ages before man studied her "ways and means" he still lets her do for his own and the world's commercial benefit. Her bacterial agents are

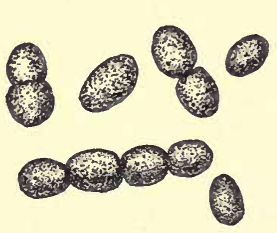

Fig. 31. A Bacterium Which Makes Milk Sour.

as ready to work on the large scale of his planning as on the small scale of the stems of mignonette left too long without fresh water in a vase on our tables.

Yet these are not all. Not only do they act directly and indirectly in furnishing food to plants, which afterward become food or fuel to animals and man, and prove a source of wealth to man in his industries, but they also greatly increase the variety and the palatability of his food.

Milk as we know it always contains bacteria and Production is an excellent culture material for their growth. Such a universal condition suggests some important results to be attained.

Most housewives know that while cream may be sour it is not so sharply acid as the milk from which it was taken. The addition of a little salt or sugar and spices may counteract this acidity and the result be a most delicious sauce. The large amount of fat in 
the cream is not a favorable food for the lactic acid bacteria. Fig. 3I.

\section{BUTTER MAKING}

Butter is usually made from sour or "ripened" cream and this ripening is the work of bacteria. The bacteria which cause the ripening are of different species, which grow best at different times and under different conditions. As the result of their growth are produced many different odors or flavors in the cream and the butter. Those that make the most desirable flavor, aroma or taste flourish best in May or June in this part of our country. Therefore, butter made from

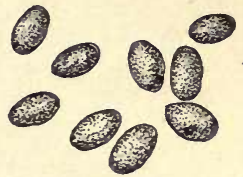

Fig. 32. A Bacterium Which Gives a Pleas. ant Odor to But. ter. (After Conn.) cream ripened by these bacteria has the qualities which have made "June butter" a synonym for the best. Figs. 32 and 33 .

Conditions over which the housewife has little control may interfere with the products. If the weather be warm and moist, the cream and butter need different care than when the temperature is low, the air dry or the climate equable. She therefore tries to produce an artificial climate by putting her cream and churn in a cold room and the butter in the refrigerator. 
This flavor production is a true process of fermentation or decomposition and like any other must be stopped at just the right time or results most undesirable will be obtained.

The skilled butter maker knows how careful she must be with dairy floor and shelves, milk pans, skimmer and churn as well as with the milk, the time of skimming, the temperature

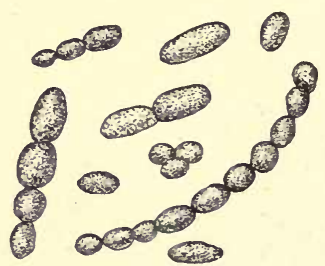

Fig. \$3. A Bacterium Which Makes Good Tasting Butter. and age of the cream, etc. From milk kept in some dairies it is impossible to make good butter - the wrong kind of bacteria are there. This is usually the result of uncleanness somewhere, it may be outside the dairy or it may be within.

This natural process of cream ripening may do for the small home dairy where all milk and its care can be under constant superrvision; but in the public creamery, which receives milk from many breeds of cows under varying conditions, such chance ripening would lead to failures and much financial loss.

When a pink or a rose is found to have a peculiar fragrance, color, or shape, or to keep longer than others, and this is perpetuated by cultivation, why not a certain "June flavor" bacterium? This is just what is done. Fig. 34 . 
The first experiment in the culture of "butter bacilli" was made from a specimen of milk which came from South Africa and was exhibited at the World's Fair in Chicago in 1893.

This was named from the scientist who introduced the culture, "Conn's Bacillus No. 4I."

Now there are other varieties which are cultivated for the purpose.

The butter of different countrics varies much like that of different dairies in the same country. Now, any desired flavor may be obtained if a pure culture of the proper bacterium is used and the conditions of manufacture are understood and carried out.

The culture introduced into the cream is known in the Fig. 34. A Bacterium which United States as a "starter."

There are different meth-

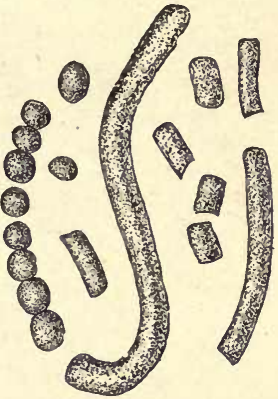
Is Cultivated and Sold to Butter Makers. (After Conn.)

ods of using the starter, but one in common use may be outlined thus: "The pure culture is added to a small portion of Pasteurized milk and allowed to grow. At the right time and temperature a certain amount of this 'starter' is added to the Pasteurized cream." All the factors of success are kept under control ; nothing is left to chance. The extreme meas- 
ures taken to insure cleanliness are a revelation even to the neatest housewifc.

Bad

Not all bad flavors in butter are due to the wrong Flevor bacteria or to molds. The food and physical condition of the cow may affect the flavor of the milk and therefore of the butter, but certain distinctive tastes or appearances, as an oily or soapy taste, bitter or ropy milk, red, blue and other colors in milk, which were

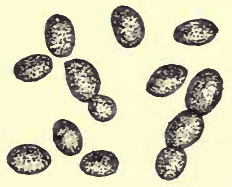

Fig. 35. A Bacterium Which Makea Mill Red. formerly attributed to diet or disease in the cow are now believed to be the work of various micro-organisms. Fig. 35 .

These are diseases in the milk as much as the fermentations in our bodies brought about by germs of consumption or diphtheria are diseases. Both are the work of germs which have gained access through, or are working under wrong conditions.

Health in the human body as well as health in food supplies means conditions unfavorable for the growth of any germs or those conditions favorable only for the growth of helpful forms. For this end the bacteriologist is always working.

\section{CHEESE}

Cheese is made from the casein of the milk and is Cheese a most valuable proteid food. However, it is seldom 
used as food until a ripening process has been carried on which gives it the most desired flavor and increases the digestibility of the albuninous matter by making it easier of solution. The change of the liquid milk into the solid curd is a chemical change, but to numerous species of bacteria and molds we are indebted for the many varied flavors which tickle the nerves of taste.

Certain species grow best in damp, dark caves, and some of the foreign, strong, highly-flavored cheeses are ripened in these caves.

Some s pecies produce large quantities of gas which puffs up the cheese or leaves holes, large or small, few or many, according to the num-

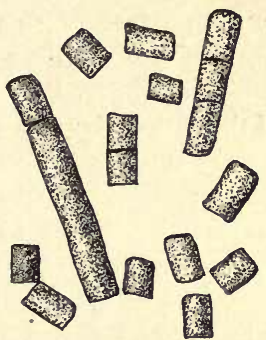
ber of bacteria present. Fig. 36. A Bacterlum Which Fig. 36. Makes "Swelled" Cheese.

In some kinds of cheese, large holes are made in the finished product and mold spores inserted. These grow and give the characteristic flavor to the food. Molds in Ripening This is seen in the "Roquefort" which was first made in a French village of that name from sheep's milk. Brie, Stilton, and Gorgonzola are also allowed to gain flavor from molds, while the Edam is inoculated with a bacterium. Sometimes the fermentations develop poisonous products of putrefaction which may result 
in ptomaine poisoning. This would be putrid cheese. As with cream, so the cheese curd may be inoculated with the particular germ which, by its growth and life processes, is known to give the desired flavor, just as a person may be inoculated with a certain disease germ. In both the processes are similar, although the results are different.

Bacteris Necessary for Flavor

If cheese be made from boiled or Pasteurized milk or from that to which a germicide has been added, the ripening process does not go on, showing that the living micro-organism is necessary to the production of the desired flavors.

Pure cultures are now used for cheese ripening and therefore cheeses that have heretofore been imported, because the species of bacterium necessary was not native to this country, may now be made here when the conditions of growth are understood.

Butter and cheese are possibly the most common foods whose desirable and varied flavors are due to bacteria and molds, but there are others where their work is often productive of a pleasant taste.

\section{VINEGAR}

Anyone who has seen a cider mill in operation in the country or has seen the cider made "while you wait" at a city fair knows the process by which the whole apple is crushed and the juice extracted. Such juice must, of course, be seeded with wild yeasts and with bacteria which were on the skin of the fruit or in the air. When it runs directly from the press, it 
is only very slightly acid, but if allowed to stand for a while it becomes sharply acid. This acetic acid is the result of bacterial growth and finally turns the sweet, pleasant drink into hard cider or cider vinegar. Fig. 37 .

The process of change is a complex one, due to both chemical and bacteriological agencies. When the

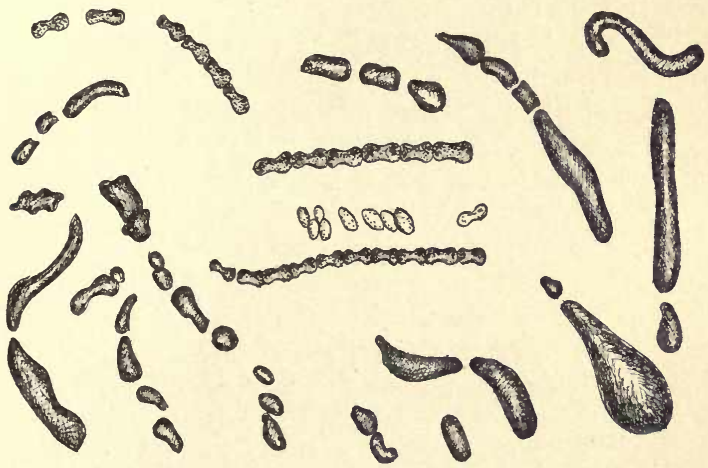

FIG. 37. B.CTERIA WHICH MAKE ACETIC ACID AND VINEGAR. (After Conn.)

wild yeasts have brought about the alcoholic fermentation of the sweet apple juice certain bacteria take up the work and produce acetic acid in a weak solution which we know as vinegar. There are different species capable of producing acetic acid of different strengths and under different conditions. What is known as the mother-of-vinegar is a dense mass of bacteria-a true zooglœa form. Fig. 38 . 
These are the agents which make the vinegar.

Not all vinegar used in the household is made from cider. The large manufactories usually use alcohol or wine as the base of the process. Alcohol and acetic acid contain the same elements in different porportions, the former having less oxygen. The bacteria of mother-of-vinegar are able to take oxygen from the air, cause it to unite with the alcohol, and thus make acetic acid. In actual practice a weak alcoholic solution is allowed to trickle

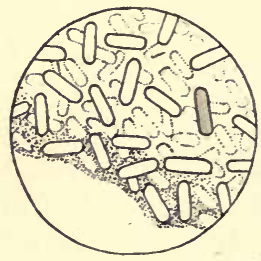

FIG. 38. Bacteria in "Mother-of-Vinegar." slowly over beechwood shavings. In this way a large surface is exposed to the air. It is found that if the shavings are sterilized, that is, if all micro-organisms are removed, no acetic acid is formed, thus proving that here again we are indebted to our dust-plant friends.

Lactic acid, the acid of sour milk, and acetic acid, the acid of vinegar, are two desirable acids due to bacterial growth, while a third, butyric acid, not desirable to the housewife, results when such growth takes place in fats. This is the chief cause of rancidity in butter and other oily substances and the similar taste or smell in old milk. To the housewife this means loss of food supplies and therefore comes under the unfriendly work of dust-plants. 


\section{HARMFUL DUST-PLANTS}

The harmful work of bacteria and molds so far is seen to consist of two kinds, the production of unfavorable conditions in food supplies, and in or on other property, as mildew on clothes, books or furnishings; in short, diseased conditions of our possessions. These diseases, if not cured, may be serious enough to destroy the property, while they may also cause similar diseased conditions in our own bodies, more or less severe, which may result in death.

Bacteria sour our milk, our sauces, our fruit juices; they not only "ret" the flax when we wish them to, but they rot wood when we do not want them to; they make meat putrid and butter rancid; molds spoil our bread and jellies and clothes. All these things the dust-plants will do unless we prevent them, because they are in the world to soften, to decompose, and thus to "get rid of what has ceased to live." All such substances are food for them and feeding is their way of working.

We must know how to prevent their work when it interferes with our interests. We must prevent their growth by removing conditions which are favorable or we must kill them.

An experiment which anyone can try will suggest what favorable or unfavorable conditions are and in what way science seeks to help the housewife to preserve both her property and her health. 
Experiment III. Take seven clear glass bottles,

Experiments Bacteria number or mark each in some way. (Small laboratory flasks with flat bottoms are convenient for this purpose.) Put into each one-half cup or less of milk or grape juice.

Leave No. I open in a warm room, not in direct sunshine.

Fit No. 2 with a full plug of cotton wool about one inch long. Put with No. I.

Have No. 3 like No. I, but place immediately in an ice box.

Drop into No. 4 one tablet or "saloid" of corrosive sublimate. This can be bought of a druggist. Mark it "Poison." Plug like No. 2 and place it with No. I.

Plug No. 5 with cotton wool like No. 2. Put it into a steamer and steam for thirty minutes three days in succession. Place it with No. I.

Fit No. 6 with a tight cork. Remove the cork, but place it with the bottle in the steamer and steam as you did No. 5. Cork each bottle while the steam is coming out. As the cork cools and shrinks, tighten it.

Put a cotton wool plug into No. 7 and heat for half an hour from $155^{\circ} \mathrm{F}$ to $165^{\circ} \mathrm{F}$.

After completed preparation, keep all but No. 3 under the same conditions and note any changes that occur. Test the open bottles with strips of blue litmus paper from the druggist's. See if the contents change the paper any more rapidly or completely after two or three days than at first. Test by smell and taste all 
but No. 4, the one in which was put the corrosive sublimate. This is a poison to human beings when taken internally.

No. I is open to air and dust and in time will become sour or undergo fermentation. If left long enough the milk may putrify.

No 2 is closed to dust but not to air. However, no pains was taken to free the bottle. or plug from the dust which was on them or in the contents, so in time this will become sour.

No. 3 has all the conditions of No. I except warmth, which is favorable, and light, which to some dust plants is unfavorable. It should not spoil or sour as quickly as No. I.

No. 4 has been treated by a chemical which is poisonous and should kill the dust-plants present. This, if strong enough to kill, is a disinfectant. If only strong enough to prevent or retard growth for a while it would be an antiseptic. There should be no change in No. 4 .

No. 5 will have been sterilized, that is, all life within liquid, or bottle, killed by the steaming process. Intermittent The first steaming is expected to kill all the growing or vegetative forms then present. It may not be enough to kill any spores that are there. These will be encouraged to grow by the greater heat, but on the second day they will have developed into the ordinary growing form and the steaming should kill them. That sterilization may be assured and any possibly 
resisting microbe destroyed, a third steaming is given. This is called intermittent sterilization. No. 5 should keep indefinitely. It will, of course, dry away slowly through evaporation.

No. 6 is like No. 5, only closed from the air which passes through the cotton wool, and if the cork was sterilized it is impervious to dust. Some corks are not solid enough to keep the bacteria from growing through the cavities. Such corks need to be dipped in melted paraffin. They are then as tight as a glass stopper. No. 6 should keep, as well as No. 5 .

The woman who put up her grape juice in corked bottles, to find some years after that she had grape wine, either did not thoroughly sterilize the juice, the bottles and the corks, or the latter allowed dust to pass or mold to grow through. She should have covered the corks with melted paraffin to prevent such a possibility.

No. 7 varies from No. 5 only in the time and the degree of heat to which it was subjected. In the case of milk-where the process is most commonly usedthis is called Pasteurization. It is sufficient to kill most if not all the souring bacteria and all the diseaseproducing or pathogenic germs. It does not affect as unfavorably the digestibility of the milk as sterilization, $212^{\circ} \mathrm{F}$, or higher is found to do.

Pasteurized milk will spoil eventually because not all the germs are killed. Pasteurization is valuable for protection from disease germs and to improve the keep- 
ing qualities of milk or cream. As it is not a process of sterilization, such milk sometimes grows putrid or bitter without souring.

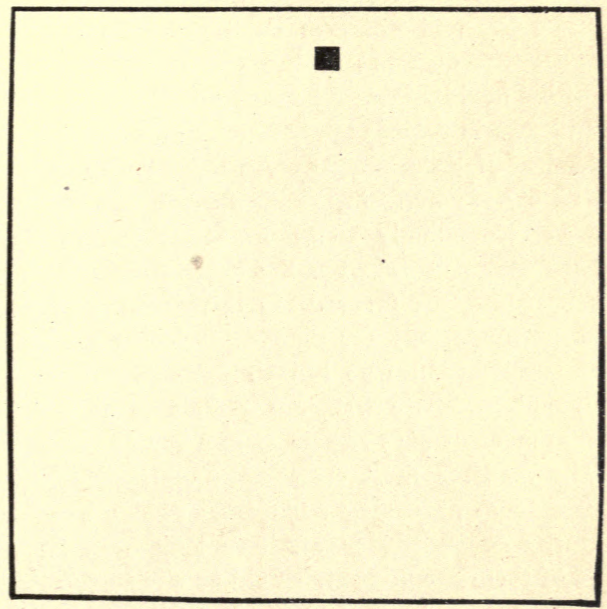

FIG. 39. Diagram Showing Effect of Pasteurization Upon Milk.

Fig. 39 represents the change which takes place in the germ content of milk during this process. If we represent the germ content of a sample of raw milk by the size of the white square, then the black square will show the same after Pasteurization.

All additions of bacterial poisons are liable to injure 
the persons using the milk; therefore, in most cases, such additions are contrary to law.

\section{PRESERVING FOOD}

The following from the U. S. government bulletin on "The Use and Abuse of Food Preservatives," will show us that man has always sought to prevent the use of his food by these micro-organisms:

"In hot, arid regions the question of the preservation of food is of little interest. An animal may be slain and its carcass hung in the air to dry. Other foods keep correspondingly well. Putrefaction and decay are almost unknown. On the other hand, wherever climatic conditions favor decay this question becomes important, especially for those who live at a distance from markets and who kill and preserve their own meat, and for those who, either on land or sea, are for a number of days remote from a source of supply.

"The methods most commonly employed for preserving food, by drying and smoking and with salt, vinegar, alcohol, and sugar, have long been known. Some of them are probably as old as civilization itself, and indeed are not unknown to many tribes of savages. We are told by Herodotus that the ancient Egyptians were conversant with the art of preserving meat with salt, and six centuries before the Christian era Cyrus sustained his troops on long expeditions with salted meat. The aborigines of North and South America were accustomed to cure their meat by smoking or "jerking" (tearing from the bone in long strips and 
drying in the sun), according to the requirements of the climate. The preservation of meat by salting, drying, and smoking is practiced in Oriental countries by a number of the Mongolian tribes, including the Tartars and the Chinese.

"It is a matter of common information that these methods are still employed largely in civilized countries and not alone by those in rural districts who preserve their own meat. Our large packing houses smoke immense quantities of meat with hickory wood. One establishment in Chicago has 43 smokehouses, each of which holds 60,000 pounds of ham or shoulder or 120,000 pounds of side meat, besides II houses of half that capacity. Meat so preserved is recognized as wholesome. It is not always suitable for the sick room, but its taste is a sure indication of its character and the method of its preparation. This makes it impossible to mistake these products for fresh meat, and thus removes the great temptation to fraudulent practice that attends the use of tasteless preservatives. The preservation of meat by freezing has always been practiced, and in localities where the temperature favors this method nothing else is to be desired. Until recently, however, this method has necessarily been of limited application. ***

"No tasteless food preservative has been suggested which is entirely nontoxic, and which does not have a marked influence on digestion, even when taken in

No

Tasteless

Harmless

Preservative relatively small doses. Some there may be whose anti- 
septic action is so slight that food treated with the minimum amount necessary for its preservation is not unwholesome for adults in normal health. But in any case food so treated should be plainly labeled with the name and amount of the added preservative."

Sugar

Condensed milk keeps because most of the water has been taken out and a large percentage of sugar added. This results in a thick, pasty mass, enclosing very little air, in which the few germs which survive the heating that the milk undergoes cannot grow and work. Decomposition is thus retarded or prevented so long as the milk is not exposed to any fresh deposit of dust. The contents of an open can will soon show" mold or give other evidence of spoiling and when diluted to the consistency of ordinary milk will sour like fresh milk.

Drying

Fifty years ago the country housewives dried their own apples, p'r1ms, raspberries and blueberries for winter use. This drying of uncooked fruits is simply an antiseptic measure and they must be kept dry or they will spoil. They must also be carefully cleaned before use. Some of the germs are killed by the drying process, but others enter the spore stage and are ready for work when moisture is furnished.

The present-day housekeeper owes much of the variety in her food supply to the possible preservation of fruits and vegetables through sterilization. "Canned goods" are sterilized by means of steam or boiling. The same process, of course, cooks the food, thereby 
killing any bacteria or other germs which might be in the vegetable or animal tissues. The cans are sealed while hot.

In the household similar processes are carried on. To insure success, everything which touches the food should be sterilized-the jar and its cover, spoons, ladles or funnel. Hands and towels should not touch the edges of the mouth of the jar nor the inside of the cover, for they may carry dust enough to reinfect the fruit.

When the canned food ferments or spoils it means that in some way it was not thoroughly sterilized or - that dust-plants gained access to it afterward. Where sugar is used it should, of course, be put in before the sterilization, not afterward, unless it is made into a syrup and sterilized by boiling. If the housewife remembers that everything is dusty; that dust means dust-plants; that dust-plants mean the germs of fermentation and putrefaction, or "spoiling;" that nothing short of sterilization will insure indefinite "keeping," she will know with what she is dealing and may act intelligently.

If all dust could be removed from the air, the latter might have free access to her cans and no souring would follow. They might dry up, but they would not "spoil." If the jar of food be completely sterilized, it can be stored anywhere in light or dark, warm or cold places; no fermentation occurs. But the chances of partial sterilization-a misnomer, of course, for such

"Spoiling" 
a condition is not one of sterility-are so many that the cold place adds the antiseptic "ounce of prevention." So far as the bacteria are concerned, in the sunshine would be the best place to keep such stores. This, however, would in time fade the food and under some conditions would help to dry it, or crystallize the sugar. Here, as elsewhere, there must often be a choice among unfavorable conditions.

Acids as

Some food supplies, like rhubarb, are so strongly acid that bacteria will not grow in them. This is sometimes canned in cold water with no cooking. Tomatoes and cranberries are sometimes canned in this way.

Bactcria do not like strong acids, so the housewife saves her cucumbers, tomatoes, etc., by making them into pickles. These, however, will mold.

Essential

The essential oils, as clove, cinnamon, mustard, etc., are antiseptic in their effects. They possibly lend their aid in the preservation of the fruit as well as in adding flavor. Mustard, especially, has strong disinfecting properties. Perhaps this is its greatest value as a condiment, for it may act upon the bacteria liable to cause fermentation in the digestive tract.

Salt

Strong solutions of salt prevent the growth of bacteria. Common salt, both in brine and as powder, is perhaps the oldest preservative, and although it makes most food stuffs less digestible it is probably the least harmful of any antiseptic substances. This cannot be said of borax, boracic acid, salicylic acid, the sulphites and formaldehyde (formalin); all of 
which when strong enough to hinder the growth of bacteria are thought to interfere more or less with the digestive processes of man. The use of any such substance is prohibited by the U.S. pure food law.

It would seem that eggs at least should be free from bacteria because of their enclosing shells. But experiments have shown that the newly-laid egg is sometimes infested with bacteria and their growth may bring about the decomposition of the egg.

The more common danger, however, is that of unclean conditions of nest or storage. The shell is porous to air and also, it has been found, to certain bacteria. The shells, then, should be clean. Eggs are often preserved by a coating of shellac or in lime water. These methods exclude air, without which any germ inside cannot grow, and they prevent any germ on the outside from passing through the shell.

We see, then, why eggs should be kept in a clean, cool place, and if packed, the packing boxes or material should be clean. Eggs are often tainted by moldy packing boxes, sour hay, or dirty straw.

Some of the less common acts of bacteria are interesting even if we suffer by them.

Fig. 49 shows a plate which was placed on the outside sill of a second-story window on the back of a city house. This window overlooked an open field bordering on a large body of water. It was not, therefore, an especially dusty position and the day was quiet, with little wind. The fact that so many dust-plants were

Dust Garden Planted Out of Doors 
caught in the twenty minutes' exposure shows the condition in which uncovered jellies, puddings, sauces, etc., are likely to be when placed in such places to cool ; therefore, it is not surprising that lemon jelly, jellied meat, etc., are sometimes found in a liquid condition in such a place.

As we have said, some of the bacteria are capable of liquefying gelatine. If the right species of bacteria had happened to be present in the dust which settled in this place, nothing could have prevented the gelatine being liquefied, because the presence of the liquefying bacterium would have been unknown until its work had been done. A slight liquefaction is shown at the largest spot in Fig. 46.

The teacher who followed a lesson on the dangers of dust by one on lemon jelly which she placed uncovered in the open window to cool, did not apply the scientific knowledge which she had. If she had done as well as she knew, the contents of her mold would have remained jelly and not become lemonade. 


\section{DISEASE GERMS}

We have seen that these dust-plants may spoil our property and thereby cause us much expense. Did they do nothing else, we might not spend so much time or labor in studying them and their work.

Just as among the hundreds of beautiful flowers in the woods and fields there is a "poison dogwood;" or

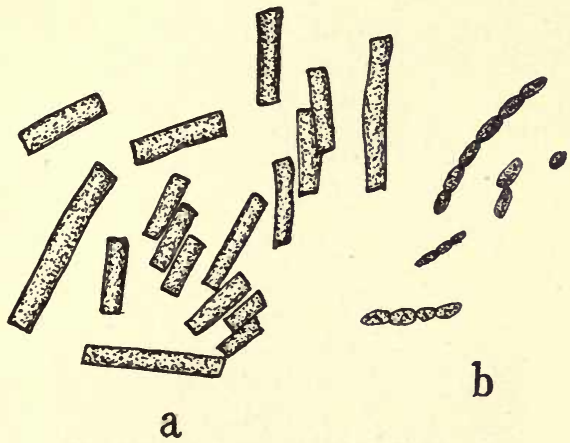

FIG. 40. THE BACILLUS OF TUBERCULOSIS.

(a) Taken from lung tissue. (b) As sometimes found in the sputum.

among the luscious mushrooms a deadly "Amanita;" or as in a great city among the thousands of honest, harmless, law-abiding citizens there is an occasional thief or murderer; so among the millions of helpful bacteria there are a few which in man and animals cause disease of greater or less virulence.

These are called infectious or contagious diseases. They are carried either by actual contact with dis-

Communicabio Diseases 
eased tissues; by inhaled dust, as most often in tuberculosis or consumption; or by food or drink in which was the germ which is capable of causing a specific disease-as typhoid fever, diphtheria, etc, or through some wound in the skin. Figs. 40, 4I, 42.

No Germs Ho Diseaso

If the specific germ of typhoid fever, tuberculosis or pneumonia, etc., is not pres-

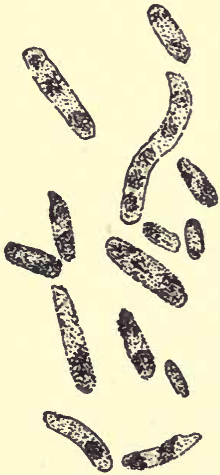

FIG. 41. Bacllius of Diphtheria. (After Conn.) ent the disease will not appear, no matter how "run down" or "below par" the person may be. But any condition short of normal health-any weakening of the body by cold, indigestion, fatigue, overheating, lack of nourishment, etc., tends to lessen: the resistance in some part or the whole of the body and makes the attack of any germ which comes along more surely successful.

Any inherited weakness, as weak lungs, sluggish circulation, imperfect digestive powers, increases the danger or liability to

attacks of germ diseases. Given the germ under favorable conditions for its growth, it is then a question of the resistant power of the individual, aided, perhaps, by medical science, whether the body or the disease will gain the victory. 
It is bulieved by some scientists that the commonly prevalent species of bacteria, harmless under ordinary conditions, may change their character when settled in thickly crowded centers of population where darkness, dampness, bad air, insufficient or poor food make filthy habits of life. If these then gain access to human tissues they may develop disease-producing power and be carried far and wide. In this way cholera, the "plague," and similar diseases, beginning in countries or sections of cities where human beings herd together with no pretense of cleanliness, are carried across seas and continents. This would show how necessary to the physical health of the world is the purification of "the slums," whether these occur at home or abroad. Other bacteriologists deny this hypothesis, but however the disease germs may

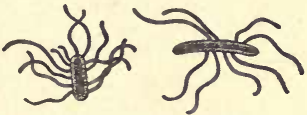

FIG. 42. Typhoid Baclllus Showing the Many Cilla.

(After Sedgwlck and Wilson.) have leveloped their evil ways, they never, so far as we know, reform of their own accord and become harmless, although unfavorable conditions may weaken their power or virulence.

The bacteria which are the cause of typhoid, diphtheria, or tuberculosis make a specialty of this work.

Breeding Ground for Germs The true parasitic disease germs affecting man must have human beings in which to propagate with any degree of success; so the human body is the chief natural breeding ground of contagious disease germs.

Origin of Disease Germs 
Outside of the body disease producing bacteria may remain alive under very varying circumstances, but as a rule they do not multiply as most of them require a temperature equal to that of the body. There are exceptions, as, for example, the growth of the bacteria of typhoid fever in milk, and many others which reproduce in the laboratory under artificial conditions. The lower animals may serve as a breeding ground for some of the disease germs dangerous to man.

Point of

Attack

Method of Infection

Precautions

For most of these germ diseases there is some special portion of the body which is more susceptible than any other. We associate pneumonia and usually tuberculosis with the lungs, diphtheria with the throat, typhoid fever with certain parts of the intestines. From these most usual points of attack may be inferred the most common methods of infection.

When the seat of the disease is some portion of the respiratory system-nostrils, throat or lungs-it is probable that dust entering with the inhaled air carried the germ, or it came by contact with the lips, as in kissing; when it is in the digestive tract, that food or drink was the vehicle; or when in the skin or outer tissues, that there was actual contact with the germ either as dust, dirt, or germ bearing material from a previous case of the disease, which gained entrance through some puncture or a break in the skin.

When we remember that all such diseased conditions due to germs are infectious, we shall exercise great care in preventing contact with the diseased 
part or with articles which have come into contact with it. It should prevent the use of the mouth as a "third hand" for holding miscellaneous articles; the moistening with saliva of envelopes or of fingers to turn leaves, etc., which thence may carry infection to the next user. We should think of the danger to others as well as to ourselves.

This is one of the objections to a common comb and hairbrush, towel, etc. All ready-made garments worn next the skin should be washed before wearing. All garments made under "sweatshop" conditions should be avoided, because of the danger of contagion, if for no other reason. Clothes subject to any infectious discharge, as handkerchiefs, towels, etc., should not be washed with other clothes. When possible, all such discharges should be received upon paper or cloths that can be burned immediately. It is well to take this much forethought for the laun dress.

Especially with such diseases as tuberculosis, pneumonia, and diphtheria, absolute care should be taken that the sputa or discharges from the nostrils and Discharges throat as in sneezing or coughing, are not thrown off into the air to become a part of the common dust. When the person himself is able to control the discharge he should remember that he may thus re-infect himself and also spread the disease.' Infected or soiled articles should be immediately disinfected, burned, or boiled. If this cannot be done at once, 
they should be kept wet, then the germs cannot easily be spread about except by flies.

An exception to the usual characteristics of disease producing germs is a bacillus which is common in the soil of certain localities,-the germ of the usually fatal disease known as tetanus or lockjaw. Fig. 43. The living germ or its spore is carried into the warm, moist tissues through a wound in the skin. This usually is made with some sharp object which has come in contact with the ground, as a nail, a rake tooth,

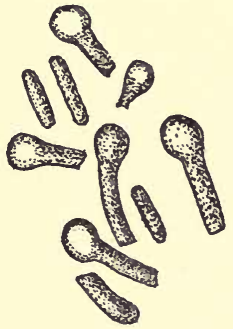

FIG. 43. The Baclllus of Lockjaw. a pitch-fork, or a dirty knife. It has been known to follow the bite of an insect. Unlike most disease germs, this bacterium forms spores which makes it very tenacious of life. Its spores will resist boiling or drying for some time. It is said to have been found in gunpowder which would account for the many cases of lockjaw resulting from gunshot wounds. As a result of celebrating the Fourth of July in 1903,415 deaths from lockjaw occurred in the United States. This number dropped in 1904 to 105 , in 1905 to 104 , and in 1906 to 89 . This decrease was brought about through the proper care of wounds and the use of tetanus antitoxine. Wounds should be cleaned thoroughly and not bound up tightly, as the 
exclusion of air favors the growth of the tetanus bacillus. Its characteristic spore at one end of the rod has given it the name of the "drum stick" bacillus.

In general it may be concisely stated that infection comes through inhaled dust and that "Food and fingers are the carriers of contagion," as Dr. William T. Sedgwick has so often proved.

The disease bacteria effect their dread results in various ways; sometimes the tissues are actually destroyed, as in tuberculosis, but in most cases the products of the life growth of the germs cause the disease. These products are poisons which are known under the general name of toxines.

Whether in the future the germ theory will be found to explain all diseases we may not now say, but indications point that way. The latest "discovery of the germ of smallpox," if established, is a stimulus to increased efforts along such lines. Animal and vegetable forms are both proved guilty before the bar of the scientific investigator.

The germ of typhoid fever grows well in milk. The germ may enter the milk as dry dust from any one of many contaminated sources, or through water in which the milk-containing vessels are washed. In cases of dishonest milkmen, from the water used to dilute the milk. Numercus epidemics of typhoid fever have been traced to milk as their source, where only those using milk from one farm or from a certain milkman have been affected. 
Infection by Oysters

Sewage

That the germ may retain its vitality through all the processes of butter-making is proved by its presence in samples of butter examined.

It is not aiways easy nor possible to find the source of single cases of this or any disease, for the infectious germ, carried as dust, may lodge on any article and be thus carried to the mouth by food or by hands.

Oysters, fattened on sewage-polluted water, have carried the germ to persons eating them. Clams dug out of sewage-saturated flats, when eaten raw, may carry the typhoid germ in a similar manner.

In country places where wells are the source of drinking water, or anywhere where surface waters are used directly for this purpose, there is great danger of contamination from drainage, either from the house, its outbuildings, the barn, or manured fields. Contaminated water supply is the most common source of typhoid infection.

As the germs causing the disease are thrown out in the discharges from the intestines and the kidneys, these are the sources of infection. If the discharges from the patient and any articles soiled by these are not destroyed by fire or thoroughly disinfected while moist, there can be no surety that they may not, either as dust or through water, carry infection to someone nearby or even far removed. If such care be taken for every case of the disease, it will soon be no more prevalent than smallpox.

Every case of typhoid fever is due to somebody's 
criminal carelessness, because in the eye of the law ignorance is not accepted as an excuse. Somewhere there has been neglect of the cleanness or care which ought to have made infection impossible.

When rain starts from the clouds it is pure, but in falling through the air it washes out from the air large quantities of dust, so that the first fall of any shower is very dirty. Where rain water is collected for drinking or cooking purposes this first fall should be allowed to waste or the whole be thoroughly filtered before its use in cooking. The cistern also must be kept clean and free from dust pollution. It should be sheltered, but not air-tight. Such a water supply is seldom polluted by sewage or any human wastes. It is water running on the surface of the ground or draining through it which may encounter sewage pollution and thus be most liable to take up disease germs.

Snow filters the air even more than rain, each congealed flake usually containing many bacteria. The first snow, although white and pure to look at, is not clean and should not be used as a source of drinking water except in emergencies. However, after the snow has been falling for some time the water from it is practically clean.

Light always retards and in many cases prevents the development of harmful micro-organisms. But this disinfectant action does not extend to all depths, probably not much beyond nine feet, so that its purifying agency in open water supplies is only partial. A water

Pollution of Water
Criminal

Carlessness 
supply which receives any house drainage or that from manured fields is in danger of contamination at any time.

Impure water may be purified from all germs by Filters boiling for half an hour. Such water, having lost the air which was dissolved in it, tastes insipid. The air may be restored by pouring the water a few times from one clean vessel into another, and this should be done in a clean place, that is, where there is little flying dust.

Most filters simply strain out visible suspended matter or invisible but comparatively large animal or vegetable forms. A flannel bag will do this, and it can and should be cleaned daily. It clears currant jelly, why not water? When charcoal forms a part or the whole of the straining medium, more organic matter is removed and therefore more color is taken out, but the charcoal soon loses its purifying power and must be cleaned or renewed. None of the ordinary faucet filters will remove the minute disease germs and thereby make a polluted water safe for drinking. Germ removal requires a very fine medium, which means slow straining. Certain filters, made of very fine unglazed clay or similar substance, take out the germs themselves, but cannot remove the products of their life processes, which are soluble. In some cases these are as dangerous as the germ plant itself. If a filter does strain out the bacteria, then it is evident that the straining medium will become foul with them and 
must be capable of and receive complete sterilization. Any faucet filter which allows a generous. stream of water to issue quickly after it is turned on is practically useless so far as the removal of bacteria is concerned.

A suspected water or one of unknown quality would better be filtered and then boiled rather than boiled and Filter Then filtered, if it needs to be filtered to remove suspended matter. Distilled water or water turned into steam and condensed is a pure water; but to remain so it must be received into perfectly clean vessels and not exposed to dust.

Ice as ordinarily delivered frequently shows three layers. One, usually at the top, the snow ice, is scarcely transparent and when melted shows impurities not visible in the ice. This usually holds many bacteria and should always be rejected. Another layer, partially transparent, is more or less bubbly. These bubbles contain air which allows any living forms therein to remain alive if not to grow. If derived from impure water the bubbles may contain some of the germs which will make the ice undesirable, since many bacteria survive a lower temperature than ice ever attains. A third portion is wholly transparent. This last, the crystal clear ice, is the only ice which should ever be used directly to cool drinking water, for this alone is purified by crystallization although not perfectly.

Ice should always be washed from surface dirt before 
it is put into a refrigerator or in any way used for the storage of food. Safety may be assured if ice is never allowed to touch the food. Its effects can be obtained without actual contact and contact may mean contamination.

The tub of lemonade standing open on the picnic ground or the street corner has sufficient chance of germ infection without a block of doubtful ice in its midst.

THE RESISTANCE OF THE BODY TO DISEASE GERMS

We have seen that many diseases which afflict human beings have been definitely traced to these organic forms; to these micro-organisms found in inhaled dust, in polluted water, in food and on articles which may puncture the skin.

If the avenues of infection are so common, the question naturally arises, how can any human being escape? We know that many do, that there are hundreds of persons who never have had typhoid fever, diphtheria, or other infectious disease; that two persons may, so far as we know, eat of the same food, drink from the same water supply or live under exactly similar conditions-one has some infectious disease, the other remains well.

It is too a matter of common knowledge that a degree of safety from a second attack is often assured to the person after recovery from the first illness. He seems to have some power of resistance which he did not have before and which is absent in his neighbor. 
Yet this safety is not always complete, because some persons have recurring attacks of infectious diseases. This is especially true in diphtheria.

There seems to be some power in the robust, healthy, strong body which is absent in the weak and "ailing" or in the body "below par," as the physicians say. Whatever this power is it may well be referred to as "vital resistance."

Dr. William Sedgwick says, "There is, however, no quantitative measure of vital resistance; but when it is regarded as small or altogether wanting, the term is no longer used, and the organism is said to be not vitally resistant, but "susceptible" or "vulnerable" to disease. $* * *$ When the vital resistance is complete * * * the organism is said to be immune."

At present no one perhaps knows all the factors which go to make up this "vital resistance" which protects one person and is absent in another, but according to Sedgwick, "We may, it is true, safely consider that it is bound up with chemical and physical processes which result in favorable chemical and physical conditions."

In this connection it should be noted that the hydrochloric acid in the gastric juices of the adult is fatal to nearly all of the ordinary bacteria present in uncooked food and to many disease germs. The secretions of the intestines are alkaline and would prove a favorable condition for many kinds did they escape from the stomach. Water passes quickly through the

Vital

Resistance 
stomach and may not mix with the acid juices, consequently it is an especially dangerous medium of infection.

Health

Health means the prevention in all possible ways of any chance of attack from the insidious disease germ, but it means as well the observance of all other laws that tend toward the maximum cfficicncy of the body and mind, so that if the enemy gains admittance it may be routed or its attack made futile.

Theories

of Vital

Resistance

Much has been done along the lines of investigation, yet much of these processes of resistance remain to be proved. A few words concerning the theories put forth by investigators may show our indebtedness to them and increase our own sense of responsibility toward the preservation or return of health.

Leucocyte

Among the red cells which give the familiar color to good, rich blood are other cells known as the white globules or leucocytes. They are very much like the amoeba, the lowest animal known, in that they have the power of independent motion. They are sometimes called "phagocytes," or "wandering cells," because they pass here and there throughout the body, wherever they will. Fig. 44. Their office seems to be a protective one, for they act like the police of a city in protecting the body from bacterial invaders. They are also called "eating cells," for when one finds a bacterium it proceeds to wrap itself about the little plant cell, to poison, if not to kill it; then, loaded with the dead bodies of its victims, it makes its way to some part of the body where the load may be disgorged. 

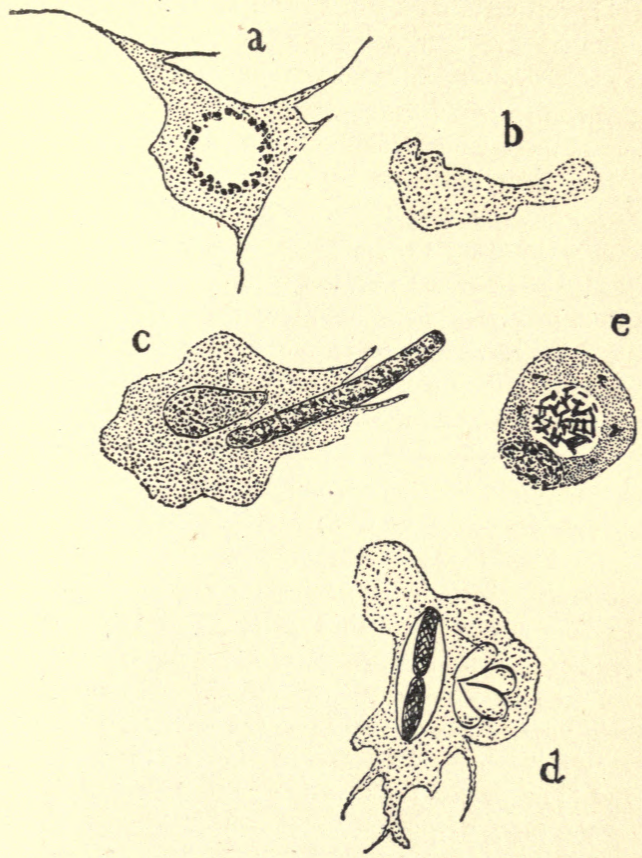

FIG. 44. (a) and (b). PHAGOCYTES.

(c) A phagocyte with partially enclosed bacterium.

(d) A phagocyte with two bacteria enclosed.

(e) A phagocyte with enclosed mass of bacteria. (After Conn.) 
It is fortunate for us that there is such a force that is hungry and ever seeking what and how many it may devour, for we can never know just how much we owe to them for our freedom from disease. As long as these white globules are numerous and active, so long man seems to have one powerful guardian against any invading germ, however poisonous. Anything which affects these white guardians unfavorably lessens their power to protect man.

Effect of Cold

Cold paralyzes them and gives the bacteria, if present, a better chance to escape from being overcome, and we are this more subject to their attacks. Winter's cold increases the prevalence of many germ diseases, not usually by increasing the number or virulence of the germs themselves, but by decreasing in some persons the power of these leucocytes-the guardians of our health.

Insufficient clothing, or insufficient food which is the body's fuel, may thus favor the attacks or the spread of germ diseases. Very often these phagocytes lose their lives in resisting our foes. Then they, with their victims and the dead tissue cells, form pus or "matter," which children even know should be "let out" in order that the tissues may heal.

Formation of Pus

The formation of pus is well illustrated by the action of a sliver. We may or may not know that the tiny speck of wood entered the flesh. But it is likely to carry in with it dirt and therefore bacteria. The phagocytes rally to surround this newcomer. The flesh 
becomes red, inflamed and sore, then a "fester" appears. Open the "fester" and a drop or more of pus exudes, in the midst of which will probably be the irritating sliver. The bacteria, the cause of the inflammation, having passed out, the flesh heals. If there has been much bacterial growth there may be much or longer continued inflammation because of the toxines or poisonous matters produced by the germs.

When certain very virulent germs enter the tissues, are unconquered either by the phagocytes or the other resisting powers of the body, the products of germ growth may be rapidly distributed by the blood throughout the body, producing the fatal cases of blood poisoning. The germ was especially virulent, in great numbers, or possibly neither of these, but the body was so "far below par" that it had no power to resist the growth and action of the germs and the toxines which the germs manufactured.

That bacteria capable of producing disease in human beings are far more commonly present than the diseases cannot be doubted. Germs of pneumonia are found in the mouths of healthy persons. Some persons when exposed to infection succumb; others remain unaffected. The old saying that "lightning never strikes twice in the same place" has often been applied to the expressed fear of a recurrence of an infectious disease. Although there are many exceptions to the rule, it is true, as we have said, that in a majority of cases after recovery from such a disease there is less dan- 
ger of a second attack. There seems to be great differences also between the susceptibility of children and adults to certain diseases.

Effect of Poisoning

The different ways in which bacteria are known or supposed to bring about diseased conditions more or less severe have been described. Whether these causes are the poisonous excretions during the normal life of the bacteria, or are the result of chemical change produced by some ferment which they secrete, the effects upon the blood and tissues are shown by several common symptoms-a high temperature or fever; quickened circulation or rapid pulse; perhaps difficulty in breathing, and pain. There may be local redness, swelling, and finally the formation of pus, or a "gathering" of the protective phagocytes and the broken-down cells of the diseased portion. These local effects may be entirely within the body or they may be show themselves on the outside under or in the skin. In the latter case a prompt discharge of the pus is usually followed by relief. If there be no-discharge and the dead and poisonous matter be reabsorbed into the tissues, there follows a general poisoning of the whole system.

Immunity

Whenever partial or entire immunity seems to be present, we are interested to know in what this immunity consists. Great as is the protective force of the "white guardians" their presence or numbers are not the only factors in immunity.

Metchnikoff, the father of the theory of phagocy- 
tosis-as the protective work of these "eating" and "wandering cells" is called-has said that "immunity may be inborn or acquired." * * * The former is independent of the direct intervention of human art; the acquired immunity nay come as the result of the spontaneous cure of an infectious disease or as the result of direct interference of human art, as in vaccination and similar methods now employed by physicians to ward off an expected disease or to decrease the virulence of one already contracted."

This inborn immunity Newman calls "natural immunity" and attributes it to the presence in the blood of soluble matters called alexines. If the alexines are present in sufficient quantity, the person is less or not at all susceptible to certain diseases, although they may not protect him from the attack of all disease germs. These alexines protect the body perfectly from all but the pathogenic bacteria.

Phagocytosis seems to be a plausible theory so far Toxine as the germs themselves are concerned, but does not prove equally tenable in the case of the toxines which the germs have produced. Other investigators, notably Behring and Kitasato, do not believe that the phagocytes are the prime protective ageney in this immunity. They discovered in their experiments upon animals that the clear, yellowish liquid part of the blood, or the bloom serum, taken from an animal that had diphtheria could and did in their test tubes destroy the action of the toxines of that disease. 
Antitoxine It seems, then, probable that in the blood serum of immune persons there may be another factor in the vital resistance. That is, the body cells in some way manufacture substances that neutralize the poisons or toxines produced by the germs, thus enabling the body to expel the germs themselves, and recover. These antitoxines or the power of producing them may remain and the body becomes immune to the disease. These antitoxines are specific in nature,- that is, are capable of neutralizing the toxine of only one kind of germ.

Acquired Immunity

Immunity may also be "acquired" by the injection into the blood, in some cases, of the germs themselves, as in the case of inoculation for small pox as was as was originally done in the case of inoculation for small pox. Formerly some "matter," that is, the infectious material, was taken from a person sick with small pox and injected directly into another person by placing it under the skin, where it quickly affected the whole body.

Vaccination Jenner-a celebrated doctor in England about I796 -first modified inoculation by introducing the "matter" into healthy calves or cows. These animals being very susceptible to the disease, contracted it, and then from the pustules of their bodies the "matter" or "vaccine" was drawn and injected into human beings. This, in man, was found to produce a milder form of the disease and to leave in the system upon recovery something which gave immunity or protection from small pox. 
Vaccination or Jenner's process is still the recognized preventive or protective measure, and it has reduced small pox from a dread pestilence to a disease producing fewer deaths than measles.

The great Pasteur reasoned that "if an infectious disease be really a struggle for supremacy between man and microbe, it is probable that in vaccination for small pox the struggle is less severe for the patient, because the germs of small pox have somehow been weakened or enfeebled by their residence in the cow."

The use of antitoxine for the prevention or treatment of diphtheria is perhaps the best example of that method of producing immunity. In this case the horse is chosen as the intermediate host for the production of antitoxine material. The toxines, or sometimes the germs themselves, are injected into the body of the healthy animal. The first dose is usually a small one. A slight reaction or fever may be noticed. The doses are gradually increased until the animal is found to be immune. Blood is then drawn from this immune horse and "its serum is found to contain the antitoxine in abundance."

Some of this serum is then injected into a person who has been exposed to, is likely to be, or is Diphtheris ill with the disease. In the last case, to be effective, the antitoxine must be introduced at an early stage of the disease when there is not too much toxine to be neutralized.

By the use of antitoxine thus obtained, the mortality 
from diphtheria has been reduced over one half. Its effects as a preventive measure and in lessening suffering "have everywhere been most significant and encouraging." Antitoxines for lockjaw, for snake bites and for some forms of blood poisoning have been produced and are used with more or less success.

Constant efforts are being made to find an available antitoxine for every infectious disease. Many difficulties present themselves, because the same germs do not always cause the identical disease when introduced into the bodies of the lower animals that they produce in the body of man.

\section{SANITATION}

Nature's Disinfectants

As sunshine and pure air are Nature's free disinfectants, their presence in the house is the greatest preventive measure of all sickness due to micro-organisms. They, then, are the foundation requirements for cleanness, because this means so largely the absence of dust-plants.

Conditions in the House

Inside our houses there can never be the same amount of sunshine and fresh air that proves so efficient out-of-doors. The house, too, must be dry, and therefore dust cannot be held as it often is out of doors on damp surfaces. However, the absence of winds inside makes possible, after a little while, a comparatively dust-free air, because the heavier particles which carry the bacteria and molds will settle on all surfaces, chiefly on the horizontal ones, as floors, 
chairs, shelves, etc. Figure 45, redrawn from Dust and Its Dangers, T. Mitchell Prudden, shows how the living plants attach themselves to the other particles of dust ; $a$ is a small bit of wood carrying four different
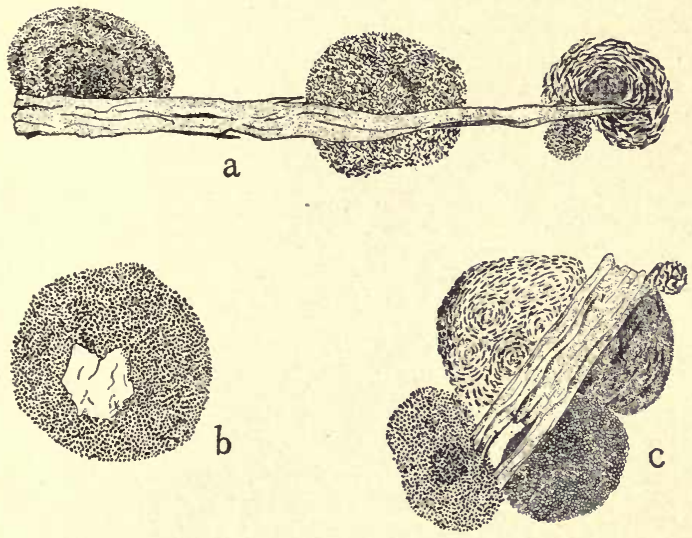

\. 45. COLONIES OF BACTERIA GROWING ON DUST PARTICLES. (After Prudden.)

colonies; $b$ is a grain of sand surrounded by one colony; $c$ a splinter of wood, is loaded with five different species. Each of these colonies is the growth of five days from a single germ which fell on the surface of the gelatine. At the end of five days the largest was only just visible to the naked eye.

If a dust-garden be planted immediately after sweeping 
sweeping a carpeted room and another when the same room, with closed windows, has been left undisturbed for two or three hours, there is a marked difference in the number and kind of colonies which will grow.

Dust Gardens

Figures 46 to 49 inclusive are photographs of "dustgardens" planted in various places by different persons under varying conditions. The plate shown in Fig. 46 was planted after a carpet had been swept with a dampened broom. The plate was left open ten minutes.

The damp broom caught and held much of the dust which would have been thrown into the air if a dry broom had been used. If the sweeping had been donè carelessly without thought of the dust, many more plants would have found their way to the garden plot. As it was, the number of spots shows how carefully sweeping ought to be done in order that the air may not be charged with dust which is thereby simply changed in place, not removed from the room. It soon returns to the floor or carpet.

Plate Fig. 47 was exposed for ten minutes in the same place after the room had been quiet for three hours and the dust had therefore settled considerably. The fewer spots show that the air had become much freer from dust than when Fig. 46 was planted.

Settling of Bacteria The greater number of molds present in this plate shows that the bacteria, being heavier, settle first. The presence of so many molds shows that even after three hours' quiet, the air may still be sufficiently 


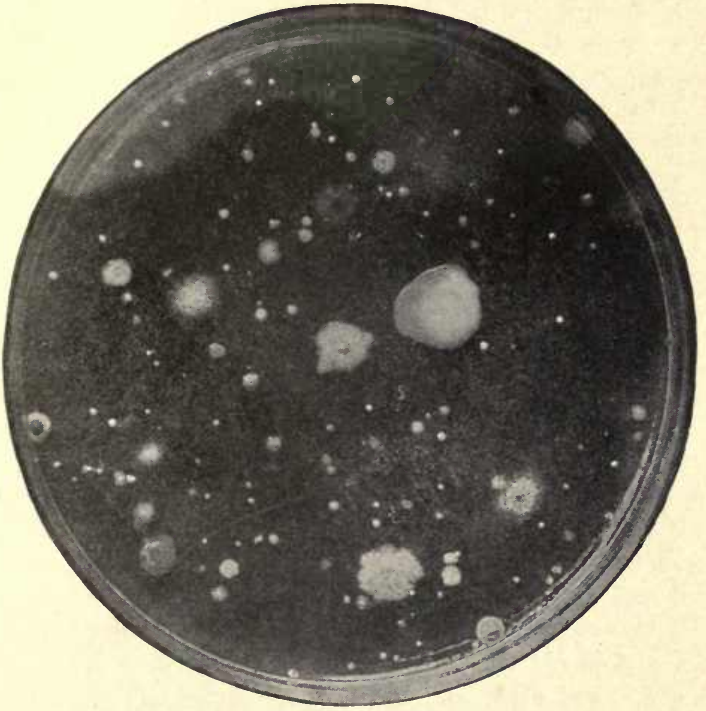

Fig. 46. A PETRI PLATE PLANTED IMMEdIATELY AFTER THE SWEEPING OF A CARPET. 
charged with dust to cause trouble if food is uncovered.

Many interesting experiments have been carried on in hospitals to find how long it takes for the bacteria to settle out of the air of the wards after the daily routine of cleaning and care is over, or at night.

In the Boston City Hospital* it was found that about midnight after the wards had been quiet for some hours the bacteria had nearly all of them settled upon the floors, beds, or other articles of furniture. As soon as the work of the day begun many of these, of course, were again thrown into the air. Dr. Tucker found that sweeping nearly doubled the number of germs found in the air.

In some experiments reported by Dr. T. M. Prudden $\dagger$ it was found that in a carpeted living room 75 bacteria and I mold settled on the surface of the exposed plate in five minutes before sweeping, when the room was still. Immediately after sweeping, a similar experiment showed over 2,700 bacteria and 6 niolds.

Other experiments have compared the numbers found in a certain quantity of air taken from houses considered clean and those called dirty. The latter showed about six times as many bacteria as the former.

Compare Fig. 46 with Fig. 47 and decide the ques-

*Report of State Board of Health of Mass., 1888.

†Dust and Its Dangers, T. Mitchell Pruden. 


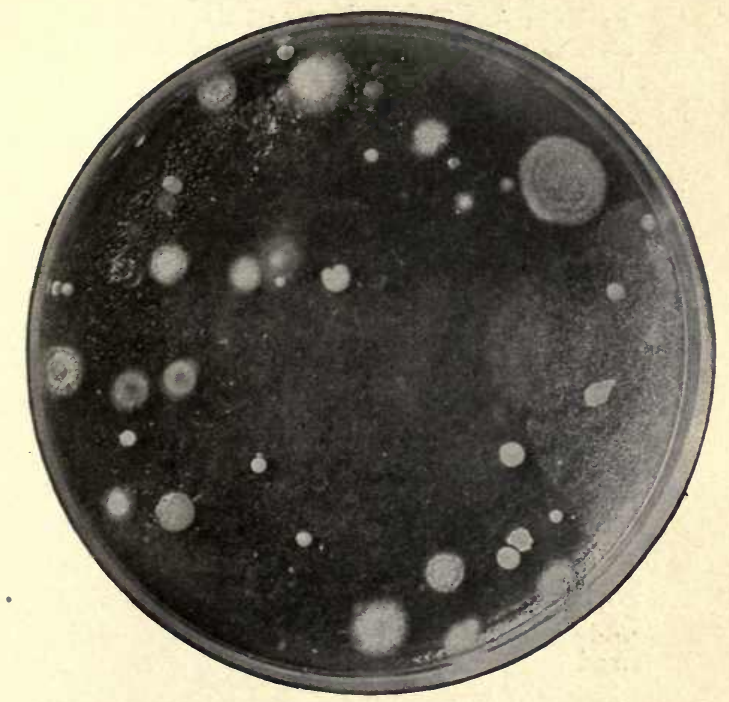

k. 47. THE SAME AS FIG. 46, AF'TER THE DUST HAD SETTLEU THREE HOURS. 
tion when dusting should be done, if the aim of dusting be to remove dust from the house. If, then, these and other experiments have shown that at least two hours are required to free the air of a still room from the bacteria present in its dust, it is of little use to dust immediately after sweeping. When this is done, no wonder the housewife exclaims in despair, "Why, this room was dusted this morning, but you never would have known it!"

While we cannot always let two hours elapse between some dust-spreading process of housework, like sweeping or bedmaking, we can remember that the raised dust must settle before we can remove it. Wait as long as possible!

When Fig. 46 is compared with Fig. 47, the reason is plainly seen why rugs mean less dust than carpets and therefore a cleaner, healthier house, because these can be carefully rolled, cleaned out of doors, and the floor wiped with a damp cloth.

Bod-making

Next to sweeping as a dust-raising and dust-spreading process comes bed-making.

Fig. 48 shows a plate planted just after a bed had been made. The colonies of bacteria and molds in this plate had been growing for a longer time when the photograph was taken than in plates Fig. 46 and Fig. 47. Two of the molds on this plate are very mature, being black with spores.

As health requires that the air of the sleeping room be as free from dust as possible, considerable time 


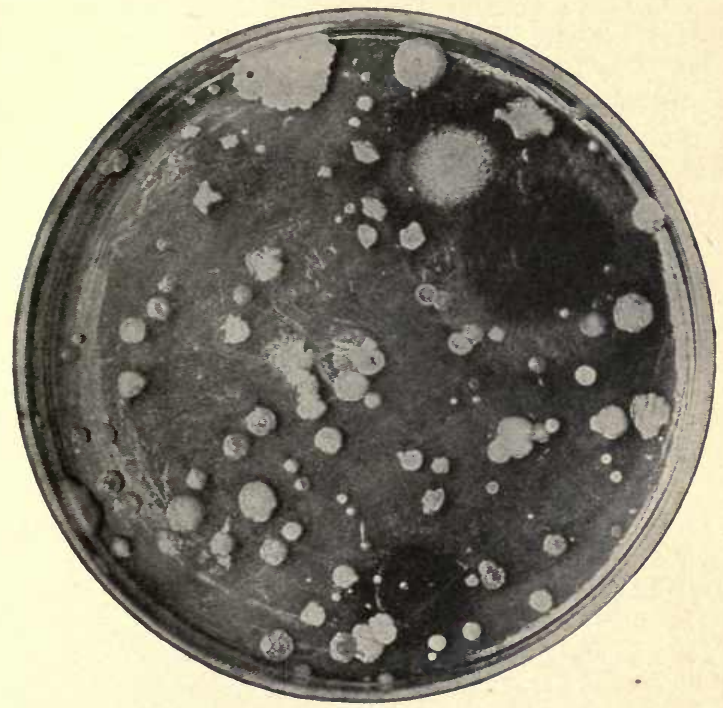

FIG. 48. DUST GARDEN PLANTED IMMEDIATELY AFTER BEDMAKING. 
Removing

Dust

should elapse after bed-making before the dusting is done.

To have a clean house, great attention must be paid to the removal of dust, or dusting. In houses where this is done with a feather duster, bed-making gives up its second place to this dust-spreading, never a complete dust-removing process. Dusting should always be done by wiping up the dust into a cloth. Whenever possible to do so without harm, the cloth should be slightly dampened or oiled. Dust-plants are held by damp or oiled surfaces.

If, then, the bacteria do settle from the air on floor and furniture, and in still places about two hours is necessary to effect this comparative clearing of the air, these facts are surely indicated:

FIRST. Sweeping should be done in such a way as to raise as little dust as possible into the air.

SEcond. Dusting should never follow immediately after sweeping.

THIRD. Dusting should be a process whereby dust is taken out of the room, not stirred up and thrown again into the air. Cleanness does not result unless the dust is removed from the house.

Burn

Bweepings Wash

Dusters

Cover Food

All collections of dirt from sweeping should be burned, and all dusters should be washed. "Burn the sweepings" and "wash the dusters" are two orders which the intelligent housewife will obey.

Dust in the air settles on food and thus produces decomposition. Food then should be kept covered as 


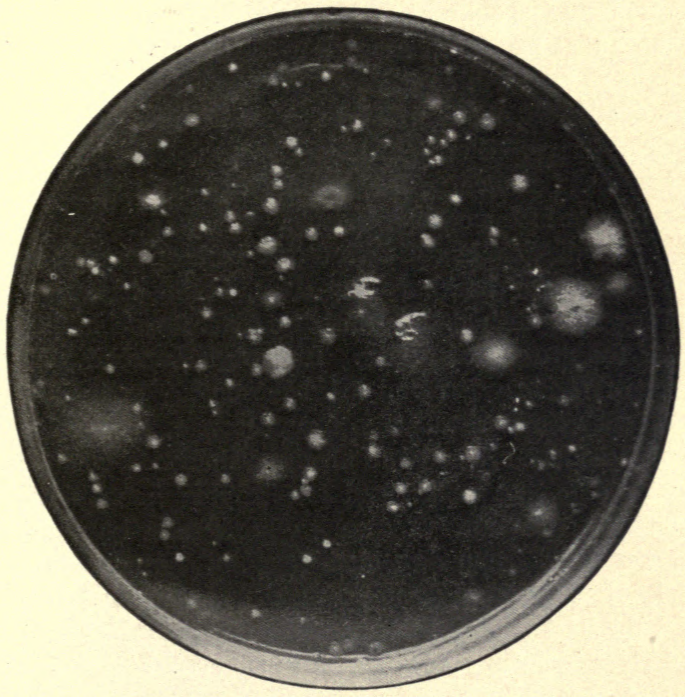

FIG. 49. DUST GARDEN PLANTED OUT OF DOORS. 
Brush Clothing

Deadly Dish-Cloths

Care of Plumbing

much as possible, cold and dry as feasible, to retard the growth of the micro-organisms present. All foods eaten raw should be thoroughly cleaned, especially those that have been exposed to dust, those grown in or near the earth or those watered by house slops.

Clothes should be well brushed, out of doors if possible; those which can be should be washed frequently, boiled and sunned. All should be kept dry to prevent mildew, which we know is mold.

That dish cloths and dish towels be kept clean is as necessary for health as for clean, bright tableware. The greasy dish cloth furnishes a most favorable field for the growth of germs. It must be washed with soap and hot water and dried thoroughly each time. All such cloths should also form a part of the weckly wash and be subjected to all the disinfection possible with soap, hot water, and long drying in sunshine and the open air. Beware of the disease-breeding, greasy, and damp dish cloth hung in a warm, dark place! Indeed, no damp article should ever be stored in the dark. The ordinary sink cupboard is a warm, dark and usually a damp place, which even the plumber denounces as an unclean spot.

All waste and overflow pipes, from that of the kitchen sink to that of the refrigerator, become foul with grease, lint, dust, and many organic compounds that are the result of bacterial action. They are sources of contamination to the air of the entire house and to the food supply, thereby endangering health. 
The germs of putrefaction abound in dark places and the air becomes stagnant and impure.

As the schcolroom bears very close relations to the home, the conditions there should be thought about by the housewife. Either from lack of time or money, wrong methods, or too few employees, the so-called cleaning of many schoolrooms consists in a vigorous sweeping with dry broom or floor brush after school at night. The dust settles during the night, but in the morning, instead of being taken away on damp or oiled cloths, it is stirred into the air again by the whisking feather dusters.

At nine o'clock, in troop the children, with warm, moist throats, eyelids, and nostrils all ready to catch the floating germs which should have been removed.

The housekeeping of schoolhouses needs intelligent supervision as well as the mental and moral equipment of their inmates. Where so many persons are gathered from many kinds of homes the danger from the presence of disease germs must be greatly increased over that of the private house.

In dirty schoolrooms, poorly ventilated by windows and doors, compared with well ventilated rooms, the proportion of bacteria in the same volume of air has been found to be sometimes as great as si- to one hundred.

The cleaning and cleanness of schoolrooms should certainly interest mothers, next to that of their own homes. This may be their first civic duty.

Cleaning School Room: 
Sanitary cleanness requires the cleanness of the individual, of his possessions, and of his environment. Each individual is directly responsible for his personal cleanness and that of his possessions; but over a large part of his environment he has only indirect control. Not until this personal responsibility is felt in its fullest sense, and exercised in all directions toward the formation and carrying out of sufficient and efficient public laws, will sanitary cleanness supplant the cure of a large number of diseases by their prevention.

When the right of cleanness is added to the right to be well fed, and both are assured to each individual by the knowledge and consent of the whole people, then the great gospel of prevention may make good its claim. Towards this ideal tend all the problems which the science of bacteriology is endeavoring to solve. These problems cannot be solved in the laboratory alone. Each house in the land, presided over by an active, intelligent supervisor, should become an experiment station for the individual application of scientific laws. 


\section{HISTORY OF BACTERIOLOGY}

The science of Bacteriology is still young, and like normal youth is marked by constant, vigorous growth, yet the micro-organisms with which it deals are veritably antique, for the following quaint observation is said to have been made two thousand years ago: "It is to be noticed that if there be any marshy places, certain animals breed there, which are invisible to the eye and yet, getting into the system through the mouth and nostrils, cause serious disorders."

Later on when the early scientists were looking through their very imperfect lenses at certain liquids, they saw many hardly visible moving bodies. They said, "Surely these moving things must be alive," and as they had not put anything into the liquids, it was natural to conclude that the little forms must have been spontaneously generated. So great a thinker as Aristotle had previously made a similar statement, for when he saw birds one morning flying about over the valley of the Nile, where the day before not a bird was present, he devoutly concluded that they must have been generated from the mud of the Nile, that great Father of Plenty. It is within the memory of some living today that this theory of spontaneous generation was still believed.

About 1675 Leuwenhock, the son of a Dutch lens grinder, saw through one of his lenses in a drop of stagnant water minute moving forms. Soon some of the scientists became interested and studied these "animalcules" or little animals, as they were called. They

Spontaneous Generation of Life

Animalcules 
made drawings of what they saw, which show very much the same forms that would be seen today under similar conditions. Many scoffed at these reports, intimating that such observers were not wholly sane.

Early

The processes of fermentation and putrefaction very early excited investigation. Great efforts were made to find out their cause. For years the oxygen of the air was thought to be the agent, and even today many a housewife will tell you the jar of fruit spoiled because "the air got into it." The dust-plants which are in the air, the real cause of these changes, could not be discovered until the compound microscope brought to view the hitherto invisible life which swarms in all fermenting and putrefying matter.

The compound microscope was invented in the early part of the seventeenth century, by whom is not known. It was not brought to its present simple but effective form until about sixty years ago.

One of the first sources of bacteria for these early investigations is still a common and sure source.

Take a wisp of hay and soak it in lukewarm water for a day or so. The result is a brownish liquid looking much like tea, which it is, being an infusion of hay. Thoreau called this "meadow tea." A drop of this under the microscope furnishes a lively menagerie, as well as numerous bacilli. The hay is dusty; in the dry dust are spores of bacteria which under the influence of the warmth and moisture become once again active forms and can be seen to go through all their life processes. 
A drop of water from the neglected vase of flowers will often give similar interesting phenomena.

The modern work upon bacteria was begun and the foundations of the science of Bacteriology were laid Work of Pastour when Louis Pasteur in France, less than sixty years ago, began to grow and cultivate these dust-plants. Since then the advance in knowledge about them has gone on with ever increasing rapidity.

If it is possible to increase the power of the microscope or to so train the human eye that it may see more than is seen at present, would greater wonders be revealed? Such a possibility is ever before the enthusiastic student.

About twenty years after Pasteur, Robert Koch declared that he believed bacteria were the cause of disease and not the effect, as many had thought them to be. He began to grow bacteria on potatoes and in other ways then new, but now common. These are known as "solid cultures."

This was a great advance toward the discovery of disease germs, because by the differences in their behavior or growth on different substances it was possible to separate the species.

- The farmer knows that the same soil is not equally good for corn and melons and that a pine tree will flourish where a willow would die. These are at the other extreme in the plant world from the invisible bacteria, but the microscopic forms have their preferences in food and their favorable and unfavorable conditions, as well as their well-known giant brothers. 
Mothod of Study

Bacteria Clasued as Plants

Founding of the Science

By finding what they grow on and their behavior in different soils; what they like best to eat; what temperature is most favorable to reproduction; adding to this the knowledge of structure, motion, and form which the microscope reveals, and lastly by chemical analysis of the substances produced by them during growth the species are determined.

These methods have also made possible the cultivation of pure cultures which are highly desirable with all species of commercial value. A pure yeast makes possible a saving of thousands of dollars in the brewing industries alone, and some time, let us hope, the housewife may be able to buy pure yeast for her breadmaking.

It was not until 1850 that these organisms were studied as plants. Dr. Waldo Burnett, a young physician of Boston, suggested this and related theories, which since his death have been proved.

Ten years after, these forms were accepted and classified by botanists.

There were many observers and experimenters in the field and about I88I the science of Bacteriology was founded. To Louis Pasteur must be ascribed the honor of laying its corner-stone, for he first endeavored to cultivate bacteria and yeasts and tried to make pure cultures. Upon the foundation thus laid Robert Koch built the germ theory of disease. He cultivated certain germs and introducing them into the bodies of certain animals was able to produce certain diseases. He then suggested the four rules which still 
govern all those who set out on the search for the germ of any particular disease:

First, the germ found in any disease must be found in every case of that disease.

Identifying

Disease

Germs

Second, this germ must be grown artificially outside the diseased body.

Third, this artificial culture must produce the specific disease in the body of a healthy animal when inoculated into it.

Fourth, the same species found in the original case must be found in the case due to inoculation.

The discovery of the bacillus of Tuberculosis, of Asiatic Cholera, and of Typhoid Fever followed in rapid succession. The last fifteen years have been crowded with searching investigations and numerous brilliant discoveries.

The debt of the world to these discoverers is in importance second only to that which it owes to the bacteria, the molds, and the yeasts. Because the microorganisms have been studied so much from the standpoint of disease, both in food substances and man, their beneficent role is often unappreciated.

\section{SUMMARY}

From the preceding pages may be gathered sufficient information to increase the appreciation of the housewife for her many friends among these microscopic plants-bacteria, molds, yeasts-and to put her on her guard against the many that under certain conditions, which she can largely control, will spoil her 
Dust as

Source of Danger

possessions or the few that may bring disease to her family.

In general the harmful bacteria and other forms are brought into her house as dust, which through somebody's ignorance or criminal carelessness, is allowed to scatter itself; dust allowed to collect in dark warm places, to be blown about by wind; dust rising from dried expectorated matter on sidewalks, floors or fabrics, from drainage infected soil, possibly carried to the water or food supplies.

It used to be said that dirt was matter in the wrong place. We see now that dangerous dirt is simply a certain kind of matter in the wrong place. It is indeed, filth, because this dirt is alive it must not be allowed to grow under any conditions which may bring harm to man.

Summary of Special Terms

A summary of a few special terms explained in the text may serve as a review.

Fermentation from a physiological standpcint is the result of growth in organic matter of a living organized ferment.

Alcoholic fermentation is usually brought about by yeasts. A few bacteria and molds are found to be capable of making weak alcoholic solutions.

Fermentation is applied to the process when the products are desirable or agreeable and non-poisonous.

Putrefaction is fermentation carried so far or under such conditions that the products are undesirable, disagreeable, foul smelling and poisonous. 
It is fermentation of substances containing nitrogen - putrid fermentation.

The products of these fermentative changes are gases which give odors; acids-lactic, acetic and butyric; weak alcohol, occasionally, and ptomaines which, when poisonous, are called toxines.

When putrefaction has ended and the disagreeable products have disappeared, the residue is usually harmless and inoffensive. If the processes of decomposition go on in an abundance of oxygen, decay is usually reached without offensive products.

Sterilization is the removal of all life and is effected by steam, dry heat, chemicals, or filtration.

To remove bacteria, air may be filtered through cotton wool and liquids through unglazed clay or similar substances.

An antiseptic retards or prevents growth. A disinfectant kills.

Some substances are antiseptic or disinfectant according to their strength or the conditions under which they act. Sunshine is Nature's free disinfectant; light is commonly an antiseptic, and may be a disinfectant. Dryness, excess of moisture, salt, strong acids, the essential oils, soap, hot water, etc., may be antiseptic with some species and disinfectants with others.

Pasteurization, chiefly applied to milk and cream, is a process for killing certain germs which cannot endure the temperature of $155^{\circ}$ to $165^{\circ} \mathrm{F}$. for twenty 
minutes. This destroys the pathogenic and lactic acid bacteria. The milk is then safe, that is, does not carry disease germs, and will keep longer than ordinary milk, but will in time sour because other germs gain access to it.

Properly Pasteurized milk retains the natural flavor and its digestibility is more nearly normal than that of milk which has been sterilized.

Spores

Because certain species of bacteria form spores which are very resistant to the ordinary methods of sterilization, it is necessary to repeat the process to ensure success. This repeated boiling for three successive days is known as Intermittent Sterilization.

Dust

Infected material which would be harmed by thorough sterilization should be destroyed by fire whenever possible. It should never be allowed to become dry and thereby add its infectious matter to dust.

The experiments outlined in the text should be performed as far as possible. The whole lesson will be far more interesting if observation of them precedes the book study.

The questions should stimulate the application of all principles suggested in the text and, wherever possible, be answered after actual observation of practice based on those principles.

A further knowledge of the whole subject of the micro-organisms included in the science of bacteriology may be gained by reading the small but interesting books named in the bibliography. 


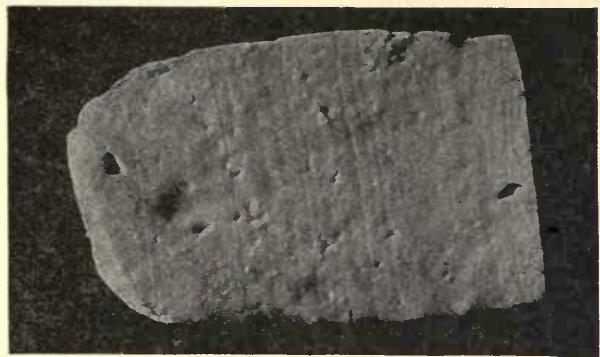

Curd from a good milk. Large, irregular mechanical holes.

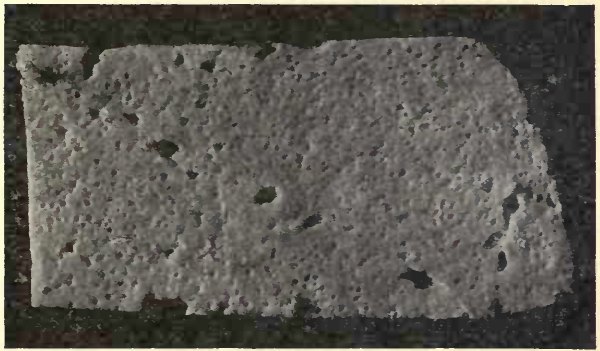

Curd from a tainted milk. Large, irregular mechanical holes; small pinho'es due to gas.

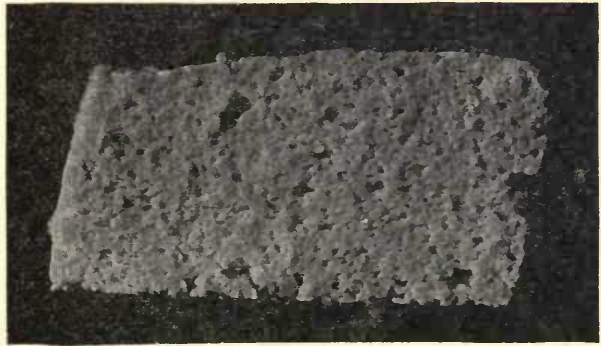

Curd from foul milk. 


\section{DIRECTIONS FOR MAKING THE WISCONSIN CURD TEST}

J. Q. EMery, Dairy and Food Commissioner, Madison, Wis.

I. Sterilize milk containers so as to destroy all bacteria in vessels. This step is very important and can be done by heating cans in boiling water or steam for not less than one-half hour.

2. Place about one pint of milk in covered jar and heat to about 98 degrees $\mathrm{F}$.

3. Add ten drops of standard rennet extract and mix thoroughly with the milk to quickly coagulate.

4. After coagulation, cut curd fine with case-knife to facilitate separation of whey; leave curd in whey one-half hour to an hour; then drain off whey at frequent intervals until curd is well matted.

5. Incubate curd mass at 98 to 102 degrees F. by immersing jar in warm water. Keep jars covered to retain odors.

6. After 6 to 9 hours incubation, open jar and observe odor; examine curds by cutting the same with sharp knife and observe texture as to presence of pinholes or gas holes. Observe odor

7. Very bad milks will betray presence of gas-producing bacteria by the spongy texture of the curd and of flavor.

8. If more than one sample is tested at the same time, dip knife and thermometer in hot water before each time used.

"Normal milk contains practically no organisms but the straight lactic acid bacteria. These germs produce no gas and no bad odors, but purely lactic acid, and the curd formed therefrom is such as is represented in Figure $\mathrm{I}$.

"Milk contaminated by the introduction of dust, dirt, fecal matter, or kept in imperfectly cleaned cans, becomes fouled with gas-producing bacteria that break down the milk sugar and so produce gases and usually undesirable odors.... Therejore milks showing the presence of gas or bad odors in any considerable degree are milks that have been more or less polluted with extraneous organisms or carelessly handled, and as a consequence such milks show a type of curd revealed in Figures 2 and 3."-Dr. H. L. Russell. (For further directions, see Farmers' Bulletin, No. 84.) 


\section{TEST QUESTIONS}

The following questions constitute the "written recitation" which the regular members of the A. S. H. E. answer in writing and send in for the correction and comment of the instructor. They are intended to emphasize and fix in the memory the most important points in the lesson. 


\section{HOUSEHOLD BACTERIOLOGY \\ PART II.}

Read Carefully.-Place your name and address on the first sheet of the test. Use a light grade of paper, write on one side of the sheet only, and leave space between answers. Make all experiments possible and read the lesson book a number of times before attempting to answer the questions. Answer every question fully. Do not be too general in statement. Give details wherever they will show your knowledge.

I. What is the objection to a common comb, drinking cup, etc., to promiscuous kissing on the lips, or to spitting on floors or sidewalks?

2. What is an infectious disease?

3. How does a case of typhoid fever show human carelessness and what should always be done to prevent its spread?

4. Through what avenues do germs attack the body?

5. What are some of the means by which the healthy body resists bacterial attacks?

6. What is a toxine? An antitoxine? A phagocyte?

7. What is an antiseptic? A disinfectant? Mention some of each.

8. What disinfectants should the housewife use most freely?

9. Where do disease germs multiply chiefly?

IO. In what ways should a study of dust affect the housewife's (a) choice of methods in cleaning, (b) 
care of food and clothes, (c) standard in house furnishings, (d) admittance of sunlight and air?

II. Why do dried fruits keep and why do they mold or sour when kept in a damp place?

I2. What other antiseptic and disinfecting methods are used to preserve food?

I3. Do you know any harmful methods of preserving food from the action of micro-organisms?

I4. What objection is there to turning the leaves of books with moistened fingers; wetting envelopes with saliva; putting money and pencils in mouth, etc.?

15. How insure a safe drinking water?

I6. What does healthful dusting of a room require?

17. Explain certain conditions which might prevent bread from rising, (b) why it tastes sour, (c) why slack baked bread may mold quickly, (d) why bread should cool rapidly, (e) why warm milk should not be closely covered.

I8. How may "June flavored" butter be made in January?

19. What especial precautions are necessary to prevent infection with (a) tuberculosis, (b) typhoid fever, (c) pneumonia?

20. What have you learned from Household Bacteriology which can make better conditions for health to yourself and others?

2I. What questions have come to your mind?

Note.-After completing the test, sign your full name. 


\section{SUPPLEMENT TO \\ HOUSEHOLD BACTERIOLOGY}




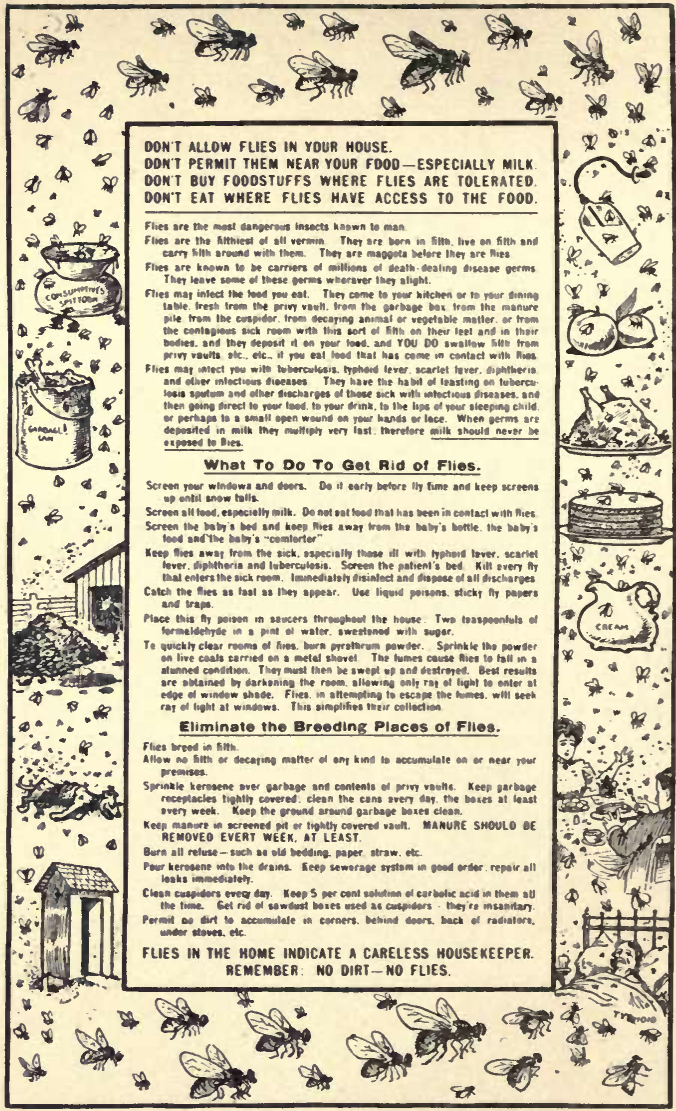




\title{
EXTRACTS FROM THE INSTROCTOR'S NOTE BOOK
}

\author{
By S. Maria Elliott, \\ Simmons College, Boston.
}

Education is not knowledge alone. It is the development of the individual, and this development should make each person a force in the world. No one has a right to keep for himself alone that which another needs. This is pre-eminently true in the line of scientific education. If the material side of life rests upon the principles of natural science, then the knowledge of these principles should, as soon as acquired, be put into practice for our own good. But this alone is selfishness. It gives us power, but power wrongly applied to ignoble uses works havoc. Put any newly acquired knowledge into practical use for the benefit of humanity and the world is improved, while our own lives are enriched. In this way, there is a subtle truth in someone's definition of a scientist : "The man who thinks God's thoughts after Him."

Our school of Home Economics has enrolled among students persons from the Atlantic to the Pacific, from Texas to Canada, and even from far-off Hungary. Some have the schooling of the grammar grades alone, others are in or have passed through colleges and even professional schools. Each has had a different experience from every other and each may learn from his neighbor. 
The young girl in the Tennessee mountains may be able to give of her experience to the college professor, while in between and among all grades a common bond of interest has been welded because of our common studies.

Nor does the enrolled student alone gain knowledge from this company of common workers. The instructors are not barred out from this feast of good things. Through the tests, returned from all quarters and by so many persons of varied attainments, standards of living and rich experiences, the instructors are helped to a broader outlook and if, originally they were able to write facts which might serve as guideposts in daily living, by this time the index finger should assuredly be pointed toward many other helpful paths.

Some one has said that a guide-post is that which tells others to go the way in which you will not walk. This we will not accept, but wherever any guiding finger seems to invite, let us take that path so far at least as it serves our purpose and conditions.

Here are some of the directions in which the students of Bacteriology have walked and others may follow. The following report from Utah may inspire another to do likewise:

"I have tried to put my newly acquired knowledge into practice around the home. For example, I am being more careful of our food products to keep them from dust. I have used a dampened cloth in dusting 
and have tried to impress upon my mind in practical ways the principles of action of these three classes of micro-organisms."

Definitions are said not to define, but who can improve upon this one from Kentucky? An infectious disease is "a disease which is contracted from disease germs which make a specialty of this work," and this is as true to facts, although more difficult to read aloud, "Bacteria are infinitely small, intensely energetic, enormously prolific protoplasmic micro-organisms."

A little knowledge is not always a dangerous thing. One woman says, "I thought when I took up the first lesson paper that there was nothing in it I should ever understand, but now it looks so different." She had seen molds through a magnifying glass, and goes on to say, "At any other time I wouldn't have given it a look or thought."

A guide-post which points decidedly in the direction of success reads:

"Thank you more than I can say for the severity of your criticisms on the answers I sent. I liked it and because of it feel more confidence in the whole course."

From Ohio comes this report: "I did find a doctor in our town who . . . . helped me to see things.

"I had an idea that the contents of the Petri dish might be viewed at once. . . . The doctor said "Yes, under the focus it would be as large as the state of Ohio." 
Perhaps there are other doctors in other towns who would be glad to help the people "to see things."

Some inquiring minds met difficulties, however, in unexpected places. A student who was "as thirsty after information as ever" was discouraged for the time being by the fact that she had borrowed a microscope from a physician who was not recognized by the "regulars." The city bacteriologist who had promised to furnish "microbes" for examination under said microscope refused "because the Board of Health wouldn't like it," if their cultures were used by a physician "who advertised."

Disinfection needs no further explanation to one who has before her the picture which she describes in this way: "Some years ago while traveling in Mexico we had occasion to pass through a yellow fever district. Fearing that the disease germs might contaminate the oranges peddled at the station by the Mexicans and of which we wished to purchase, a member of the party sterilized the fruit on the outside by dipping them in alcohol and burning it off immediately." That yellow fever is transmitted only by the sting of a certain species of mosquito was not then proved. That there may have been other germs on the fruit is not at all unlikely and while the alcohol bath may have been sufficient, the fire was certainly an ingeniously sure method of sterilization.

A practicing physician among the students says that she "wishes every wife, mother and home-maker could 
and would have the advantage of this course of study. Scarcely an hour passes in the day when the practical importance of the lessons is not brought to my mind."

Having gained an insight into the value of the study of chemistry and cleaning, a good Samaritan was anxious to help others and used her influence to have valuable books on such subjects added to the town library.

A wail comes sounding from Georgia: "The housekeeper's life is one round of activity here not only on account of the invisible pests, but those we can see, such as roaches, weevils, etc. These may abound in the north in the eastern part, but we never saw one in Montana." Happy residents of Montana if they have no visible pests, but we have not yet heard that in Montana bacteria are absent.

Mrs. W. finds that strawberries and raspberrries put up uncooked "kept perfectly well so far as (yeast) fermentation was concerned." They molded but only on the surface. When this surface growth was carefully removed, there was no taint present.

From the deck of a houseboat on the Mississippi, in the midst of a cruise of I,200 miles, comes the statement that there bacteria die, "for even the dirt aboard exercises too much to settle down to idleness and mischief." Fresh air and sunshine-Nature's best disinfectants-should certainly be found on such a vacation trip. 
An interested man adds the bit of information which may inspire others to experiment, possibly with success. He says they "have often-in Kansas-tried to preserve figs by canning them but thus far we have failed. Had to preserve them in sugar."

An affirmative answer must certainly be given to the pertinent question: "Do not tooth brushes and wash cloths contain microbes?" They certainly do unless carefully cleaned. The former should occasionally have a bath in borax water. The latter should be well dried daily in the sunshine, if possible, and frequently boiled. There need not and should not be the putrid brush and the sour cloth. The sponge is a very difficult article to keep sweet and clean by common methods. The cloth is certainly much to be preferred from the standpoint of cleanness.

The suggestion is not a bad one that "gloves be worn always while shopping." We may suggest that these gloves might well be washable.

How much healthier our homes would be if we would take the advice of Mrs. W. and "do away with the unnecessary ornaments, merely dust collectors - . . dispose of them and train the eye to simplicity and healthful emptiness." Along the same line is Miss G's decision: "I have been very much tempted of late to give up my rugs and mattings and use carpets, but I feel now that it would be taking a backward step." It would be better, if it were possible, to do away with the matting which unless the 
dust be wiped off from the surface instead of pushed through with the broom, will store much dust underneath.

Miss R. of Illinois has learned that one element in "vital resistance" is to keep one's self in good health, "for then my tonsilitis germs wouldn't have developed." This is her decision after having spent a part of the "Glorious Fourth" in bed in the study of Part II.

One of our students in Michigan has experimented in the sterilization and canning of milk, "using a solution of salt to increase the temperature of the water." She found that by repeating this process three successive days the milk would and did "keep over three years and would have kept indefinitely except for an accident."

An enthusiastic teacher from Canada who "enjoys bacteriology heartily," performed not only the experiments with dust gardens but also numerous others, with most satisfactory results. Her enthusiasm and success may well be passed along for the benefit of others.

One of her best results in growing molds came from a medium of ten per cent prune juice, ten per cent gelatine with eighty per cent water. This was exposed for twenty minutes. In a week there had grown "about twenty mold colonies" and five of bacteria.

Another garden was made like the above, substitut- 
ing jelly for the juice. In this the bacteria flourished better than the molds. One of the gardens which she tried was turned to liquid in a week.

She was fortunate to receive from a bacteriologist a pure culture of b. prodigiosus or the "miracle germ." This she planted in the yolk of a hard-boiled egg and in a week it had transformed the yolk to a red mass mingled with much liquid. This was well covered and kept in darkness. She one day found that the hectograph had become a garden of molds and bacteria. Under the right conditions it might have been liquefied.

That childen can be readily taught by observation is shown by a report from the same teacher. A girl insisted that her hands were clean, but a tablespoon of the water in which she washed her clean hands when introduced into milk proved an efficient aid in its putrefaction. "The cooking class never forgot to wash their hands."

A class of farmers' daughters found many suggestions for their future care of milk products from various experiments in the cultivation in milk of the different species which turn it sour, putrid, bitter, etc.

Such reports as these should stimulate other teachers to interest, to instruct, to educate, by similar experiments, the children under their care. Anything which will raise the standard of personal cleanness or that of food supplies and general house conditions will tend toward health and greater economy. 
And so the tests and personal letters continue to encourage the instructor and open up many a vista of unexpected applications or suggested truths.

The variety of questions show the great need of the study even among those favored with high scholarship as well as among those trained in the thorough but slower school of experience.

When many facts of everyday life, of common observation, are seen to be caused by the growth of omnipresent, invisible plants put into the world as beneficent agents, all life becomes more interesting. Such study should lead away from foolish or ungrounded fear. It should lead to thought and wise action, that the danger spots be prevented or removed; that each do all in his power to protect not only himself but his neighbor.

How strongly it emphasizes the truth from the great poet-philosopher, John Milton:

"Not to know at large

Of things remote from use,

But to know that which

Before us lies in daily life

Is the prime wisdom." 



\section{SAFEGUARDS OF THE BODY AGAINST DISEASE*}

By T. Mitchell Prudden.

Author of "Dust and Its Dangers," "The Story of the Bacteria," etc., etc.

Among the shibboleths of physicians one of the - more recent and perhaps the most widely popular today is the word immunity, relating to infectious or bacterial disease. The subject holds the floor in the learned societies; it crams the medical books and journals; it lures the solitary workers in the laboratories to long and toilsome quests. At last the layman has begun the query as to what it is all about, and how the new lore which filters through the magazines and newspapers out to him may affect his chance for the healthful threescore years and ten which is his birthright, but of which he is too often ruthlessly deprived.

It is really worth while for everybody to know something about immunity to infectious diseases. For the new doctrines and their practical applications in the workaday world are full of promise for the prevention and cure of the infectious maladies, if only the public will bear its part with intelligence and zeal.

The beginning of the story goes back more than a quarter of a century, when the notion still lingered on that disease was a mysterious something apart from

*Reprinted from The Outlook by permission. 
the body machine, which with sinister intent took possession of our interiors and battled for our lives; or was a visitation of Providence about which we might not inquire too curiously. Then suddenly we became aware that the soil, air, and water, the surfaces of plants and of our own bodies were swarming with minute, invisible, living beings, some few of which were of the greatest importance to man because they were capable of inciting serious disorders. By a technical device of the laboratory it was soon found possible to secure these invisible plants from their various sources, to separate them one from another, and to cultivate and study them with as much precision as the farmer grows and gathers his various crops.

Of course at first the few harmful members of this newly exploited group of living things cast a shadow over all the rest. And we shuddered as the pioneer in this new domain of science revealed the thousands and tens of thousands of bacteria which we might be swallowing with our glass of water or with our bunch of grapes. But we were soon reassured, for we were told that we had nothing to fear from the rank and file of our humble, newly discovered commensals; that, on the contrary, they were our friends, without which, indeed, the world of life could not long continue. It was only the few which we must avoid if we would steer clear of tuberculosis, pneumonia, diphtheria, typhoid fever, cholera, and a dozen or so others of the uncanny brood of infectious diseases. 
These disease-producing germs the bacteriologist soon came to know very well as he grew them in the safe purlieus of his laboratories and found out the various ways in which they were able to work havoc in the delicate mechanism of their earth-neighbor, man. Thus the nature of disease became clearer and the problems of its prevention and cure definite and precise.

\section{BARRIERS OF THE BODY.}

The healthy human body is safe-guarded in many effective ways against the entrance and continued life of bacteria and allied organisms. The tough skin affords a most impregnable barrier. The nose and throat and the tubes leading to the lungs are protected with various mechanisms barring the way to many germs which dusty air bears in every breath. The complex chemical processes in our digestive apparatus which convert our food into building material for brain and muscle spell death to the myriads of bacteria with which our uncooked foods are mingled. So. altogether, our life among bacteria, even those of the deadly sort, is usually exposed to little hazard.

But when the best is said, these minute inciters of disease do now and then win their way to the intimate recesses of our bodies, producing serious results. The measure of their ravages is found in the tables of the statisticians, which show that a large proportion of all who die fall victims to these invisible foes, and that, too, at an age when life holds out its brightest promise. 
Now let us see how these germs are able to do such serious damage in the living body. This body is made up of a bony framework, around which various tissues and organs are securely and compactly grouped. Each one of these tissues and organs is composed of tiny structures called cells. The cells are little centers of energy stored up from the food we eat and the air we breathe-little laboratories in which chemical processes of the most subtle character are constantly going on. And the life of the body is simply the sum of the more or less independent but co-ordinated lives of the cells which compose it, all acting in harmony. * * *

All these delicate and exquisitely adjusted elements of the body are able to adapt themselves to many vicissitudes without serious disturbance to that sensitive equilibrium which we name health. We may starve them, surfeit them, overwork them, and poison them in the most abandoned fashion. But they sway back to their respective tasks again when our abuse ceases. Unless we go too far; and then they may struggle on, but only in the halting, perverted way which we call disease.

Now, what happens when into this happy family of cells, each nicely adjusted to the others, and all engaged in their various tasks, living bacteria enter, having escaped the outer safeguards?

But before we try to discover this, let us brush away a few cobwebs. 


\section{NATURE OF DISEASE}

We are so.accustomed to personify disease, to think of it as a visitation of malign forces, and to talk of it in terms which belong in the era of superstition and personal devils, that clear notions of disease as a process, not a thing, are rare indeed.

Disease is a perverted process of the living body cells. Bacteria are not the disease; they are only the inciters of disease; nor do they enter the body with sinister intent. If the chances of the hour bring them to rest among the living body cells, and if the conditions are favorable, they begin to grow, but with just as little purpose for good or evil as if they had lodged upon the surface of a rotten turnip.

Many of the bacteria which enter the body do not grow at all. The soil is not to their liking, the environment is not congenial; they die and are hustled off forthwith by certain lowly organized cells-phagocytes we call them-which are the scavengers of the body, and are ever moving here and there to keep the tissues clear and clean. Many bacteria, on the other hand, find in the living body conditions suitable enough, faute de mieux, for their simple life processes. But they are speedily devoured and digested by the scavenger cells, or are killed by destructive body juices, and so their tragedies end.

But there is another side to the story when the bacteria which are stranded within the tissues are not to be tolerated in a well-organized cell family. Then trouble begins. 
We are likely to think that because bacteria are so small and lowly they cannot do much. . But in fact they do a great deal. Their life processes are extremely complex. They are chemical engines of great potency. Out of the food which they assimilate they manufacture a host of subtle poisons, some of which are stored up in their tiny bodies, some set free into the fluids of their hosts. This, in fact, is the front of their offending: the poisons which they elaborate and set free damage the cells.

Sometimes these poisons interfere with the necessary performances of the cells close about them, or they harm them, but not irretrievably; or they may kill them forthwith. Again, they are carried far and wide throughout the body, and the heart is enfeebled, the brain palsied, or fever dominates the scene.

This is the situation, then, when disease-producing bacteria get in among the living body cells and begin to grow, setting free their powerful poisons. It is cell against cell-the well-bred, highly differentiated cell of the body against the crude, prolific spark of matter way down upon her borderland of life, potent only to eat, to multiply, to shed abroad its poison. But the weapons of both the combatants are poisonous. For we should not permit our sympathetic viewpoint to obscure the fact that the fluids and the digestive juices which our own cells elaborate are poisons for bacteria, quite as much as is their stuff for us. It is the old story of the survival of the fittest here in this 
little hidden arena. A new environment is established both for the body cells and for the bacteria; and what we dramatize as a battle is really only the attempt of each to adapt itself to the new conditions furnished by the other. The one which adapts itself most readily and completely and quickly wins, by survival.

Infectious diseases, then, are those which are induced by the entrance into the body and the multiplication there of disease-inducing micro-organisms. These are most frequently bacteria; but other lowly beings, such as yeasts and minute animals called protozoa, are sometimes to blame. Each of these infectious diseases has its peculiar characteristics by which physicians recognize it. These features are especially dependent upon the nature of the bacteria which induce them: their ways of growing, the nature of the poisons. which they set free, their tenacity of life, etc. But the body cells have their particular vulnerabilities to bacterial poisons, so that in one case it is the nervous system, in another the lungs, in another the digestive apparatus, which especially suffers. Moreover, as one rose is redder than another, or one aromatic plant more pungent than its fellow, so in one case the bacteria which gain access to the body may evolve a more potent poison than in another, and then the disease may be of a more virulent type. So also an individual may at the time of infection be much more susceptible to the ravages of the germ than is usual, and thus the victim of a graver form of disease. 
Now we come to immunity. We have seen that, under the usual conditions, the body may be capable of disposing of bacteria or other microbes which enter it by means of its cells or its fluids, so that the invaders can do no harm. This condition is called hereditary immunity - an immunity which is born with us. There is a good deal of difference in animal species in this respect. For many bacteria which are deadly to some of the lower animals are harmless to man, and vice versa. So also among the lower animals themselves some are susceptible, some not, to the same species of bacteria.

But there is another phase of immunity which we must look at a little more closely, called acquired immunity. It is a very old observation of the doctors, which has become part of the lore of the layman, that there are infectious diseases in which one attack, if recovered from, protects its victim for a longer or shorter period against a subsequent attack. This is true of smallpox, measles, scarlet fever and in less marked degree of typhoid fever, diphtheria and others.

Here is a form of acquired immunity secured through an experience of the disease itself. In fact, recovery from an infectious disease can take place only by the establishment of an immunity which did not previously exist. But this acquired immunity in some instances suffices only for the exigencies of the hour, while in others it persists for some time, precluding fresh infection. 
In order to understand what has happened in the body of a person who has thus acquired immunity through a successfully weathered attack of an infectious disease, it will be necessary for us to look at some very remarkable achievements of the past few years in the prevention and cure of diphtheria. For, though the fact of immunity acquired through disease has been known so long, no one until recently could offer even a plausible conjecture as to the reason for it. Among the earlier of the disease-inducing bacteria to be discovered, some twenty years ago, was the bacillus of diphtheria. This is a little rod-like plant found only in connection with this disease, or in those who have been exposed to it. It is readily cultivated in the laboratory, being very fond of beef tea, in which it is commonly grown.

When a few of these living bacilli from the culture are put beneath the skin of animals, such as rabbits or guinea pigs, a fatal disease is induced, essentially similar to the disease-diphtheria-in man.

In the early days of bacteriology it was believed that, in order to induce artificially the symptoms of an infectious disease, the living germs must be put into the body, and grow there. But it was presently discovered that if you separate all the germs from a culture of the diphtheria bacillus, and introduce the beef tea in which they had grown for some time, into an animal, you can induce the symptoms of the disease just as well as if the germs themselves are put in. 
Thus was revealed the significant fact that bacteria may damage the body quite as much by the poisons which they elaborate as by their direct presence.

Now came the next step in the upbuilding of this remarkable series of discoveries. It was found that if this beef tea in which diphtheria bacilli have grown, and which contains the germ-poison, be introduced into an animal, at first in very minute quantities, which are gradually increased in subsequent doses, the animal grows more and more tolerant of the poison, until at last he sustains with indifference amounts which, if given at first, would have been certainly and speedily fatal.

In other words, it was found that by the use of the poison alone of the diphtheria bacillus in increasing doses, an animal can be rendered artificially immune without having suffered from the disease diphtheria at all.

But now a most incredible thing was discovered. It was found that if the blood be drawn from an animal thus rendered artificially immune, and allowed to clot, the yellowish, watery fluid which separates from the solid part, and which we call blood serum, contains something which, when the serum is introduced into the body of another animal, perfectly protects him, not only from the poison of the diphtheria germ, but from the living germ itself; in other words, ¿enders him, too, immune. 


\section{ANTITOXIN.}

This curious something so potent and so beneficent was called antitoxin, because it acts by neutralizing or abolishing the harmful effects of the toxin-that is, the poison of the diphtheria germ.

No chemist has ever been able to separate antitoxin from the blood serum; no man knows its composition; but there it is, the heart, it seems, of the mystery of immunity.

One might think that we had found here some remarkable cure-all in this antitoxin, and that it would prevent or cure other infectious diseases. But this is not the case. It has no more effect in the prevention or cure of other diseases, such as pneumonia, typhoid fever, etc., than so much water. In other words, its action is specific.

The seeker of light in fields relating to medicine is rarely free from the consciousness of urgency in the solution of his problem. So the moment he found that he could protect the lower animals against the ravages of diphtheria which he had artificially induced, he turned at once to the possibility of human protection and cure. And the situation was indeed urgent. No disease was more dreaded than diphtheria, especially in children; the suffering of the victims was pitiful, the mortality great.

The first experiments were made on small animals, but if the serum were to be used in children larger quantities would be required, so sheep and goats were 
immunized. But these did not furnish enough. So at last the horse was tried, and was found admirably adapted to the purpose. He lends himself readily to the increasing doses of the potent diphtheria poison; he is easily rendered immune, and he furnishes without especial inconvenience a large quantity of blood. In fact, he makes no more fuss about losing blood than did the old people along in the early part of the last century, who were quite accustomed in the springtime, when they felt a bit heavy and had a little headache, to drop into the nearest barber shop to be bled.

The preparation of diphtheria antitoxin has been brought to a high state of perfection. The horses are first very carefully tested so as to be certain that they have no disease. They are well fed and groomed, and suitably exercised. At first a small amount of the diphtheria toxin is injected beneath the skin. After a few days a larger dose is given, and then at intervals larger and larger quantities, until at last the horse is receiving such an amount in a single dose as if given at first would have sufficed to kill not only one but many horses. He has not had diphtheria at all, but he is now poison-proof-immune.

The animal is then bled from the large vein in the neck, the greatest care being taken, by cleansing of the skin, the use of sterilized instruments, etc., that no outside germ shall get into the blood as it flows. This blood is set aside in a cool place, and presently, as the clot forms, the serum separates in considerable quan- 
tity. This is drawn off into flasks and contains the precious life-saving stuff, antitoxin.

Since no one has been able to separate this antitoxic substance from the serum, it is necessary, in order to find out how powerful it is-for its virtue varies with every horse-to have recourse to quite unusual methods. It cannot be weighed as the druggist weighs rhubarb or camphor. But as its value depends upon its powers to neutralize the action of the diphtheria poison in living animals, the test of its strength must be made on these. Guinea pigs are usually employed. It is thus learned how much of the antitoxin to be tested is necessary to save the life of the animal which has received a fatal dose of the diphtheria poison.

The amount necessary for the protection of a human being is larger in such proportion as his weight is greater than that of the guinea pig. The saving power of each specimen of antitoxic horse serum having been thus determined, it is carefully tested to see that no contamination has taken place, then it is divided into the proper doses, each in a small sealed bottle, and sent out upon its mission.

This antitoxin is not effective if given by the mouth, as many drugs are; but it is introduced beneath the skin by a small syringe, and is speedily absorbed into the body fluids.

Now, what has been accomplished by the use of this new and curious form of medicine? The mortality 
from diphtheria, taking the results the world over and in a general way, has been reduced more than 50 per cent, and, under the most favorable conditions, full 75 per cent. I need not dwell upon the significance of this beneficent result in the saving of life and in the relief of suffering.

But there is another way in which diphtheria antitoxin has been of the greatest value; that is, in the prevention of the disease among those who have been exposed to infection in families, schools, and other public institutions. Under these conditions an injection of the antitoxin beneath the skin has been the means of warding off an attack of the disease in groups of persons, some of whom without it must inevitably have

We should be most ungrateful if we failed to recognize the importance of this new relationship which has been established between ourselves and our old and ever-useful friend, the horse. We make him manufacture for us in the department of his interior that protective stuff which we could otherwise secure only by ourselves sustaining an attack of diphtheria, and this, too, with the chances against success.

We are now prepared to inquire how this curious antitoxin acts in the body to produce these truly marvelous effects. Has the body kept secreted all through these years of evolution some special mechanism, or șome chemical potency, by which all of a sudden it can protect itself against so subtle and so special a poison as this roving bacillus? And if so, do we keep 
on hand in our mysterious insides the latent power of protection against all the special forms of diseaseproducing bacteria which wander the earth? How does it fit into physiology? Or can we indeed create new protective powers in the stress of such varied accidents as new infections involve?

We have seen that the diphtheria bacillus produces its deadly effects through a poison which it sets free as it grows in the body. In order to understand how this poison is rendered harmless, we must know how it damages the delicate body cells. So we must go back to the cell for a moment. These cells in the living body sit in their respective places, and as the nutrient fluids pass and bathe them, each of them being a powerful little chemical factory, they seize upon whatever nutrient molecules they require, and out of these build up such new substances as they need in their business, whether this be self-nutrition, or the storage of energy, or the furnishing of special lifestuff for their neighbors. So each cell is armed with this power of forming chemical union with the food.

But suppose something comes along in the body fluids with which the cell can and does form the same sort of chemical union, but which is not a food; on the contrary, damages the cell-that is, is poisonous or toxic for it. The cell suffers, of course-first, by the direct damage, and, second, by the loss of its food-securing capacity. The latter it has used up in uniting with the poison. 
Now, the cell-so runs the theory-finding itself deprived of its food, produces a new and increased amount of this food-seizing substance. In fact, in accordance with a well-known law in pathology, it produces such a surplus of this substance that it is cast off into the body fluid.

But this food-seizing substance, now produced in superabundance and cast off, is still capable of uniting with the poison which is circulating in the body fluids. This it does, and as molecule by molecule the poison forms the new chemical union it is neutralized and so prevented from coming in contact with the cells, where alone it can do harm. This is antitoxic immunity.

Now, if more of this stuff is given off by the cells in the emergency than is necessary to render all the poison harmless, the excess in the body fluid remains there as unused antitoxin. This is the condition of the immuned horse. His cells have produced more antitoxin than is necessary to protect himself, and we draw off some of it in the blood and use it to save the child.

Thus we see that this curious protective process is not an incredible anomaly, but that the body cells have availed themselves in an emergency as protective agencies of those capacities which under normal conditions they use in the assimilation of their food.

This power of the body to protect itself against the poisonous products of bacterial life may be exerted 
in a similar way in the presence of other poisons. Thus certain poisonous vegetable extracts and the venom of snakes may be used to secure artificial immunity in the horse, with the development of antitoxin. In countries where venomous reptiles abound the loss of life from their bites is sometimes very great; for example, in India, where the great cobra slays many victims. An antitoxin for snake poison is now made which is most effective against the bites of the cobra and several other venomous serpents. It is called antivenin. Its efficiency for rattlesnake bites has been claimed, but recent studies have thrown some doubt upon this point.

Of course as soon as this remarkable diphtheria antitoxin was discovered the eager workers in the field of preventive medicine at once concluded that we were at the dawn of a new day. For if we can so effectively control the ravages of diphtheria, why not of the other bacterial diseases? So everybody set to work to discovêr new antitoxic sera-of pneumonia, tuberculosis, plague, typhoid fever, cholera and various forms of blood poisoning, the bacterial excitants of which were already known.

But, unfortunately, these efforts, pursued with the utmost zeal and persistence the world over, have thus far met with very little success. Antitoxic sera for tetanus, or lockjaw, and for some forms of blood poisoning, have seemed to be measurably useful. But, for the most part, the attempts have failed, except in 
the daily newspaper, for which the discovery overnight of a new "serum" seems to furnish an item of perpetual interest.

The reasons for this failure are in part evident to experts in this field, in part are still very obscure, and are too technical to be entered upon here. But the eager and toilsome search goes on with such inspiration as is ever his who deals with these urgent problems of life and death, and at any moment the key to the riddle may lie in our hands.

It would be interesting, did the scope of this article permit, to look at the means by which the body protects itself against infection, not by neutralization of poisons, but by the actual destruction of the poison producers-the bacteria themselves. Suffice it to say that here also, in this bacteria-destroying phase of immunity-germicidal immunity, it is called-the body does not command new forces or mechanisms, but makes use of those which are maintained for its daily service, but which in the emergency it wields to new ends and with exalted energy.

\section{OTHER METHODS OF PROTECTION.}

When it was found that it was not possible at once to secure antitoxic sera for other infectious diseases in the way which had been so successful with diphtheria, the attempt was made to obtain protection in some other way. The leading idea in these researches was to find a method of adapting man to pathogenic germs without exposing him in the process to the 
risks of the disease. Some bacteria seem to produce their harmful effects not so much by the poisons which they set free as by something stored up in the bodies of the germs themselves. But if the living germs are put into the body, they may cause the disease, and the very thing to be guarded against might thus be precipitated.

So the attempt was made to avoid this risk by killing the germs by heat and then injecting these dead organisms beneath the skin of the person to be protected. This method has been practiced on a large scale in some countries with the typhoid fever bacillus and with the bacillus of the plague. While some measure of protection seems to have been secured in this way, the method has not been very generally adopted.

There are two other forms of artificially induced immunity which we must consider briefly, since they belong among the greatest life-saving agencies at our command today. I refer to vaccination for protection against smallpox and the preventive inoculations for rabies or hydrophobia.

\section{VACCINATION}

First, vaccination to prevent smallpox. If the good Dr. Jenner, who more than a hundred years ago did some excellent observing and some clear thinking about what he saw, and found out how to prevent smallpox, could listen to our up-to-date talk about bacteria, microbes, toxins and antitoxins, and various phases of immunity, he would not understand a word 
of it. But, just the same, he led the way to the practical banishment through artificial immunity of one of the greatest and most dreaded scourges of man.

It was known in Jenner's time that those who milked cows having sores upon the udder, due to a local affection called cowpox, often acquired similar sores upon their hands. These soon healed, involving only a slight illness. But such persons had become partially or wholly immune to the more serious disease of man, smallpox.

Jenner studied this subject carefully and came to the conclusion that artificial inoculation with a very small portion of material taken from such cattle might be practiced on a large scale with beneficent results. In spite of much opposition he urged his views, which were gradually accepted, until at last the method has become almost universal in civilized communities.

Large and carefully managed establishments are now devoted to the preparation of the virus, as it is called, by which artificial immunity to smallpox is secured. The slight affection of animals-calves-from which the virus is taken, is called vaccinia, while the disease corresponding to it in man, smallpox, is called variola.

The method now practiced on the large scale is very simple. Healthy calves are carefully cleansed and kept in clean, airy stalls. The belly is shaved and most scrupulously freed from all possible sources of contamination. Into this clean surface, slightly scarified, 
is rubbed some of the virus secured from previous cases. After a few days this surface furnishes a yellowish, watery material which contains the protective stuff. This is gathered and mixed with glycerine, and, after careful tests of its purity, is distributed to physicians in small sealed glass tubes. This virus rubbed on to a scratched surface of the human skin induces a slight sore, sometimes accompanied by a little malaise, and then heals.

By this process the liability to smallpox is very greatly diminished, but the protection is reduced as time passes, so that revaccination is necessary if the fullest protection is to be secured.

It is certain that smallpox is an infectious disease induced by some form of micro-organism.' But the exact character of this is still unknown. Attempts to cultivate it have thus far failed. It appears that the unknown organism suffers diminution in virulence by passing through the body of the relatively insusceptible calf, and in this condition, while incapable of inciting smallpox in man, is still potent to establish immunity.

A good deal of opposition has developed here and there to vaccination even in recent times. This has been based partly upon the fear lest foreign and noxious material should be introduced into the body along with the virus. But if it be carefully prepared, this fear is groundless. While accidents are not impossible, the ill effects which now and then appear are 
usually due to the handling or rubbing of the little wound by dirty persons, against the warning of the physician.

Largely as the result of this form of preventive inoculation, smallpox is no longer to be seriously dreaded. In fact, in the graphic charts which the statisticians make out to show the relative frequency of various diseases, the lines showing smallpox are so short that you can hardly see them; while it is those representing tuberculosis, pneumonia and other diseases of the respiratory system which stretch in most disquieting fashion across the page.

\section{HYDROPHOBIA}

Rabies, or hydrophobia, is one of the most dreaded of human maladies, and one whose victims in former times no medical skill could save. It is an infectious disease, though the micro-organism inducing it is still undiscovered. Hydrophobia is commonly acquired by man through the bites of rabic animals, in this country most frequently the dog. The unknown infectious agent is present in the saliva of affected animals. It travels along the nerve trunks from the site of the bite to the central nervous system, where it especially concentrates itself.

Pasteur, the great master in the solution of knotty problems relating to bacteria and immunity, spent many toilsome and harassing years in the study of the rabic virus and in attempts to devise an effective method of protection. He found at last that, a'though he could not isolate the microbe, he could transmit 
the disease from animal to animal by inoculating into the nervous system of the well animal a tiny portion of nerve tissue from one which had succumbed. The inoculated animals invariably died at a fixed period.

After a long series of studies which we cannot here review, he discovered that if the spinal cord of one of the inoculated animals (rabbits) which had died be dried in a clean place, it gradually lost its virulence, so that whereas at first it invariably killed in seven days, day by day it lost its power, so that after drying for fourteen days it was quite inert. Given thus a virus ranging gradually from the very feeble up to the strongest, he saw the possibility of gradually accustoming the body to the stuff, so that at last it would resist the very strongest.

This was tried on dogs, and it was found that after this gradual adaptation to the virus they became at last wholly indifferent to the bites of mad dogs or the artificial inoculation of the strongest virus. The principle was finally applied to man, with the most remarkable and satisfactory results.

Rabies is peculiar in that a long period usually elapses between the bite of a rabic animal and the development of symptoms. This period, called the incubation period, is in man on the average from thirty to forty days; so that if the preventive treatment be instituted without undue delay, there is usually time for the adaptation of the subject to the artificial virus. This accomplished, the disease does not occur. 
At each laborotary where the treatment for the prevention of rabies is carried on, this material of varying degrees of potency is kept constantly ready, so that as soon as possible after a bite from a supposed rabic animal the treatment may be started. The operation is a simple subcutaneous injection, resulting usually only in a slight or temporary local soreness. The whole affair is completed within two weeks, when all apprehension may be dismissed. No untoward effects follow the treatment.

The mortality from hydrophobia before the day of preventive inoculation was about 16 per cent. Through this treatment it has been reduced to about two-tenths

The methods of securing artificial immunity to infectious diseases, which we have so hastily surveyed, widely different as the details may be, all seem to depend upon the same wonderful power of the body cells to adapt themselves to harmful conditions by the use to new ends of the old physiological capacities.

The task of the investigator centers largely in discovering the ways in which the body cells may be educated to their new responsibilities with safety and despatch.

We seem to be just at the dawn of discovery in this newly opened field, and the outlook is of the highest promise for the relief of suffering and the prolongation of life.

The various preventive means already devised are in the hands of experts and require the greatest care 
on the part of those who make the preparations and skill and judgment in those who advise and administer them. With these things "the man in the street" has nothing to do. But it is for him to see to it that no fad or ism, no false guides, nor ignorance, nor indifference shall hold him from seeking and following wise medical counsel in the face of any of the maladies from which artificial immunity may be secured today. Here ignorance is folly, indifference, crime.

On the other hand, it should not be forgotten that underlying all these protective measures is the living body machine, which each controls for himself. If, through the various phases of unwholesome living so largely in evidence today, the machine is lacking in vigor, then by so much are the chances of recovery lessened when the shadow of disease falls across our path.

Not too much work nor too much play; not too much food and drink, but enough; good air and intelligent cleanliness in houses, assembly places and public conveyances-if these conditions be fulfilled in such way and measure as the hygiene and sanitation of the day demand, we shall go far to establish our birthright to threescore years and ten. And our immunity to infectious disease, whether we brought it into the world with us, or achieve it under the ministrations of the physicians, will most closely confirm the promise of science. 



\section{BIBLIOGRAPHY}

Bacteria, Yeasts, and Molds in the Home, by $\mathrm{H}$ W. Conn. (\$1.00, postage roc)

The Story of Germ Life, by H. W. Conn. (35c., postage 6c.)

Dust and Its Dangers, by T. Mitchell Prudden. (75c., postage 6c)

The Story of the Bacteria, by T. Mitchell Prudden. (75c., postage 6c.)

Drinking Water and Ice Supples, by T. Mitchell Prudden. (75c., postage $6 \mathrm{c}$.)

Our Secret Fri nds and Foes, by Percy Frankland. (\$1.25, postage r 2c.)

Bacteria, by George Newman. ( $\$ 2.00$, postage I8c.)

Bacteria and Their Products, by G. S. Woodhead. (\$1.50, postage $14 \mathrm{c}$.)

Clean Milk, by S. D. Belcher. ( $\$ 1.00$, postage roc.)

Note: The above books may be borrowed by members of the School for the cost of postage.

\section{For Advanced Reading}

A Laboratory Guide in Elementary Bacteriology, by Wm. Dodge Frost. ( $\$ 2.50$.)

Bacteriology and the Public Health, by George Newman. (\$5.00.)

Immunity in Infectious Diseases, by Metchnikoff. (\$5.25.)

Technical Mycology, by Dr. Franz Lafar, 2 vols. (\$8.00.) Micro-örganisms and Fermentation, by Alfred Jörgensen. $(\$ 5.00$. 


\section{Government Bulletins}

Free of the Department of Agriculture, Washington, D. C.

\section{PARMERS' BULLETINS}

No. 29 Souring of Milk and other Changes in Milk Products.

No. 42 Facts about Milk (revised).

No. 43 Servage Disposal on the Farm and the Protection of Drinking Water.

No. 57 Butter Making on the Farm.

No. 63 Care of Milk on the Farm

No. 73 Experiment Station Work - IV, Pure Water.

No. 84 Experiment Station Work - VII. Cured Test for Clean Milk.

No. 92 Experiment Station Work - IX. Pasteurization in Butter Making, etc.

No ro7 Experiment Station Work-XIII, Ropy Milk and Cream.

No. 124 Experiment Station Work - XVII, Soil Inoculation, Distilled Drinking Water.

No. ${ }_{55}$ How Insects Affect Health in Rural Districts.

No. I62 Experiment Station Work - XXI, Purifying Milk by Centrifugal Separation.

No. I66 Cheese Making on the Farm.

No. I75 Home Manufacture and Use of Unfermented Grape Juice.

No. 2 10 Experiment Station Work - XXVII, The Covered Milk Pail.

No. 214 Beneficial Bacteria for Leguminous Crops.

No. 227 Experiment Station Work-XXX, Clean Milk.

No. 233 Experiment Station Work - XXXI, Cider Vinegar. 
No. 240 Inoculation of Legumes.

No. $24 \mathrm{I}$ Butter Making on the Farm.

No. 262 Experiment Station Work-XXXVI, Water for Table Use. Canning by Intermittent Sterilization.

CIRCULARS OF BUREAU OF ANIMAL INDUSTRY

No. I Directions for Pasteurizing Milk.

No. I9 Factory Cheese and How it is Made.

No. 52 A Chemical Examination of Various Tubercle Bacilli.

No. 57 Invisible Microörganisms.

No. 70 Tuberculosis of Cattle.

No. 83 Danger of Infection with Tuberculosis by Different kinds of Exposure.

No. $9 \mathrm{I}$ Bacillus Microphorus and its Economic Importance.

REPRINTS FROM YEAR BOOKS

No. 192 Rabies: Its Cause, Frequency, and Treatment (I900).

No. 221 The Use and Abuse of Food Preservatives (1900).

No. 262 The Contamination of Public Water Supplies, by Algae (1902).

Bacteria and the Nitrogen Problem (1902). 



\section{SUPPLEMENTAL PROGRAM ARRANGED FOR CLASS STUDY ON HOUSEHOLD BACTERIOLOGY}

By S. Maria Elliott, Simmons College, Boston

MEETING I

(Study pages I - I4)

\section{Dust and Dust Gardens}

The growth of a dust garden will impress this whole subject much more vividly than any amount of reading. Each member should plant and watch the growth of at least one garden. One person might prepare and sterilize the nutrient gelatine for the class, distributing in sterilized wide-mouth vials or test tubes about two teaspoonfuls to each. Each member should sterilize the dish or dishes, melt the gelatine by placing the tube in cold water and then heating it, pour into the Petri dish, cover, cool, and plant.

(If not to be had locally, a dozen Petri dishes may be obtained through the School for $\$ \mathbf{I} .90$, a half a dozen for $\$ \mathrm{r} . \infty \circ$, not including express charges. Money will be refunded for those returned.)

Arrange as varied conditions for experiment as possible. The following list is only suggestive of interesting sources and methods of treatment:

(a) After sweeping a carpeted room with a dry broom, expose five minutes, keep at room temperature, but not in direct sunlight.

(b) Same as above but kept in a refrigerator.

(c) Same as " $a$ " but shut up in a box.

(d) Dig out from some corner of stairway or room the dirt which was overlooked in cleaning. Pulverize this and scatter a little over the jelly. Keep in any condition desired:

(e) Let a fly walk over the media. 
(f) Touch the fingers to the jelly after handling dusty books.

(g) Touch the jelly with pieces of money or with a bill.

(h) Take any one of the planted plates. Lay over one-half of the jelly a thick piece of black paper or cloth. Put the dish in direct sunlight.

(i) Scrape a bit of the deposit from the teeth and touch it to several places on the jelly.

(j) Rub a few drops of boiled water in the palm of the hand and $\mathrm{mix}$ it with the liquefied media.

(k) Take one of the dishes to a public gathering and open it for five minutes or more when the audience has been seated for a short time.

Require that each experimenter keep a daily record of every change, however minute. At the next meeting let these experiments be reported, the gardens shown, and as many conclusions drawn as may be feasible, leaving their truth or falsity to be proved by further study.

References: Dust and Its Dangers, by T. M. Prudden. Chapters I, II, III, IV. (75c., postage 6c.) Our Secret Friends and Foes, by Percy F. Frankland. Chapters I-III. (\$1.25, postage I2c.)

Character of Bacteria

If possible, get some physician to show bacteria under a microscope.

(a) Take some from the dust gardens already planted.

(b) Take a drop of water from a vase of flowers which has stood unchanged for a week.

Put a wisp of hay in warm water, let it stand for twenty-four hours in a warm place, then examine with the microscope a drop of the brownish infusion.

Make any experiments possible from "Bacteria, Yeasts, and Molds,": by H. W. Conn, pages $269-285$. 
Porhaps the physician may be able to show some pathogenic germs.

References: The Story of Germ Life, by H. IV. Conn. Chapter I. (35c., postage 6c.)

Bacteria, Yeasts, and Molds, by H. W. Conn. Chapters VIII, IX. (\$r.०o, postage roc.)

The Story of the Bacteria, by T. M. Prudden Chapters I, II, III, and IV. (75c., postage 6c.)

\section{MEETING III}

(Study pages $33-46$ )

\section{Molds and Yeasts}

(a) Show a sample of moldy bread, cheese, shoe, mildew from clothes.

(b) Generate carbon dioxide as shown on page 43.

(c) Examine both yeasts and molds under microscope or hand magnifying glass.

(d) Make a small portion of "milk emptins" as described on page 6. Note changes which occur during one week.

(e) Mix some bread dough. Put a part in the ice-chest, keep an equal part at about $70^{\circ} \mathrm{F}$. and a third at a much higher temperature, $100^{\circ} \mathrm{F}$. or over. Compare results at the end of six. twelve, and twenty hours.

(f) Pour boiling water on a small bit of yeast cake and use this solution for mixing another portion of dough which is to be kept at about $70^{\circ} \mathrm{F}$.

References: Bacteria, Yeasts, and Molds, by H W. Conn. Chapter II, pages I2-24, and Chapters III, IV, V, and VI. ( $\$ 1.00$, postage roc.)

(Select a composite set of answers to Test Questions on Part I and sen 1 them to the School for correction. Report on the supplemental work done and the results of the experiments.) 


\section{MEETING IV}

(Study pages 49-62)

\section{Work of Bacteria}

Fermentation and putrefaction.

References: The Story of Germ Life, by H. W. Conn. Chapters II III, IV. (35c., postage 6c.)

Bacteria, Yeasts, and Molds, by H. W. Conn. Chapters IX-XIII. (\$I.00, postage Ioc) Our Secret Friends and Foes, by Percy F. Frankland. Chapters IV, V. (\$r.25, postage I 2c.) See also U. S. Government Bulletins.

\section{MEETING V}

(Study pages $63-96$.)

\section{Harmful Dust Plants}

(a) Perform the experiments outlined on pages $64-66$.

(b) Boil a pint of milk I 5 minutes. Pour into bottle which has been boiled in water the same time. Close with cork which has also been boiled.

Pasteurize an equal portion (bottle and cork as above). Keep this at about $\mathrm{I}_{55^{\circ}} \mathrm{F}$. for $\mathrm{I}_{5}$ minutes. Keep both under same conditions. Test each day with blue litmus paper. Note first trace of acid. Test by smell and note first signs of coagulation. Compare results in time. When opening, expose as little as possible to dust. Do not lay cork down or touch lower part with fingers. If cork is handled or exposed to more dust, boil again. While cork is out, lay a clean wet cloth over mouth of bottle.

References: Dust and Its Dangers, by T. M. Prudden. Chapters VI, VII, VIII. (75c., postage 6c.) The Story of Germ Life, by H. W. Conn. Chapters $\mathrm{V}$, VI. (35c., postage $6 \mathrm{c}$.) 
Bacteria, Yeasts, and Molds, by H. W. Conn. Chapters XIV, XV. (\$r. oo, postage roc.)

Our Secret Friends and Foes, by Percy F. Frankland, Chapter VI. (\$1.25, postage r 2c.) The Story of the Bacteria, by T. M. Prudden. Chapters V-XIII. (75c., postage 6c.)

\section{MEETING VI}

(Study pages 96-Ir6)

\section{Household Applications}

(a) Make out a list on paper of the most common and most harmful dust gardens occurring in the household the dishcloth, refrigerator, waste-pipe, damp floormop, or any cloths put away in dark closets, uncleaned bread boxes, etc.

(b) Expose small portions of bread, cheese, sauces, meat, milk to dusty air. Keep in warm, dark places and note time, character, appearance of changes.

(c) Consider the care of hands, teeth, all parts of the body; house, sidewalks, backyard, garbage barrels, etc., from bacteriological standpoint.

References: Dust and. Its Dangers, by T. M. Prudden. Chapters V, IX, XI, XII. (75c., postage 6c.) Bacteria, Yeasts, and Molds, by H. W. Conn. Chapter II, pages 24-3I; Chapters VII, XIV. (\$1.00, postage roc.)

Water and Ice, by T. M. Prudden. (75c., postage $6 \mathrm{c}$.)

(Select answers to Test Questions on Part II. Report on supplemental work and experiments.) 


\section{THE BACTERIA SCARE*}

\section{By Mary Hinman Able}

There is a rare form of insanity known to physicians in which the patient is forever washing his hands and fancying that he is polluted by every contact. A few years ago when we were at the beginning of our fight against tuberculosis, typhoid fever and other diseases that may be carried in various forms of filth, it seemed that a mild epidemic of this form of insanity would be a blessing to any community, as it would insure the clean hands which must be insisted on if we are to have clean food. However, when one sees the wholesale and often unwarranted application of a little knowledge of bacteria to every phase of life one is thankful for all the existing sanity and desirous of its extension. For in the wake of every reform is found the trail of the extremist. The Journal of the American Medical Association calls attention in a late issue to certain statements in a book entitled Good Health and How We Won It, by Mr. Upton Sinclair and Mr. Michael Williams. It seems that the writers recovered their health by decreasing the amount of their food and omitting meat entirely. We do not hear as a reason that these gentlemen felt that they were approaching middle life when just this change in the diet has frequently been recommended by physicians, though for reasons unconnected with bacteria; they say they have abandoned eating of meat because of the great numbers of bacteria that it contains, there being, it is slaimed, hundreds of millions of bacteria in different cuts of beef steak and several varieties of sausage.

* From the Journal of Home Economice. 
It is said that every form of error may be traced to faulty logic; here the trouble seems to be that the premises are false. "Meat contains many bacteria. All bacteria are harmful, therefore, etc." The investigators do not state the kind of bacteria nor the way they came to be present in the meat, and evidently they believe that meat in and of itself is naturally and normally laden with these minute forms of life. As a matter of fact though results of a different character have been reported not infrequently, carefully made and carefully controlled laboratory work with all precautions taken has shown that the raw flesh of healthy animals is stirile, and only in certain animal diseases is bacterial life present in the tissues.

All living things, both plants and animals, are subject to bacterial diseases, but if bacteria are found on raw or cooked meat from healthy animals it is safe to say that they were lodged there by passing air currents just as they are lodged on any other food thus exposed. Rightly interpreted then, the laboratory experiments indicate that all foods should be protected from accidental contamination by bacteria, as harmful species may be present among them, not that meat should be excluded from the diet because bacteria happen to be found on it.

A very few bacteria, not more than 50 or 60 species, are known to be harmful, many are known to serve a useful function and it is thought that some varieties may even prove to be necessary to the digestive processes. The intestinal tract of man swarms with bacte:a, and the experimenter has never been able to free from bacteria the digestive tract of an animal that has once lived under normal conditions. Of the foods we eat there are absolutely none free from bacteria, if we except cooked food 
fresh from the fire. The purest milk obtainable for the table contains thousands of bacteria to the cubic centimeter, while commercial milk may have many millions. Buttermilk and other forms of acid milk also contain correspondingly large numbers. Many hundreds of these harmless bacteria are known and named, while the harmful or pathogenic bacteria number only a few score. It is these few malevolent microbes that must be avoided, and hence all tho precautions we have adopted as to cleanliness in hospital, market, dairy and kitchen. But if life is to be worth living we must learn where these objectionable varieties come from in order to concentrate at the proper place our use of that eternal vigilance which is the price of health.

Here are a few suggestions. Human contact with food is probably the greatest source of danger. If a piece of dry bread fall on the floor of a clean private house the bacteriologist tells us it might be picked up and eaten with impunity. Not so if this bread were to be dropped on the floor of a trolley car, especially in the old days when expectoration was common. The driver's hand which grasps the top of the milk bottle which he delivers may leave bacteria there and the bottle should be washed before the milk is poured out. The diminishing of the number of bacteria in our food by the practice of cleanly habits (and no one of these habits is more important than the thornugh washing of the hands before handling and preparing food and before meals) is recommended by all hygienists; but there should be no morbid fear of the consumption of foods that have been the dependence of the race since the dawn of civilization and before, simply because we do not ordinarily eliminate from them every trace of bacterial life. 


\section{INDEX}

Acetic acid, sugar changed to, 6 I

Acid, butyric, 62

Acids as preservatives, 72

Acquired immunity, 94, 134

Agar for dust gardens, Io

Alcoholic fermentation, I I 4

Alexines, 93

Animalcules, 109

Antiseptics, 65

Antitoxin, 94, 137-1 44

diphtheria, 95, 138

Artificial immunity, 94, 136

Bucteria, 16-32

as scavengers, 48

classed as plants, II 2

definition of, 16

disease producing, 75

effect of cold on, 90

excretions of, $\mathrm{I} 8$

experiments with, 64

food of, 20

forms of, I 7

growth of, 22

harmful, 63

in cheese making, 60

in coarse meals, 45

in "eyes" of potato, 45

in ice, 85

in milk, 14

in school rooms, 107

liquefying, 74

method of study of, 1 r 2 natural home of, 30

nitrifying, 5 I

on dust particles, 97

secretions of, 3 I

size of, 23

structure of, I 7

useful, 47

with flagella, 27

work of, 47,54

Bacteriology, history of, rog-

I 13

lessons for children, I 24

Barriers of the body, I 29

Bed-making, ro2

Blood poisoning, $9 \mathrm{I}$

Body, barriers of the, 129

Boiling clothes, necessity for, 30

Bread, baking, 45 leavened, 6

Breeding ground for germs, 77

Brushing clothing, ro6

Burn infected material, I 6

Burning sweepings, $\mathrm{IO}_{4}$

Butter bacteria, 55

bad flavors in, $5^{8}$

making, 55

Butyric acid, 62

Canned goods, 70

Carelessness, criminal, 83

Care of discharges in disease, 79 of plumbing, ro6 of refrigerator, 29 
Cause of lockjaw, 80

Cheese, 59 molds in ripening, 59

Cider vinegar, 60

Clean eggs, 73

Clean milk, I 4

Cleaning school rooms, 107

Cleanness, sanitary, 108

Clothing, brushing, 106

Colonies of bacteria, I 2 of dust plants, I0, 15,16

Color of mold spores, 38

Common methods of preserving food, 68

Communicable diseases, 75

Compound microscope, I 10

Compressed yeast, 43

Contamination, sewage, 82

Covering food, IO4

Criminal carelessness, 83

Crops, rotation of, 53

Cultures, solid, I I I

Deadly dish-cloths, Io6

Deaths from lockjaw, 80

Decay, II 5

Diphtheria antitoxin, 95 bacillus, $\mathrm{r}_{35}$

Disinfectants, 65 nature's, 98

Disinfectant, sunshine as a, 25

Disinfect soiled articles, 79

Disease, care of discharges in,

79

from molds, 36

germs, 75-86

germs, effect of light on, 83 germs, identifying, I 13

germs, origin of, 77

nature of, I 3 I

producing bacteria, ${ }^{2} 32$

Diseases communicable, 75

infections, I 33

specific germs of, 76

Drying food, 70

Dust, I-7

movements of, 4

ordinary, 5,13

particles, bacteria on, 97

plants, 15

plants in refrigerator 28

plants, life work of, 63

sources of danger, I I 4

Dusters, washing, 104 、

Dust-garden out of doors, 73 plot, the, 7

Dust-gardens, $7^{-14}$

photographs of, 1, 1 2, 99,

103,105

planted after sweeping, 98 soil for, 13

Dusting, rules for, 104

time for, 100

Dust-proof room, 2

Effect of antitoxin on the body, I 40

of cold on bacteria, 90 of gastric juices on bacteria, 87

of light on disease germs, $8_{3}$ of poisoning, 92

of sunlight on disease germs, 26 
Eggs, clean, 73

Epidemics of typhoid, $8 \mathrm{r}$

Essential oils as preservatives, 72

Excretions of bacteria, 18

Experiences of students, 119-

124

Experiments in hospitals, 100 with bacteria, 64

with dust, 7

with yeasts, 42

Extracts from the Instructor's Note Book, I I 7-I 25

Favorable conditions for germs, 76

Fermentation, I 4 early theory of, 1 Io processes, 53 products of, I 15

Film-forming bacteria, 22

Filtered water, 85

Filters, porcelain, 84

Fission reproduction, $2 \mathrm{I}$

Flagella, bacteria with, 27

Food, covering, 104

of bacteria, 20

Forms of bacteria, I 7

Formation of pus, 90

Fungi, bacteria classed as, 23

Gas produced by yeast, 44 Gastric juices, effect on bacteria, 87

Germ, definition of, 16

Germs, breeding ground for, 77 disease, 75-86 pathogenic, 66

resistance of body to, 86

Growth of bacteria, 22

of dust-gardens, 1 I

of mold, 33

of yeast, 40

Harmful bacteria, 63

preservatives, 69

Health, definition of, 88

History of bacteriology, 109I 3

Hydrophobia, 148

Ice, 85

Identifying disease germs, I I 3

Imnlunity, 92, 134

artificial, 136

natural, 9.3

Importance of bacteriology, 32

Infected material, burning, I 6

Infection by oysters, 82 method of, 78

sources of, 86

Infectious diseases, 133

Ingredients of dust, 4

Inoculating the soil with bacteria, $5^{2}$

Intermittent sterilization, 65 , I 6

June butter, 55

flavor bacterium, 56

Koch's theory, I I I

Laboratory study of bacteria, $3 \mathrm{I}$

Lactic acid, production of, $\mathbf{I} 4$ 
Leavened bread, 6

Leucocytes, 88

Life, spontaneous generation of, 109

work of dust plants, 63

Liquefying bacteria, 74

Lockjaw, cause of, 80

Making antitoxin, 95

Meadow tea, I ro

Metchnikoff's theory, 93

Meteoric dust, 3

Method of infection, 78

of study of bacteria, I I 2

Microbe, definition of, 16

Micro-organisms, 16

Microscope, compound, I 10

Mildew, 6, 37

Milk, bacteria in, I4

clean, I 4

Pasteurized, 67

souring of, I 3

Mold, reproduction of, 33

spores, 35

Molds, 6, 33, 39, 59

in ripening cheese, 59

work of, 36

Moldy houses, $3 \mathrm{~s}$

Movement of bacteria, 26

Movements of dust, 4

Mustiness, 37

Natural home of bacteria, 30 immunity, 93

Nature of disease, I 3 I

Nature's disinfectants, 96

Necessity of dust, 2
Newman's theory, 93

Nitrifying bacteria, 5 I

Nitrogen traps, 52

Nutrient media for dust-gar. dens, 13

Opposition to vaccination, $\mathbf{I} 47$

Ordinary dust, 5, 13

Origin of disease germs, 77

Oxygen, relations of bacteria to, 24

Oysters, infection by, 82

Pasteur's theory, 95 work of, I I I, I 48

Pasteurization, 66, II 5

Pasteurized milk, 67

Pathogenic germs, 66

Personal responsibility for

sanitation, ro8

Petri dish, 7

Phagocytes, 88

Photograph of dust-gardens,

I, I 2, 99, 103, 10 5

Planting dust-gardens, Io

Plants, bacteria classed as, I 2

Plumbing, care of, 106

Poisoning, blood, 9I

effects of, $9^{2}$

Polluting water, 83

Porcelain filters, 84

Precautions to avoid germ in.

fection, 79

Preparing soil for dust-gar-

dens, 9

Preservatives, 72

Preserving food, 68 
Prevalence of dust, I

Production of lactic acid, I 4

Products of fermentation, I I 5

of yeast growth, 40

Protoplasin, I 7

Pus, formation of, 90

Putrefaction, I 2

Rabies, ${ }^{4} 8$

Refrigerator, care of, 29

Relations of bacteria to oxygen, 24

Removing dust, I04

Reproduction of bacteria, 20 of mold, 33

Resistance of body to germs, 36

of spores, 28

Ripening cheese, $5^{8}$

Roquefort cheese, 59

Rotation of crops, 53

Rules for dusting, 104

Safeguards of the body against disease, $127-15$ I

Salt as a preservative, 72

Sanitary cleanness, ro8

Sanitation, 96-108

personal responsibility for, ro8

Scavengers, bacteria as, 48

School rooms, cleaning, 107

Secretions of bacteria, $3 \mathrm{I}$

Settling of bacteria and molds, $9^{8}$

Sewage contamination, 82 Shape of bacteria, 17
Size of bacteria, 23 of yeast, 39

Soil for dust-gardens, $8, r_{3}$

Soiled articles, disinfect, 79

Solid cultures, I I I

Source of dust, 3

Sources of infection; 86

Souring of milk, I 3

Specific germs of diseases, 76

Spoiling, 7 I

Spontaneous generation of life, 109

Spores, I 6

mold, 35

of bacteria, 27

of yeast, 39

resistance of, 28

Starters, 57

Sterilization, I 5 intermittent, 65, I 6

Structure of bacteria, $\mathrm{I} 7$ of yeast, 39

Sugar as a preservative, 70 changed to acetic acid, $6 \mathrm{I}$

Summary, I 3 of terms, I 44

Sunlight, effect on disease germs, 26

Sunshine as a disinfectant, 25

Sweeping, 97 dust-gardens planted after, $9^{8}$.

Sweepings, burning, I०4

Symptoms of poisoning, 92

Temperature for yeast growth, 4 I 
Terms, summary of, II 4

Tetanus, 80

Theories of vital resistance, 88

Time for dusting, 100

Toxins, 93

Typhoid, epidemic of, $8 \mathrm{I}$ infection by milk, $8 \mathrm{r}$

Useful bacteria, 47

Vaccination, 94, r45 opposition to, 147

Vinegar, 60

Vital resistance, theories of, 87

Wandering cells, 88
Washing dusters, ro 4 Waste of nitrogen, 5 I Water, filtered, 85 polluting of, 83

Work of bacteria, 47-54 of leucocytes, 88 of molds, 36 of Pasteur, III

Yeast, 39

compressed, 44 generating carbon dioxide, 43

Yeasts, effect of cold on, 42 experiments with, 42

Zooglea, 22 


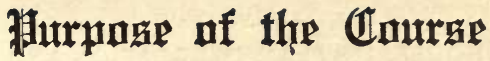

$\mathrm{O}$ make housekeeping an inspiring profession, instead
of deadening drudgery.

TO make the daily work in the home of fascinating interest instead of monotonous labor.

TO make housekeeping easier and simpler by utilizing modern science in the home.

TO make the household money go further, that the higher things of life may be included.

TO preserve and increase health, and thereby promote happiness and prosperity.

TO develop the children - mentally, morally and physically - to their finest possibilities.

TO effect the conservation and improvement of the American home.

$T^{O}$ raise ideals of American home-making.

-American School of Home Economics.

NOTE-The 100-page booklet, "The Profession of Home-Making," gives details of the home-study domestic science courses. It's free. Bulletins "The Up-to-Date Home," "Free Hand Oooking" and "Food Values," 100 each. Address-A. S. H. E., 606 W. 69th St., Ohicago, Ill. 


\section{THE LIBRARY OF}

PARTIAL BYNOPSIS

Vol, 1. THE HOUSE: ITS PLAN, DECORATION AND CARE, by Prof. Isabel Brevier, University of Illinois.

Treats of the development of the modern home and the American house, the planning of convenient houses, construction, floors; the problems of decoration and furnishing; gives suggestions for changes, repairs, household conveniences, "The Cost of Building," etc.

Vol. II. HOUSEHOLD BACTERIOLOGY, by S. Maria Elliott, Simmons College, Boston.

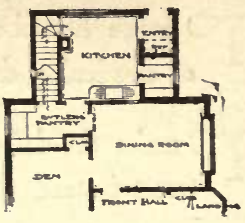

An interesting account of the microscopic forms of life and their relation for good and evil to the household; what dust is and how to make "dust gardens"; disease germs and how to avoid them; the protecting agencies of the body and how to keep them active; sanitation, etc.

Vol. III. HOUSEHOLD HYGIENE, by S. Maria Elliott, Simmons College.

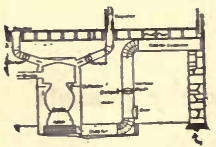

The healthful home; the best situation for the house; importance of the cellar; all about drainage heating, lighting, disposal of wastes, plumbing tests, the water supply; practical suggestions for sanitary furnishings and care; hygenic housekeeping, etc.

Vol. IV. CHEMISTRY OF THE HOUSEHOLD, by Margaret E. Dodd, S. B., Mass. Institute of Technology.|

"A Day's Chemistry"-a fascinating account of the unseen forces in the common things met in a day's workwater, air, fire, fuel; chemistry of food, of digestion, of cookery, of baking powder, of cleaning, of laundry, of stains, of lighting; home tests; home-made baking powder, soap, etc., etc.

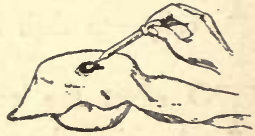

Vol. V. PRINCIPLES OF COOKERY, by Anna Barrows, Columbia University and Chautauqua School of Cookery.

"A key to the cook books"-analyzing and explaining the principles on which success rests; all approved methods of cookery explained, particular attention being paid to economy of time and materials; full consideration of menus, making a fireless cook-stove, "Directions for Waitresses," etc.

Vol. VI. FOOD AND DIETETICS, by Prof. Alice P. Norton, University of Chicago.

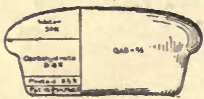

Tells of the composition, nutritive value and digestibility of foods; how the body makes use of food; food economy; the balanced ration; healthful diet for the sedentary, the aged, the children, and so on; food adulterations, etc. 


\section{HOME ECONOMICS}

Vol.VII. HOUSEHOLD MANAGEMENT, by Prof. Bertha M. Terrill of Hartford School of Pedagogy.

Full treatise on economy in spending; the proper division of income; systems of household accounting; system in housework; the servant problem; help by the hour; buying supplies and furnishings; how to market economically; cuts of meat; season of vegetables; experiences of students; "Co-operative Housekeeping," etc.

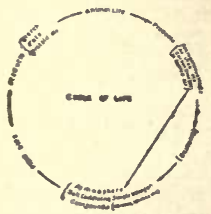
Vol. VIII. PERSONAL HYGIENE, by M. LeBos- quet, S. B., Director of A. S. H. E.

The wonderful human machine; running the machine; care of the machine-sufficient physiology given to show the reasons for the directions for maintaining health; emphasis placed on do rather than don' $t$; articles on "Ethics of Health," "Use and Abuse of Drugs," etc.

Vol. IX. HOME CARE OF THE SICK, by Amy E. Pope, Presbyterian Hospital, New York City.

Includes the essentials of trained nursing; specific directions for handling and caring for the patient; nursing in contagious diseases: obstetrics; food for the sick; emergencies; poisons and their antidotes; bandaging; articles on communicable diseases, etc.

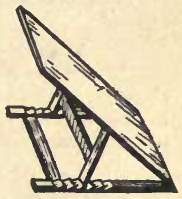

Vol. X. TEXTILES AND CLOTHING, by Kate $H$. Watson, formerly Lewis Institute and University of Chicago.

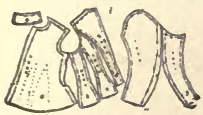

Fully illustrated description of primitive and modern methods of manufacture; textile fibres and fabrics; plain and ornamental stitches and their applications; machine sewing; cutting and fitting of waists and skirts, color and ornament; children's clothes; repairs, etc.

\section{Vol. XI. STUDY OF CHILD LIFE, by Marion Foster Washburne, editor "Mothers Magazine."}

Thoroughly sensible and practical direction for the treatment of children; faults and their remedies; character building; home occupations; play; associates; studies and accomplishments; religious training; the sex question, answers to questions, etc.

Vol. XII. CARE OF CHILDREN, by Dr, A. C. Cotton, Prof. Children's Diseases, Rush Medical College, University of Chicago.

The care of the baby before birth and of the new baby; healthful clothing; development and growth of the child; authoritative and specific directions for feeding; food disorders; food for older children; treatment of children's aliments, hygiene of the child through pubescence, etc

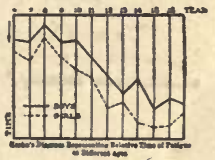




\section{COMMENDATION ON THE COURSE IN BOOK FORM:}

\section{THE OUTLOOK}

"It is true that the management of the home and the care of the family may now rightly be called both a business and a profession. Looking at the subject in this light, the volumes of this library may be regarded as the tools and formulae for carrying on the work in a systematized and intelligent manner. ${ }^{*}{ }^{*} *$ A wise discrimination has been exercised in the choice of the authors of the lessons, for these writers are recognized authorities and special students in the various fields with which they deal. In all cases, simplicity of statement and clarity ${ }^{*} *^{*}$ brevity without sacrificing completeness, are qualities carefully sought for."

\section{THE INDEPENDENT}

"Each of these series of lessons is written by an expert-one possessing special knowledge on the subject concerning which he or she writes. ${ }^{*}{ }^{*}{ }^{*}$ The volumes are handy and are well illustrated and contain an immense amount of information. Things that it must take an old housekeeper years of experience to learn, the young housekeeper may have here under her hand at the very beginning of her regime."

\section{GOOD HOUSEKEEPING}

"Practically all the material needed by the home-maker who wants to know about the inside and the outside of her house and the health of those within it is to be found in these twelve volumes. The books are easy to read and scientific without being technical."

\section{BOSTON COOKING SCHOOL MAGAZINE}

"This is the first time that an attempt has been made to gather together the whole broad subject of home economics into one correlated series of volumes. They give an epitome of the kind and scope of instructions given on this subject at the present time."

\section{THE CRAFTSMAN}

"Altogether the course seems to be widely useful in its scope, and very straightforward and practical in its work."

\section{BOSTON TRANSCRIPT}

"These well printed and liberally illustrated volumes present a course of reading and study that shows to what extent the profession of home-making and art of living make for self-culture and the practical ends of our daily existence."

\section{CHICAGO TRIBUNE}

"Each volume is prepared by practical instructors, speaking with authority in their particular lines. They are well illustrated and are calculated to diffuse a great body of necessary information to those interested in household advancement."

\section{IOWA STATE BOARD OF HEALTH BULLETIN}

"We most heartily commend these courses to all persons interested in healthy homes and the development of a vigorous people-mentally, physically and, as a consequence, morally." 


\section{SCHOOLS USING OUR TEXTBOOKS}

\section{Colleges}

University of Chicago

University of Illinois

University of Wisconsin

University of Missouri

Simmons College, Boston

Columbia University

Millikin University

Connecticut Agricultural College

North Dakota Agricultural College

South Dakota Agricultural College

Colorado Agricultural College
Rhode Island Agricultural College

Montans Agricultural College

Michigan State Agricultural College

Kansas State Agricultural College

New Mexico Agricultural College

Utah Agricultural College

Brigham Young University

Drake University

Adelphi College

Illinois Woman's College

College of Industrial Arts, Texas

\section{Normal Schools and Academies}

Mechanics' Institute, Rochester, N. Y. Stout Institute, Menominee, Wis. Georgia Normal \& Industrial College Iowa State Normal, Cedar Falls Wisconsin State Normal, Superior Michigan State Normal, Mt. Pleasant Kalamazoo Manual Training, Mich. Normal \& Industrial College, N. C. Illinois State Normal School, Macomb Mass. State Normal, North Adams Thomas Normal School, Detroit Throp Polytechnic Inst., Cal. California Polytechnic School
Garland Training School, Boston Fort Edward Collegiate Institute Hampton Normal Institute Chicago Normal Extension Lasell Seminary Webber Academy, Ogden, Utah Snow Academy, Ephraim, Utah Pennington Seminary, New Jersey Mount de Chantal, West Va. Ferry Hall, Lake Forest, IIl. Miss Capen's School, Northampton Miss May's School, Boston, Mass.

\section{High Schools}

Chicago High Schools

Francis W. Parker School, Chicago

Los Angeles High Schools

McKinley High, St. Louis

Providence Technical High School

Springfield, Mass., Tech. High School

Fitchburg, Mass., High School

Greenville, Ohio, High School
Bridgeport, Conn., High School Burlington, Iowa, High School Rockford, Ill., High School Sycamore, Ill., High School Chippewa Falls, Wis., High School. Deerfield Township High School, Ill. Princeton Township High School, Ill.

\section{Bureau of Education, Department of the Philippines}

\section{Sets "Library of Home Economics"}

The "Library of Home Economics" has been purchased as a reference work by nearly all prominent schools offering courses in home economics or related subjects, by most public libraries of the first class, and by over 4,000 progressive bome-makers. It may be seen at many book dealers. 


\section{ANNOUNCEMENT}

\section{"LESSONS IN COOKING, THROUGH THE PREP. ARATION OF MEALS."}

HIS new correspondence course in cookery has been prepared to meet the needs of home-makers who have had little or no systematic training in modern methods of cooking but who desire to provide for their families simple, yet appetizing and wholesome meals, with the last expenditure of time, effort and money.

The ordinary cook book, with its numerous and complicated recipes, is of little help to the beginner. It does not answer the oft occurring question, "What shall I provide for today, tomorrow, for next week"? It gives no hint of wholesome food combinations or balanced diet.

The problem of home cooking is not only how to cook various separate dishes but how to prepare whole meals. The plan of "Lessons in Cooking" is unique and original in that a systematic course in cooking is taught through a series of menus, with detailed directions, not only for cooking the separate dishes, but also for preparing and serving each meal as $a$ whole. The course is divided into twelve parts, in each of which is given the recipes for a week's menu, typical of one month of the year-over 250 meals in all. In the first lessons, simple operations of cooking are described and gradually the more difficult and complicated recipes are introduced, leading to advanced work in the later lessons. Throughout the course the question of wholesome food combinations and balanced meals is carefully considered and special emphasis is given to economy of time and money.

All available authorities have been consulted and the assistance of a number of prominent teachers of cookery has been obtained in the preparation of this course, which presents the best modern methods and the latest scientific discoveries relating to the "Fine Art of Cooking." 



This book is DUE on the last date stamped below

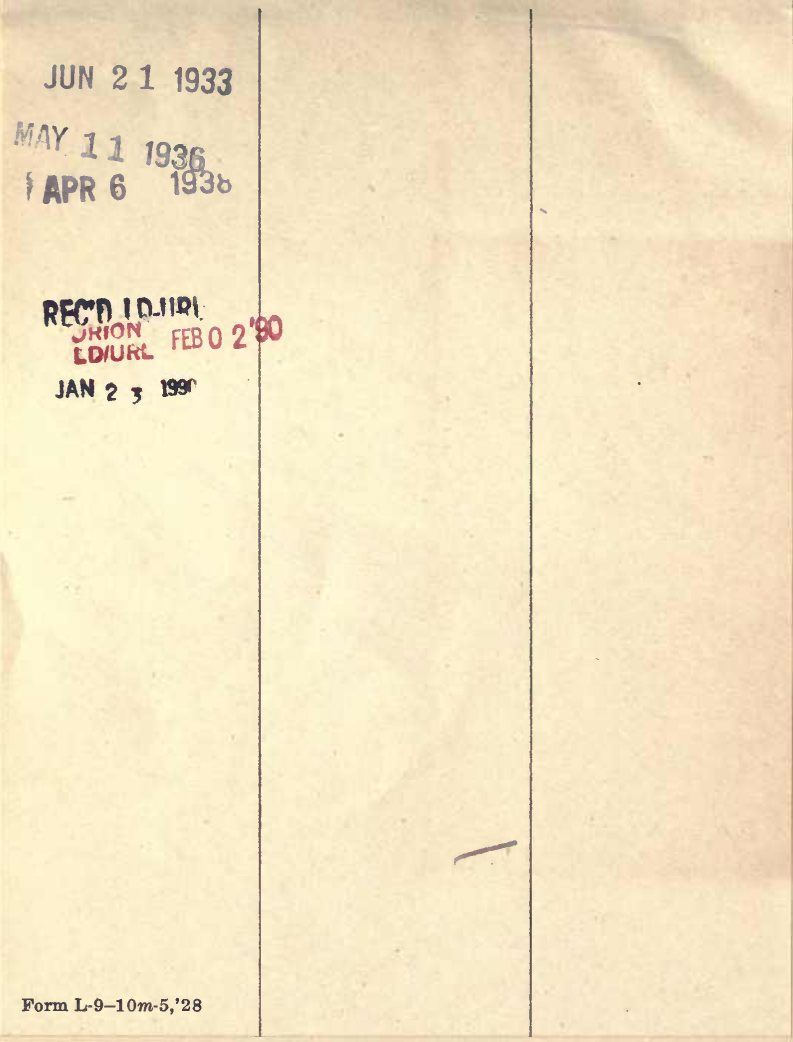


$1.0 \mathrm{C}$ 11E

$L_{0058384538}$

\section{QR56 \\ EA6h}

UC SOUTHERN REGIONAL LIBRARY FACILITY

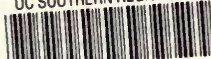

AA $000778433 \quad 3$

\section{MAL SCHOOL}

$\mathrm{S}$, CALIFORNLA

\section{UTVERSITY OF CALIFORNLA AT \\ LOS ANGEI.FS}


